\title{
Carbamoyl Anion Addition to Azirines
}

Michael J. Kerner, ${ }^{\dagger}$ Christian A. Kuttruff, ${ }^{\ddagger}$ Maxim Chevliakov,${ }^{\S}$ Frederic G. Buono, ${ }^{\S}$ Donghong A. Gao," Mariusz Krawiec, 'Carl A. Busacca, ${ }^{\S}$ Chris H. Senanayake, ${ }^{\S}$ Peter Wipf, ${ }^{\dagger}$ and Jonathan T. Reeves*\$

'Department of Chemistry, University of Pittsburgh, Pittsburgh, Pennsylvania 15260, United States \# Medicinal Chemistry, Boehringer Ingelheim Pharma GmbH \& Co KG, 88397 Biberach an der Riss, Germany ${ }^{\S}$ Chemical Development, Boehringer Ingelheim Pharmaceuticals, Inc., Ridgefield, Connecticut 06877, United States "Material and Analytical Sciences, Boehringer Ingelheim Pharmaceuticals, Inc., Ridgefield, Connecticut 06877, United States

*E-mail: jonathan.reeves@ boehringer-ingelheim.com

Supporting Information

\begin{tabular}{|c|l|r|}
\hline I. & General & 1 \\
\hline II. & General Procedure for Carbamoyl Anion Addition & 3 \\
\hline III. & Procedures and Data for All Substrates & $3-16$ \\
\hline IV. & Sample preparation and data collection for X-ray crystal structure of 36 & 17 \\
\hline V. & Thermal ellipsoid plot for 36 & 18 \\
\hline VI. & Crystal data and structure refinement for 36 & 19 \\
\hline VII. & ${ }^{1}$ H and ${ }^{13}$ C NMR Spectra & $20-74$ \\
\hline
\end{tabular}

\section{General Information}

All starting materials and reagents were purchased from commercial sources and used as received unless otherwise noted. ${ }^{1} \mathrm{H}$ and ${ }^{13} \mathrm{C}$ NMR spectra were recorded using Bruker DRX 400 or $500 \mathrm{MHz}$ spectrometers. 
Chemical shifts $(\delta)$ are given in ppm and coupling constants $(J)$ are given in $\mathrm{Hz}$. All ${ }^{1} \mathrm{H}$ and ${ }^{13} \mathrm{C}$ NMR data were referenced to the internal deuterated solvent relative to TMS at $0 \mathrm{ppm}$. High resolution mass spectrometry (HRMS) data were obtained on a Thermo LTQ FT Ultra mass spectrometer at 100,000 resolving power using direct analysis in real time (DART) source ionization in the positive ion mode. Flash chromatography was performed on a Combi-Flash automated system with silica columns. HPLC analysis was performed with a TSK-gel SuperODS column (ID $4.6 \mathrm{~mm}$, length $5.0 \mathrm{~cm}$ ) at $220 \mathrm{~nm}, 10-90 \% \mathrm{MeCN}$ in water over $3.5 \mathrm{~min}$ gradient, and hold at $90 \% \mathrm{MeCN}$ in water for $1.5 \mathrm{~min}$. The enantiomers of racemic 2,3-diphenyl-2H-azirine 1 were separated by preparative SFC (Column: Chiral Technologies, Chiralpak IC, $30 \times 250 \mathrm{~mm}, 5 \mu \mathrm{m}$; part number 83475, conditions: isocratic $5 \%$ isopropanol/ $/ \mathrm{sCO}_{2}$ ). The $\mathrm{SFC}$ fractions in isopropanol were concentrated under reduced pressure at $25{ }^{\circ} \mathrm{C}$ to provide both enantiomers as white solids $\left(\boldsymbol{S}-\mathbf{1},>99 \%\right.$ ee, $\mathrm{t}_{\mathrm{R}}=2.7 \mathrm{~min} ; \boldsymbol{R}-\mathbf{1},>99 \%$ ee, $\left.\mathrm{t}_{\mathrm{R}}=4.0 \mathrm{~min}\right)$.

\section{Compound characterization}

Tabulated ${ }^{1} \mathrm{H}$ and ${ }^{13} \mathrm{C}$ NMR data and copies of ${ }^{1} \mathrm{H}$ and ${ }^{13} \mathrm{C}$ spectra are given for all isolated products. For new compounds, HRMS data is provided. Spectral data obtained for previously reported compounds were in agreement with literature data. The preparation of the following azirines has been reported in the literature and the procedures described for their preparation in the references given for each were followed: $1^{1} ; \mathbf{1 2}^{2} ; \mathbf{1 4}^{3} ; \mathbf{1 6}^{4} ; \mathbf{1 8}^{5} ; \mathbf{2 0}^{6} ; \mathbf{2 6}^{7} ; \mathbf{2 8}^{8}$. Azirines 22 and 24 are new compounds and their preparation, ${ }^{1} \mathrm{H}$ and ${ }^{13} \mathrm{C}$ NMR and HRMS data is described herein. The preparation of the following formamides has been reported in the literature and the procedures described for their preparation in the references given for each were followed: $N$-Methyl- $N$-tert-butylformamide ${ }^{9}$ and $\mathbf{3 4}^{10} . N$-tert-butyl- $N$-(2-((tert-butyldimethylsilyl)oxy)ethyl)formamide and 2,2-dimethyloxazolid-ine-3-carbaldehyde are new compounds and their preparation, ${ }^{1} \mathrm{H}$ and ${ }^{13} \mathrm{C}$ NMR and HRMS data is described herein. All other formamides in Tables 1 and 2 are commercially available and were purchased and used as received. Acetophenone oxime (30) is commercially available and was purchased and used as received.

\footnotetext{
${ }^{1}$ Feng, F.-F.; Li, J.-K.; Liu, X.-Y.; Zhang, F.-G.; Cheung, C. W.; Ma, J.-A. J. Org. Chem. 2020, 85, 10872.

${ }^{2}$ Fitzgerald, R. N.; Jung, D. K.; Eaddy, J. F. Process for the Preparation of Chemical Compounds. PCT. Int. Appl. WO/2001/83479A2, 2001.

${ }^{3}$ Xuan, J.; Xia, X.-D.; Zeng, T.-T.; Feng, Z.-J.; Chen, J.-R.; Lu, L.-Q.; Xiao, W.-J. Angew. Chem. Int. Ed. $2014,53,5653$.

${ }^{4}$ Okamoto, K.; Shimbayashi, T.; Yoshida, M.; Nanya, A.; Ohe, K. Angew. Chem. Int. Ed. 2016, 55, 7199.

${ }^{5}$ Bestmann, H. J.; Kunstmann, R. Chem. Ber. 1969, 102, 1816.

${ }^{6}$ Sato, S. Bull. Chem. Soc. Jpn. 1968, 41, 1440.

${ }^{7}$ Hassner, A.; Fowler, F. W. J. Am. Chem. Soc. 1968, 90, 2869.

${ }^{8}$ Huang, Y.-J.; Qiao, B.; Zhang, F.-G.; Ma, J.-A. Tetrahedron 2018, 74, 3791.

${ }^{9}$ LaPlanche, L. A.; Rogers, M. T. J. Am. Chem. Soc. 1963, 85, 3728.

${ }^{10}$ Reeves, J. T.; Tan, Z.; Herbage, M. H.; Han, Z. S.; Marsini, M. A.; Li, Z.; Li, G.; Xu, Y.; Fandrick, K. R.; Gonnella, N. C.; Campbell, S.; Ma, S.; Grinberg, N.; Lee, H.; Lu, B. Z.; Senanayake, C. H. J. Am. Chem. Soc. 2013, 135, 5565.
} 
Addition of Carbamoyl Anions to Azirine 1. General procedure using $N, N$-diisopropylformamide.

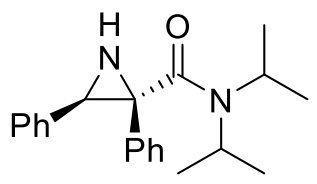

Trans- $N, N$-diisopropyl-2,3-diphenylaziridine-2-carboxamide (2). A reaction flask equipped with a magnetic stir bar was charged with azirine 1 (500 mg, $2.59 \mathrm{mmol}), N, N$-diisopropylformamide $(0.74 \mathrm{~mL}$, $5.44 \mathrm{mmol})$ and anhydrous THF $(5.5 \mathrm{~mL})$ and the resultant solution was cooled to $-78{ }^{\circ} \mathrm{C}$. Then LDA solution (2.60 mL, $5.20 \mathrm{mmol}, 2.0 \mathrm{M}$ solution in THF/heptane/ethylbenzene) was added dropwise. After 30 min, the reaction mixture was quenched with water and allowed to warm to rt. The reaction was diluted with MTBE $(12 \mathrm{~mL})$ and washed with water $(2 \times 12 \mathrm{~mL})$. The organic layer was dried over $\mathrm{Na}_{2} \mathrm{SO}_{4}$, filtered, and concentrated in vacuo. The crude product was purified by chromatography on $\mathrm{SiO}_{2}(25 \%$ MTBE/hexanes) to provide 2 (775 mg, 93\% yield) as a light yellow solid. ${ }^{1} \mathbf{H}$ NMR (400 $\left.\mathbf{M H z}, \mathrm{CDCl}_{3}\right)$ א 7.27-7.24 (m, 2H), 7.19-7.04 (m, 8H), 4.47-4.44 (m, 1H), $3.80(\mathrm{~s}, 1 \mathrm{H}), 3.30-3.23(\mathrm{~m}, 1 \mathrm{H}), 2.52$ (br, 1H), $1.45(\mathrm{~d}, J=6.4 \mathrm{~Hz}, 3 \mathrm{H}), 1.38(\mathrm{~d}, J=6.4 \mathrm{~Hz}, 3 \mathrm{H}), 0.87(\mathrm{~d}, J=6.4 \mathrm{~Hz}, 3 \mathrm{H}), 0.77(\mathrm{~d}, J=6.4 \mathrm{~Hz}, 3 \mathrm{H}) ;{ }^{13} \mathbf{C}$ NMR $\left(100 \mathrm{MHz}, \mathrm{CDCl}_{3}\right) \delta 169.9,136.3,135.5,128.2,127.8(2 \mathrm{C}), 127.7,127.1,127.0,51.6,48.8,45.9$, 44.6, 20.2, 20.0, 19.9 (2C); HRMS (DART) $m / z$ : calcd for $\mathrm{C}_{21} \mathrm{H}_{27} \mathrm{~N}_{2} \mathrm{O}[\mathrm{M}+\mathrm{H}]^{+}$: 323.2118. Found: 323.2119 .

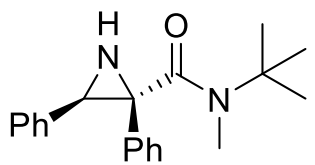

Trans- $N$-(tert-butyl)- $N$-methyl-2,3-diphenylaziridine-2-carboxamide (3). According to the General Procedure, azirine 1 (500 mg, $2.59 \mathrm{mmol}$ ), $N$-tert-butyl- $N$-methylformamide (627 mg, $5.44 \mathrm{mmol}$ ) and LDA solution (2.60 mL, $5.20 \mathrm{mmol}, 2.0 \mathrm{M}$ solution in THF/heptane/ethylbenzene) provided 3 (662 mg, 83\% yield) as a light tan solid after purification by chromatography on $\mathrm{SiO}_{2}\left(25 \% \mathrm{MTBE} /\right.$ hexanes). ${ }^{1} \mathbf{H} \mathbf{N M R}$ $\left(400 \mathrm{MHz}, \mathrm{CDCl}_{3}\right) \delta$ 7.25-7.13 (m, 5H), 7.10 (br s, 5H), 3.72 (s, 1H), 2.86 (s, 3H), $1.38(\mathrm{~s}, 9 \mathrm{H}) ;{ }^{13} \mathbf{C ~ N M R}$ $\left(100 \mathrm{MHz}, \mathrm{CDCl}_{3}\right) \delta 172.3,136.2,135.5,128.6,127.8$ (2C), 127.7, 127.1, 127.0, 56.9, 51.9, 45.4, 32.5, 27.5; HRMS (DART) $m / z$ : calcd for $\mathrm{C}_{20} \mathrm{H}_{25} \mathrm{~N}_{2} \mathrm{O}[\mathrm{M}+\mathrm{H}]^{+}:$309.1961. Found: 309.1963 .

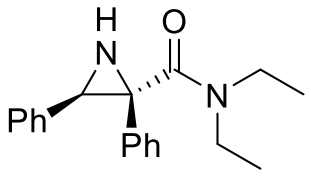


Trans- $N, N$-diethyl-2,3-diphenylaziridine-2-carboxamide (4). According to the General Procedure, azirine 1 (500 mg, $2.59 \mathrm{mmol}), N, N$-diethylformamide $(0.61 \mathrm{~mL}, 5.44 \mathrm{mmol})$ and LDA solution $(2.60 \mathrm{~mL}$, $5.20 \mathrm{mmol}$, 2.0M solution in THF/heptane/ethylbenzene) provided 4 (595 mg, 78\% yield) as an off-white solid after purification by chromatography on $\mathrm{SiO}_{2}$ (25-40\% MTBE/hexanes). ${ }^{\mathbf{1}} \mathbf{H} \mathbf{~ N M R}\left(400 \mathrm{MHz}, \mathrm{CDCl}_{3}\right)$ א 7.26-7.21 (m, 2H), 7.19-7.08 (m, 8H), 3.79 (s, 1H), 3.49-3.31 (m, 4H), 2.51 (br s, 1H), 1.12 (br, 3H), 0.65 (br, 3H); ${ }^{13}$ C NMR (100 MHz, $\left.\mathrm{CDCl}_{3}\right) \delta 170.5,136.2,135.4,128.6,127.9,127.87,127.82,127.2,127.1$, 50.6, 44.9, 41.6, 40.2, 12.9, 12.5; HRMS (DART) $\mathrm{m} / z$ : calcd for $\mathrm{C}_{19} \mathrm{H}_{23} \mathrm{~N}_{2} \mathrm{O}[\mathrm{M}+\mathrm{H}]^{+}:$295.1805. Found: 295.1805 .

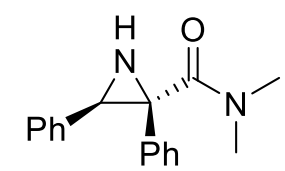

Trans- $N, N$-dimethyl-2,3-diphenylaziridine-2-carboxamide (5). A reaction flask equipped with a magnetic stir bar was charged with 2,2,6,6-tetramethylpiperidine $(1.36 \mathrm{~mL}, 8.03 \mathrm{mmol})$ and THF (3 mL) and the solution was cooled to $-78{ }^{\circ} \mathrm{C}$. $\mathrm{n}$-BuLi $(2.85 \mathrm{~mL}, 2.73 \mathrm{M}$ in hexanes, $7.77 \mathrm{mmol})$ was added dropwise, and the reaction mixture was stirred at $-78^{\circ} \mathrm{C}$ for $30 \mathrm{~min}$, and then allowed to warm to $0{ }^{\circ} \mathrm{C}$. In a separate flask equipped with a magnetic stir bar was charged azirine 1 (500 mg, $2.59 \mathrm{mmol}), N, N$ dimethylformamide $(0.62 \mathrm{~mL}, 8.03 \mathrm{mmol})$ and THF $(3 \mathrm{~mL})$ and the solution was cooled to $-78^{\circ} \mathrm{C}$. The $\mathrm{Li}$ TMP solution from the first flask was then added dropwise via cannula. After $30 \mathrm{~min}$, the reaction mixture was quenched with water and allowed to warm to rt. The reaction was diluted with MTBE (12 mL) and washed with water $\left(2 \times 12 \mathrm{~mL}\right.$ ). The organic layer was dried over $\mathrm{Na}_{2} \mathrm{SO}_{4}$, filtered, and concentrated in vacuo. The crude product was purified by chromatography on $\mathrm{SiO}_{2}\left(0-30 \%\right.$ EtOAc in $\left.\mathrm{CH}_{2} \mathrm{Cl}_{2}\right)$ to provide 5 (543 mg, 79\% yield) as a white solid. ${ }^{1} \mathbf{H}$ NMR $\left(400 \mathrm{MHz}, \mathrm{CDCl}_{3}\right) \delta 7.26-7.10(\mathrm{~m}, 10 \mathrm{H}), 3.81(\mathrm{br}, 1 \mathrm{H})$, 2.95 (s, 6H), 2.42 (br, 1H); $\left.{ }^{13} \mathbf{C ~ N M R ~ ( 1 0 0 ~ M H z , ~} \mathrm{CDCl}_{3}\right) \delta 171.2,135.9,134.8,128.6,127.9,127.8,127.3$, 127.2, 50.5, 45.0, 37.5, 36.1; HRMS (DART) $m / z$ : calcd for $\mathrm{C}_{17} \mathrm{H}_{19} \mathrm{~N}_{2} \mathrm{O}[\mathrm{M}+\mathrm{H}]^{+}:$267.1492. Found: 267.1493.

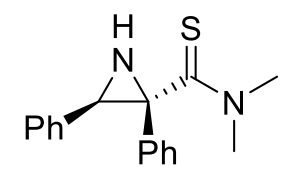

Trans- $N, N$-dimethyl-2,3-diphenylaziridine-2-carbothioamide (6). A reaction flask equipped with a magnetic stir bar was charged with 2,2,6,6-tetramethylpiperidine $(1.36 \mathrm{~mL}, 8.03 \mathrm{mmol})$ and THF (3 mL) 
and the solution was cooled to $-78{ }^{\circ} \mathrm{C}$. $\mathrm{n}$-BuLi $(2.85 \mathrm{~mL}, 2.73 \mathrm{M}$ in hexanes, $7.77 \mathrm{mmol})$ was added dropwise, and the reaction mixture was stirred at $-78{ }^{\circ} \mathrm{C}$ for $30 \mathrm{~min}$, and then allowed to warm to $0{ }^{\circ} \mathrm{C}$. In a separate flask equipped with a magnetic stir bar was charged azirine 1 (500 mg, $2.59 \mathrm{mmol}$ ), N,Ndimethylthioformamide $(0.68 \mathrm{~mL}, 8.03 \mathrm{mmol})$ and THF $(3 \mathrm{~mL})$ and the solution was cooled to $-78^{\circ} \mathrm{C}$. The Li-TMP solution from the first flask was then added dropwise via cannula. After $30 \mathrm{~min}$, the reaction mixture was quenched with water and allowed to warm to rt. The reaction was diluted with MTBE (12 mL) and washed with water $(2 \times 12 \mathrm{~mL})$. The organic layer was dried over $\mathrm{Na}_{2} \mathrm{SO}_{4}$, filtered, and concentrated in vacuo. The crude product was purified by chromatography on $\mathrm{SiO}_{2}\left(75-100 \% \mathrm{CH}_{2} \mathrm{Cl}_{2}\right.$ in hexanes) to provide 6 (519 mg, 71\% yield) as a light yellow solid. ${ }^{1} \mathbf{H} \mathbf{~ N M R}\left(400 \mathrm{MHz}, \mathrm{CDCl}_{3}\right) \delta$ 7.28-7.25 (m, 4H), 7.21-7.14 (m, 3H), 7.12-7.09 (m, 3H), 3.94 (s, 1H), 3.42 (s, 3H), 3.34 (s, 3H), 2.82 (br, 1H); ${ }^{13} \mathbf{C ~ N M R}(100$ $\left.\mathrm{MHz}, \mathrm{CDCl}_{3}\right) \delta 202.8,136.0,135.2,128.8,128.0,127.9,127.5,127.3,54.9,48.0,44.9,42.8$; HRMS (DART) $m / z$ : calcd for $\mathrm{C}_{17} \mathrm{H}_{19} \mathrm{~N}_{2} \mathrm{~S}[\mathrm{M}+\mathrm{H}]^{+}:$283.1264. Found: 283.1264 .

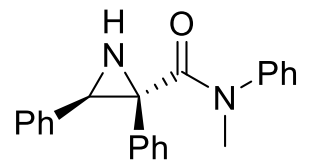

Trans- $N$-methyl- $N, 2,3-t$ triphenylaziridine-2-carboxamide (7). A reaction flask equipped with a magnetic stir bar was charged with 2,2,6,6-tetramethylpiperidine $(1.36 \mathrm{~mL}, 8.03 \mathrm{mmol})$ and THF $(3 \mathrm{~mL})$ and the solution was cooled to $-78{ }^{\circ} \mathrm{C}$. $\mathrm{n}$-BuLi $(2.85 \mathrm{~mL}, 2.73 \mathrm{M}$ in hexanes, $7.77 \mathrm{mmol})$ was added dropwise, and the reaction mixture was stirred at $-78{ }^{\circ} \mathrm{C}$ for $30 \mathrm{~min}$, and then allowed to warm to $0{ }^{\circ} \mathrm{C}$. In a separate flask equipped with a magnetic stir bar was charged azirine 1 (500 mg, $2.59 \mathrm{mmol}), N$-methylformanilide $(0.99$ $\mathrm{mL}, 8.03 \mathrm{mmol})$ and THF $(3 \mathrm{~mL})$ and the solution was cooled to $-78{ }^{\circ} \mathrm{C}$. The Li-TMP solution from the first flask was then added dropwise via cannula. After $30 \mathrm{~min}$, the reaction mixture was quenched with water and allowed to warm to rt. The reaction was diluted with MTBE (12 mL) and washed with water (2 x $12 \mathrm{~mL}$ ). The organic layer was dried over $\mathrm{Na}_{2} \mathrm{SO}_{4}$, filtered, and concentrated in vacuo. The crude product was purified by chromatography on $\mathrm{SiO}_{2}\left(0-10 \% \mathrm{MTBE}\right.$ in $\left.\mathrm{CH}_{2} \mathrm{Cl}_{2}\right)$ to provide 7 (678 $\mathrm{mg}, 80 \%$ yield) as a tan solid. ${ }^{1} \mathbf{H}$ NMR (400 MHz, $\left.\mathrm{CDCl}_{3}\right) \delta 7.13$ (br s, 8H), 6.91-6.88 (m, 1H), 6.82 (br, 2H), 6.77-6.74 (m, 2H), 6.30 (br, 2H), 3.70 (s, 1H), 3.29 (s, 3H), 3.14 (br, 1H); $\left.{ }^{13} \mathbf{C ~ N M R ~ ( 1 0 0 ~ M H z , ~} \mathrm{CDCl}_{3}\right) \delta$ 172.2, 143.1, 136.2, 134.9, 129.4, 129.3, 127.9, 127.8, 127.7, 127.4, 127.3, 127.1, 126.4, 50.1, 45.7, 39.7; HRMS (DART) $m / z$ : calcd for $\mathrm{C}_{22} \mathrm{H}_{21} \mathrm{~N}_{2} \mathrm{O}[\mathrm{M}+\mathrm{H}]^{+}: 329.1648$. Found: 329.1650 .

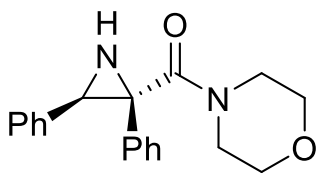


(Trans-2,3-diphenylaziridin-2-yl)(morpholino)methanone (8). According to the General Procedure, azirine 1 (500 mg, $2.59 \mathrm{mmol}), N$-formylmorpholine $(0.55 \mathrm{~mL}, 5.44 \mathrm{mmol})$ and LDA solution (2.60 mL, $5.20 \mathrm{mmol}, 2.0 \mathrm{M}$ solution in THF/heptane/ethylbenzene) provided 8 (507 mg, 63\% yield) as a white solid after purification by chromatography on $\mathrm{SiO}_{2}\left(10-100 \%\right.$ EtOAc/ $\left.\mathrm{CH}_{2} \mathrm{Cl}_{2}\right) .{ }^{1} \mathbf{H}$ NMR $\left(400 \mathrm{MHz}, \mathrm{CDCl}_{3}\right)$

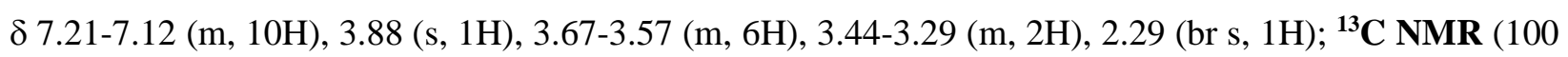
$\left.\mathrm{MHz}, \mathrm{CDCl}_{3}\right) \delta 170.0,135.7,134.8,128.2,128.0,127.9,127.6,127.3,66.5,50.4,46.3,45.0,43.2 ;$ HRMS (DART) $m / z$ : calcd for $\mathrm{C}_{19} \mathrm{H}_{21} \mathrm{~N}_{2} \mathrm{O}_{2}[\mathrm{M}+\mathrm{H}]^{+}:$309.1598. Found: 309.1599 .

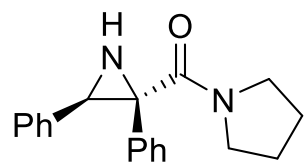

Trans-(2,3-diphenylaziridin-2-yl)(pyrrolidin-1-yl)methanone (9). According to the General Procedure, azirine 1 (500 mg, $2.59 \mathrm{mmol}), \mathrm{N}$-formylpyrrolidine $(0.52 \mathrm{~mL}, 5.44 \mathrm{mmol})$ and LDA solution (2.60 mL, $5.20 \mathrm{mmol}, 2.0 \mathrm{M}$ solution in THF/heptane/ethylbenzene) provided 9 (546 $\mathrm{mg}, 72 \%$ yield) as a light tan solid after purification by chromatography on $\mathrm{SiO}_{2}\left(25 \% \mathrm{MTBE} /\right.$ hexanes). ${ }^{1} \mathbf{H}$ NMR $\left(400 \mathrm{MHz}, \mathrm{CDCl}_{3}\right)$ א 7.20-7.13 (m, 5H), 7.11 (br s, 5H), 3.78 (s, 1H), 3.57-3.44 (m, 2H), 3.28-3.22 (m, 1H), 3.01 (br, 1H), 2.68 (br, 1H), 1.85-1.67 (m, 4H); ${ }^{13} \mathbf{C}$ NMR (100 MHz, $\left.\mathrm{CDCl}_{3}\right) \delta 169.5,136.3,134.7,129.7,127.9,127.8,127.7$, 127.3, 127.1, 50.7, 47.3, 47.2, 44.9, 26.3, 23.7; HRMS (DART) $m / z$ : calcd for $\mathrm{C}_{19} \mathrm{H}_{21} \mathrm{~N}_{2} \mathrm{O}[\mathrm{M}+\mathrm{H}]^{+}$: 293.1648. Found: 293.1650.
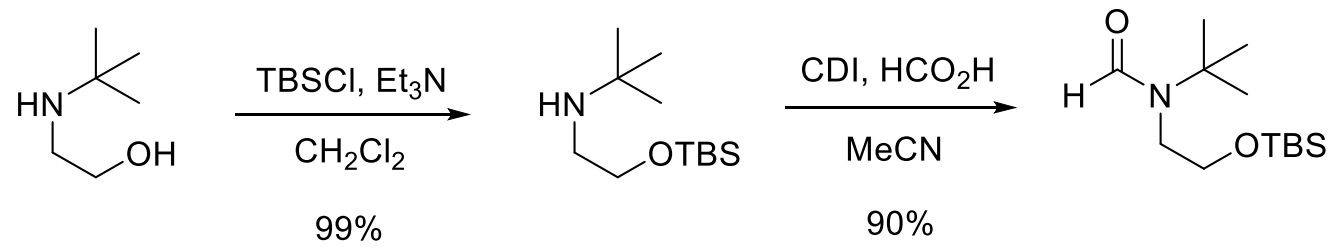

$N$-tert-butyl- $N$-(2-((tert-butyldimethylsilyl)oxy)ethyl)formamide: Step 1: A flask was charged with 2(tert-butylamino)ethan-1-ol (30.0 g, $256.0 \mathrm{mmol}), \mathrm{CH}_{2} \mathrm{Cl}_{2}(200 \mathrm{~mL})$ and $\mathrm{Et}_{3} \mathrm{~N}(53.5 \mathrm{~mL}, 384.0 \mathrm{mmol})$. The resultant solution was treated dropwise at $20-25{ }^{\circ} \mathrm{C}$ with a solution of $\mathrm{TBSCl}(39.4 \mathrm{~g}, 261.1 \mathrm{mmol})$ in $\mathrm{CH}_{2} \mathrm{Cl}_{2}(100 \mathrm{~mL})$. The reaction mixture was stirred at $20-25^{\circ} \mathrm{C}$ for $18 \mathrm{~h}$, and then washed with saturated aqueous $\mathrm{NaHCO}_{3}$ solution and water. The organic phase was dried $\left(\mathrm{Na}_{2} \mathrm{SO}_{4}\right)$, filtered and concentrated to a light brown liquid (61.90 g, 95 wt.\% purity, 99\% yield) which was used directly in the next step. ${ }^{1} \mathbf{H}$ NMR (400 MHz, $\left.\mathrm{CDCl}_{3}\right) \delta 3.66(\mathrm{t}, J=5.5 \mathrm{~Hz}, 2 \mathrm{H}), 2.61(\mathrm{t}, J=5.5 \mathrm{~Hz}, 2 \mathrm{H}), 1.04(\mathrm{~s}, 9 \mathrm{H}), 0.84(\mathrm{~s}, 9 \mathrm{H})$, 0.00 (s, 6H). Step 2: A flask was charged with CDI (53.6 g, $330.3 \mathrm{mmol})$ and MeCN (500 mL). Formic acid $(12.5 \mathrm{~mL}, 330.3 \mathrm{mmol})$ was added dropwise at $20-25^{\circ} \mathrm{C}$. The reaction mixture was stirred at $20-25^{\circ} \mathrm{C}$ 
for $1 \mathrm{~h}$. The crude amino ether prepared in step 1 (61.90 g) was added in one portion to the reaction mixture, using $\mathrm{MeCN}(50 \mathrm{~mL})$ to rinse, and the resultant reaction mixture was stirred at $20-25{ }^{\circ} \mathrm{C}$ for $20 \mathrm{~h}$. The reaction mixture was then concentrated under vacuum to remove most of the $\mathrm{MeCN}$, and the resultant oily residue was taken up in MTBE (400 mL) and the organic phase was washed with water $(4 \times 300 \mathrm{~mL})$. The organic phase was dried $\left(\mathrm{Na}_{2} \mathrm{SO}_{4}\right)$, filtered through a $1 \mathrm{~cm}$ pad of $\mathrm{SiO}_{2}$, and concentrated under reduced pressure at $50-60{ }^{\circ} \mathrm{C}$ to give the product $\left(59.2 \mathrm{~g}, 90 \%\right.$ yield) as a light yellow oil. By ${ }^{1} \mathrm{H} \mathrm{NMR}$ in $\mathrm{CDCl}_{3}$, the compound is a $\sim 94: 6$ mixture of amide rotamers. ${ }^{1} \mathbf{H} \mathbf{~ N M R}\left(400 \mathrm{MHz}, \mathrm{CDCl}_{3}\right.$, major rotamer) $\delta 8.43$ (s, $1 \mathrm{H}), 3.71(\mathrm{t}, J=6.6 \mathrm{~Hz}, 2 \mathrm{H}), 3.42(\mathrm{t}, J=6.6 \mathrm{~Hz}, 2 \mathrm{H}), 1.36(\mathrm{~s}, 9 \mathrm{H}), 0.89(\mathrm{~s}, 9 \mathrm{H}), 0.06(\mathrm{~s}, 6 \mathrm{H}) ;{ }^{13} \mathbf{C ~ N M R}$ $\left(100 \mathrm{MHz}, \mathrm{CDCl}_{3}\right.$, major rotamer) $\delta 161.8,60.9,55.0,43.5,29.7,25.9,18.2,-5.5$; HRMS (DART) $\mathrm{m} / \mathrm{z}$ : calcd for $\mathrm{C}_{13} \mathrm{H}_{30} \mathrm{NO}_{2} \mathrm{Si}[\mathrm{M}+\mathrm{H}]^{+}:$260.2040. Found: 260.2042 .

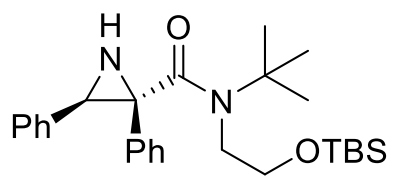

\section{Trans- $N$-(tert-butyl)- $N$-(2-((tert-butyldimethylsilyl)oxy)ethyl)-2,3-diphenylaziridine-2-carboxamide}

(10). According to the General Procedure, azirine 1 (2.00 g, $10.35 \mathrm{mmol}), N$-tert-butyl- $N$-(2-((tertbutyldimethylsilyl)oxy)ethyl)formamide (5.64 g, $21.74 \mathrm{mmol})$, THF (21 mL) and LDA solution (10.4 mL, $20.7 \mathrm{mmol}, 2.0 \mathrm{M}$ solution in THF/heptane/ethylbenzene) provided $\mathbf{1 0}$ (4.36 g, 93\% yield) as a colorless oil after purification by chromatography on $\mathrm{SiO}_{2}$ (10-20\% MTBE/hexanes). ${ }^{1} \mathbf{H}$ NMR $\left(400 \mathrm{MHz}, \mathrm{CDCl}_{3}\right)$ 反 7.27-7.24 (m, 4H), 7.13-7.05 (m, 6H), 3.92-3.90 (m, 1H), 3.81 (br, 1H), 3.66-3.59 (m, 2H), 3.42 (br, 1H), 3.07 (br, 1H), 1.42 (s, 9H), 0.92 (s, 9H), 0.11 (s, 3H), 0.07 (s, 3H); ${ }^{13} \mathbf{C ~ N M R ~ ( 1 0 0 ~ M H z , ~ C D C l ~} 3$ ) $\delta$ 172.6, 136.7, 136.0, 128.1, 127.9, 127.7, 127.6, 127.0, 126.7, 77.4, 62.6, 56.9, 53.0, 46.3, 45.1, 28.6, 26.0, 18.3; HRMS (DART) $m / z$ : calcd for $\mathrm{C}_{27} \mathrm{H}_{41} \mathrm{~N}_{2} \mathrm{O}_{2} \mathrm{Si}[\mathrm{M}+\mathrm{H}]^{+}:$453.2932. Found: 453.2930 .

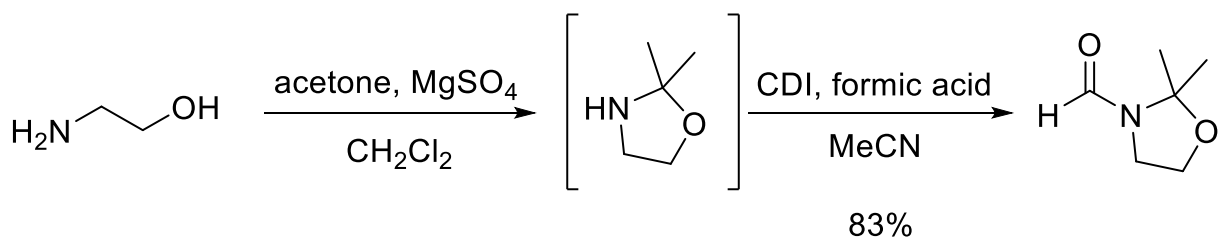

2,2-dimethyloxazolidine-3-carbaldehyde: A flask was charged with $\mathrm{MgSO}_{4}(30.0 \mathrm{~g}, 249.2 \mathrm{mmol}$ ), ethanolamine $(5.0 \mathrm{~mL}, 82.8 \mathrm{mmol}), \mathrm{CH}_{2} \mathrm{Cl}_{2}(150 \mathrm{~mL})$ and acetone $(7.3 \mathrm{~mL}, 99.4 \mathrm{mmol})$. The reaction mixture was stirred at $20-25^{\circ} \mathrm{C}$ for $18 \mathrm{~h}$ and was then filtered and the filtrate concentrated to a light yellow oil which was used immediately in the next step. A separate flask was charged with CDI (20.1 g, 124.2 
mmol) and $\mathrm{MeCN}(140 \mathrm{~mL})$. Formic acid $(4.7 \mathrm{~mL}, 124.2 \mathrm{mmol})$ was added dropwise at $20-25{ }^{\circ} \mathrm{C}$. The reaction mixture was stirred at $20-25{ }^{\circ} \mathrm{C}$ for $1 \mathrm{~h}$. The crude 2,2-dimethyloxazolidine prepared in the first step $(8.60 \mathrm{~g})$ was dissolved in $\mathrm{MeCN}(20 \mathrm{~mL})$ and the resultant solution was added dropwise to the reaction mixture. The reaction mixture was stirred at $20-25{ }^{\circ} \mathrm{C}$ for $46 \mathrm{~h}$. The reaction mixture was concentrated under vacuum to remove most of the $\mathrm{MeCN}$, and the residue was taken up in $\mathrm{CH}_{2} \mathrm{Cl}_{2}(200 \mathrm{~mL})$ and the organic phase was washed with water $(5 \times 200 \mathrm{~mL})$. The organic phase was dried $\left(\mathrm{Na}_{2} \mathrm{SO}_{4}\right)$ and concentrated under reduced pressure at $60{ }^{\circ} \mathrm{C}$ to give the product $(8.88 \mathrm{~g}, 83 \%$ yield $)$ as a pale yellow oil. By ${ }^{1} \mathrm{H}$ NMR in $\mathrm{CDCl}_{3}$, the compound is a 79:21 mixture of amide rotamers. ${ }^{1} \mathbf{H}$ NMR $\left(400 \mathrm{MHz}, \mathrm{CDCl}_{3}\right.$, major rotamer) $\delta 7.96(\mathrm{br}, 1 \mathrm{H}), 3.75(\mathrm{t}, J=6.7 \mathrm{~Hz}, 2 \mathrm{H}), 3.33(\mathrm{td}, J=6.7,1.2 \mathrm{~Hz}, 2 \mathrm{H}), 1.25(\mathrm{~s}, 6 \mathrm{H}) ;{ }^{13} \mathbf{C}$ NMR (100 MHz, $\mathrm{CDCl}_{3}$ ) $\delta 158.2$ (minor), 157.8 (major), 92.8 (minor), 91.5 (major), 63.2 (minor), 62.8 (major), 45.2 (minor), 42.1 (major), 27.2 (major), 24.1 (minor); HRMS (DART) $m / z$ : calcd for $\mathrm{C}_{6} \mathrm{H}_{12} \mathrm{NO}_{2}$ $[\mathrm{M}+\mathrm{H}]^{+}:$130.0863. Found: 130.0866 .

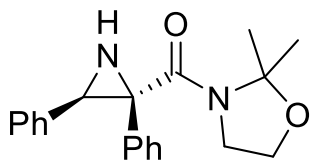

Trans-(2,2-dimethyloxazolidin-3-yl)(2,3-diphenylaziridin-2-yl)methanone (11). According to the General Procedure, azirine 1 (500 mg, $2.59 \mathrm{mmol})$, 2,2-dimethyloxazolidine-3-carbaldehyde (0.70 g, 5.44 $\mathrm{mmol}$ ) and LDA solution (2.60 mL, $5.20 \mathrm{mmol}, 2.0 \mathrm{M}$ solution in THF/heptane/ethylbenzene) provided 11 (670 mg, $80 \%$ yield) as colorless oil after purification by chromatography on $\mathrm{SiO}_{2}(25-40 \%$ MTBE/hexanes). ${ }^{1} \mathbf{H}$ NMR (500 MHz, $\left.\mathrm{CDCl}_{3}\right) \delta$ 7.22-7.11 (m, 10H), 3.87-3.82 (m, 3H), 3.33-3.29 (m, 1H), 3.23-3.18 (m, 1H), 2.57 (d, $J=8.5 \mathrm{~Hz}, 1 \mathrm{H}), 1.61(\mathrm{~s} 3 \mathrm{H}), 1.59$ (s, 3H); ${ }^{13} \mathbf{C} \mathbf{N M R}\left(100 \mathrm{MHz}, \mathrm{CDCl}_{3}\right) \delta$ 167.6, 136.0, 134.3, 129.0, 128.0, 127.9, 127.8, 127.5, 127.2, 95.3, 63.5, 51.6, 46.3, 44.9, 24.4, 23.8; HRMS (DART) $m / z$ : calcd for $\mathrm{C}_{20} \mathrm{H}_{23} \mathrm{~N}_{2} \mathrm{O}_{2}[\mathrm{M}+\mathrm{H}]^{+}:$323.1754. Found: 323.1756.

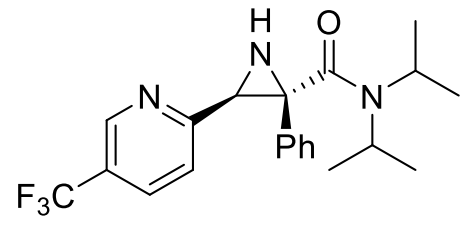


Trans- $N, N$-diisopropyl-2-phenyl-3-(5-(trifluoromethyl)pyridin-2-yl)aziridine-2-carboxamide (13). A reaction flask equipped with a magnetic stir bar was charged with azirine 12 (490 mg, $1.87 \mathrm{mmol}), \mathrm{N}, \mathrm{N}$ diisopropylformamide $(0.38 \mathrm{~mL}, 2.62 \mathrm{mmol})$ and anhydrous THF $(5 \mathrm{~mL})$ and the resultant solution was cooled to $-78^{\circ} \mathrm{C}$. Then LDA solution $(1.31 \mathrm{~mL}, 2.62 \mathrm{mmol}, 2.0 \mathrm{M}$ solution in THF/heptane/ethylbenzene) was added dropwise. After $30 \mathrm{~min}$, the reaction mixture was quenched with water and allowed to warm to rt. The reaction was diluted with MTBE $(12 \mathrm{~mL})$ and washed with water $(2 \times 12 \mathrm{~mL})$. The organic layer was dried over $\mathrm{Na}_{2} \mathrm{SO}_{4}$, filtered, and concentrated in vacuo. The crude product was purified by chromatography on $\mathrm{SiO}_{2}(0-50 \% \mathrm{MTBE} /$ hexanes) to provide $\mathbf{1 3}(490 \mathrm{mg}, 67 \%$ yield) as a light orange solid. ${ }^{1}$ H NMR (400 MHz, $\mathrm{CDCl}_{3}$ ) $\delta 8.68$ (br s, 1H), 7.65 (dd, J = 8.3, 2.0 Hz, 1H), 7.33 (br, 1H), 7.10-7.05 (m, 5H), 4.52-4.49 (m, 1H), 3.92 (s, 1H), 3.30-3.23 (m, 1H), 2.29 (br, 1H), 1.41-1.34 (m, 6H), 0.85 (br, 6H); ${ }^{13}$ C NMR (100 MHz, $\left.\mathrm{CDCl}_{3}\right) \delta 168.8,160.2$ (br), 145.6, 134.4, 132.8 (q, J=3.4 Hz), 128.2, 128.0, 127.5, 124.9 (q, $J=32.8 \mathrm{~Hz}), 123.6$ (q, $J=272 \mathrm{~Hz}), 122.4,52.8,48.9,46.1,45.4,20.1,19.9$; HRMS (DART) $\mathrm{m} / \mathrm{z}$ : calcd for $\mathrm{C}_{21} \mathrm{H}_{25} \mathrm{~F}_{3} \mathrm{~N}_{3} \mathrm{O}[\mathrm{M}+\mathrm{H}]^{+}:$392.1944. Found: 392.1946 .

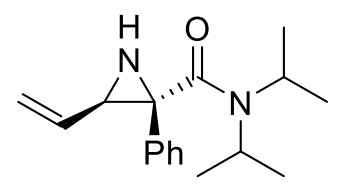

Trans- $N, N$-diisopropyl-2-phenyl-3-vinylaziridine-2-carboxamide (15). A reaction flask equipped with a magnetic stir bar was charged with azirine $14(370 \mathrm{mg}, 2.59 \mathrm{mmol}), N, N$-diisopropylformamide $(0.74 \mathrm{~mL}$, $5.44 \mathrm{mmol})$ and anhydrous THF $(3 \mathrm{~mL})$ and the resultant solution was cooled to $-78^{\circ} \mathrm{C}$. Then LDA solution ( $2.60 \mathrm{~mL}, 5.18 \mathrm{mmol}, 2.0 \mathrm{M}$ solution in THF/heptane/ethylbenzene) was added dropwise. After $30 \mathrm{~min}$, the reaction mixture was quenched with water and allowed to warm to rt. The reaction was diluted with MTBE $(12 \mathrm{~mL})$ and washed with water $(2 \times 12 \mathrm{~mL})$. The organic layer was dried over $\mathrm{Na}_{2} \mathrm{SO}_{4}$, filtered, and concentrated in vacuo. The crude product was purified by chromatography on $\mathrm{SiO}_{2} \quad(25-40 \%$ MTBE/hexanes) to provide 15 (669 mg, 95\% yield) as a colorless oil. ${ }^{1} \mathbf{H} \mathbf{N M R}\left(400 \mathrm{MHz}, \mathrm{CDCl}_{3}\right) \delta 7.45$ $7.43(\mathrm{~m}, 2 \mathrm{H}), 7.33-7.30(\mathrm{~m}, 2 \mathrm{H}), 7.26-7.23(\mathrm{~m}, 1 \mathrm{H}), 5.42-5.39(\mathrm{~m}, 2 \mathrm{H}), 5.14-5.12(\mathrm{~m}, 1 \mathrm{H}), 4.37-4.35(\mathrm{~m}$, 1H), 3.26-3.21 (m, 2H), 2.01 (br, 1H), 1.40-1.36 (m, 6H), 0.88 (br, 3H), 0.69 (br, 3H); ${ }^{13}$ C NMR (100 MHz, $\left.\mathrm{CDCl}_{3}\right) \delta 169.5,136.3,135.1,128.2,127.7,127.4,118.7,48.6,45.8,44.5,20.2,19.8,19.5 ;$ HRMS (DART) $m / z$ : calcd for $\mathrm{C}_{17} \mathrm{H}_{25} \mathrm{~N}_{2} \mathrm{O}[\mathrm{M}+\mathrm{H}]^{+}: 273.1961$. Found: 273.1962 . 


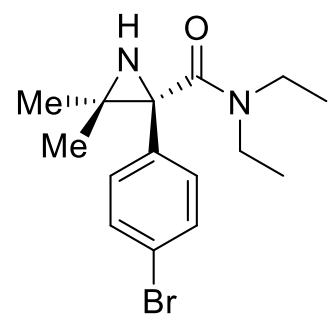

2-(4-Bromophenyl)- $N, N$-diethyl-3,3-dimethylaziridine-2-carboxamide (17). A reaction flask equipped with a magnetic stir bar was charged with azirine 16 (300 mg, $1.34 \mathrm{mmol}), N, N$-diethylformamide $(0.30$ $\mathrm{mL}, 2.68 \mathrm{mmol}$ ) and anhydrous THF (4 mL) and the resultant solution was cooled to $-78{ }^{\circ} \mathrm{C}$. Then LDA solution (1.27 mL, $2.54 \mathrm{mmol}, 2.0 \mathrm{M}$ solution in THF/heptane/ethylbenzene) was added dropwise. After 30 min, the reaction mixture was quenched with water and allowed to warm to rt. The reaction was diluted with MTBE and washed with water twice. The organic layer was dried over $\mathrm{Na}_{2} \mathrm{SO}_{4}$, filtered, and concentrated in vacuo. The crude product was purified by chromatography on $\mathrm{SiO}_{2}(10-30 \%$ MTBE/hexanes) to provide 17 (344 mg, 79\% yield) as a light yellow oil. ${ }^{1} \mathbf{H}$ NMR (400 $\left.\mathbf{M H z}, \mathrm{CDCl}_{3}\right)$

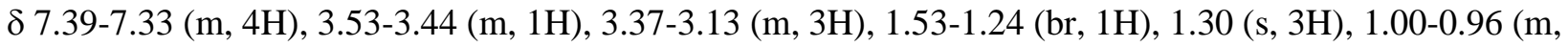
$6 \mathrm{H}), 0.80(\mathrm{t}, J=7.1 \mathrm{~Hz}, 3 \mathrm{H}) ;{ }^{13} \mathrm{C} \mathbf{N M R}\left(100 \mathrm{MHz}, \mathrm{CDCl}_{3}\right) \delta 169.3,136.5,131.3,130.1,121.4,52.5,43.4$, 41.2, 39.4, 24.3, 22.2, 13.6, 12.3; HRMS (DART) $m / z$ : calcd for $\mathrm{C}_{15} \mathrm{H}_{22} \mathrm{BrN}_{2} \mathrm{O}[\mathrm{M}+\mathrm{H}]^{+}:$325.0910. Found: 325.0912 .

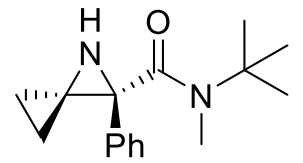

$N$-(tert-butyl)- $N$-methyl-2-phenyl-1-azaspiro[2.2]pentane-2-carboxamide (19). A reaction flask equipped with a magnetic stir bar was charged with $N$-tert-butyl- $N$-methylformamide (603 $\mathrm{mg}, 5.24 \mathrm{mmol}$ ) and anhydrous THF $(8 \mathrm{~mL})$ and the resultant solution was cooled to $-78{ }^{\circ} \mathrm{C}$. Then LDA solution $(2.44 \mathrm{~mL}$, $4.89 \mathrm{mmol}, 2.0 \mathrm{M}$ solution in THF/heptane/ethylbenzene) was added dropwise, followed immediately by a solution of azirine $18(500 \mathrm{mg}, 3.49 \mathrm{mmol})$ in THF ( $2 \mathrm{~mL})$. After $30 \mathrm{~min}$, the reaction mixture was quenched with water and allowed to warm to rt. The reaction was diluted with MTBE (15 mL) and washed with 5\% aqueous $\mathrm{NaHCO}_{3}(2 \times 15 \mathrm{~mL})$. The organic layer was dried over $\mathrm{Na}_{2} \mathrm{CO}_{3}$, filtered, and concentrated in vacuo. The residual oil was chased with hexanes $(2 \times 50 \mathrm{~mL})$ to give a solid, which was triturated with minimal MTBE, filtered, and the solid washed with minimal MTBE and dried under vacuum to provide 19 (606 mg, 67\% yield) as a white solid. ${ }^{1} \mathbf{H}$ NMR (400 MHz, $\left.\mathrm{C}_{6} \mathrm{D}_{6}\right) \delta$ 7.57-7.55 (m, 2H), 7.20-7.15 (m, 2H), 
7.09-7.05 (m, 1H), 2.81 (br s, 1H), 2.19 (s, 3H), 1.30 (s, 9H), 1.10-1.01 (m, 1H), 0.82-0.76 (m, 2H), 0.71$0.62(\mathrm{~m}, 1 \mathrm{H}) ;{ }^{13} \mathrm{C}$ NMR $\left(100 \mathrm{MHz}, \mathrm{C}_{6} \mathrm{D}_{6}\right) \delta 170.9,139.1,128.3,127.1,126.9,56.4,48.1,43.1,31.6,27.3$, 5.3, 3.2; HRMS (DART) $m / z$ : calcd for $\mathrm{C}_{16} \mathrm{H}_{23} \mathrm{~N}_{2} \mathrm{O}[\mathrm{M}+\mathrm{H}]^{+}:$259.1805. Found: 259.1806.

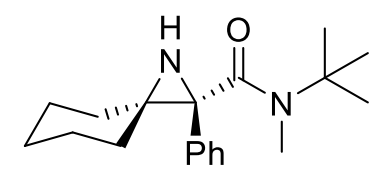

$N$-(tert-butyl)- $N$-methyl-2-phenyl-1-azaspiro[2.5]octane-2-carboxamide (21). A reaction flask equipped with a magnetic stir bar was charged with azirine 20 (1.00 g, $5.40 \mathrm{mmol}), N$-tert-butyl- $N$ methylformamide $(1.31 \mathrm{~g}, 11.3 \mathrm{mmol})$ and anhydrous THF $(15 \mathrm{~mL})$ and the resultant solution was cooled to $-78{ }^{\circ} \mathrm{C}$. Then LDA solution $(5.40 \mathrm{~mL}, 10.8 \mathrm{mmol}, 2.0 \mathrm{M}$ solution in THF/heptane/ethylbenzene) was added dropwise. After $30 \mathrm{~min}$, the reaction mixture was quenched with water and allowed to warm to rt. The reaction was diluted with MTBE $(25 \mathrm{~mL})$ and washed with water $(2 \times 25 \mathrm{~mL})$. The organic layer was dried over $\mathrm{Na}_{2} \mathrm{SO}_{4}$, filtered, and concentrated in vacuo. The crude product was purified by chromatography on $\mathrm{SiO}_{2}$ (10-30\% MTBE/hexanes) to provide 21 (1.32 g, 81\% yield) as a white solid. ${ }^{1} \mathbf{H}$ NMR (400 MHz, $\left.\mathrm{CDCl}_{3}\right) \delta$ 7.57-7.54 (m, 2H), 7.33-7.27 (m, 2H), 7.25-7.21 (m, 1H), $2.94(\mathrm{~s}, 3 \mathrm{H}), 1.88-1.78(\mathrm{~m}, 2 \mathrm{H}), 1.61-$ $1.36(\mathrm{~m}, 8 \mathrm{H}), 1.34$ (s, 9H), 1.17-1.13 (m, 1H); $\left.{ }^{13} \mathbf{C ~ N M R ~ ( 1 0 0 ~ M H z , ~} \mathrm{CDCl}_{3}\right) \delta$ 171.5, 136.9, 128.5, 128.0, 127.0, 56.7, 55.4, 49.0, 33.9, 32.2, 32.0, 27.4, 25.7, 24.8, 24.3; HRMS (DART) $m / z$ : calcd for $\mathrm{C}_{19} \mathrm{H}_{29} \mathrm{~N}_{2} \mathrm{O}$ $[\mathrm{M}+\mathrm{H}]^{+}:$301.2274. Found: 301.2275 .

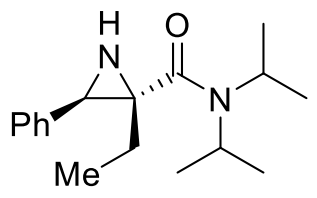

Trans-2-ethyl- $N, N$-diisopropyl-3-phenylaziridine-2-carboxamide (23). A reaction flask equipped with a magnetic stir bar was charged with $N, N$-diisopropylformamide $(1.05 \mathrm{~mL}, 7.23 \mathrm{mmol})$ and anhydrous THF $(8 \mathrm{~mL})$ and the resultant solution was cooled to $-78{ }^{\circ} \mathrm{C}$. Then LDA solution $(3.44 \mathrm{~mL}, 6.89 \mathrm{mmol}, 2.0 \mathrm{M}$ solution in THF/heptane/ethylbenzene) was added dropwise, followed immediately by a solution of azirine 22 (500 mg, $3.44 \mathrm{mmol}$ ) in THF (2 mL). After $30 \mathrm{~min}$, the reaction mixture was quenched with water and allowed to warm to rt. The reaction was diluted with MTBE $(15 \mathrm{~mL})$ and washed with water $(2 \mathrm{x} 15 \mathrm{~mL})$. The organic layer was dried over $\mathrm{Na}_{2} \mathrm{SO}_{4}$, filtered, and concentrated in vacuo. The crude product was purified by chromatography on $\mathrm{SiO}_{2}(25 \% \mathrm{MTBE} / \mathrm{h}$ exanes) to provide $\mathbf{2 3}$ (739 mg, $78 \%$ yield) as a light yellow oil. ${ }^{1} \mathbf{H}$ NMR $\left(400\right.$ MHz, $\left.\mathrm{CDCl}_{3}\right) \delta$ 7.36-7.31 (m, 4H), 7.30-7.24 (m, 1H), 4.33-4.24 (m, 1H), 3.46- 
$3.36(\mathrm{~m}, 1 \mathrm{H}), 3.24(\mathrm{~s}, 1 \mathrm{H}), 2.15(\mathrm{br} \mathrm{s}, 1 \mathrm{H}), 1.48-1.41(\mathrm{~m}, 7 \mathrm{H}), 1.34(\mathrm{~d}, J=6.7 \mathrm{~Hz}, 3 \mathrm{H}), 1.21$ (d, $J=6.7 \mathrm{~Hz}$, 3H), 1.13-1.00 (m, 4H); ${ }^{13} \mathbf{C}$ NMR (100 MHz, $\left.\mathrm{CDCl}_{3}\right) \delta 171.4,136.5,128.2,127.3,127.2,49.1,48.8,45.8$, 42.7, 22.4, 21.04, 21.00, 20.2, 20.0, 10.2; HRMS (DART) $m / z$ : calcd for $\mathrm{C}_{17} \mathrm{H}_{27} \mathrm{~N}_{2} \mathrm{O}[\mathrm{M}+\mathrm{H}]^{+}: 275.2118$. Found: 275.2120 .

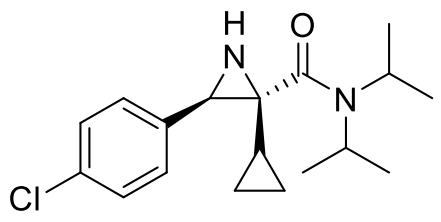

Trans-3-(4-chlorophenyl)-2-cyclopropyl- $N, N$-diisopropylaziridine-2-carboxamide (25). A reaction flask equipped with a magnetic stir bar was charged with $N, N$-diisopropylformamide $(0.80 \mathrm{~mL}, 5.48 \mathrm{mmol})$ and anhydrous THF $(8 \mathrm{~mL})$ and the resultant solution was cooled to $-78{ }^{\circ} \mathrm{C}$. Then LDA solution $(2.61 \mathrm{~mL}$, $5.22 \mathrm{mmol}, 2.0 \mathrm{M}$ solution in THF/heptane/ethylbenzene) was added dropwise, followed immediately by a solution of azirine $\mathbf{2 4}(500 \mathrm{mg}, 2.61 \mathrm{mmol})$ in THF ( $2 \mathrm{~mL})$. After $30 \mathrm{~min}$, the reaction mixture was quenched with water and allowed to warm to rt. The reaction was diluted with MTBE (15 mL) and washed with water $(2 \times 15 \mathrm{~mL})$. The organic layer was dried over $\mathrm{Na}_{2} \mathrm{SO}_{4}$, filtered, and concentrated in vacuo. The crude product was purified by chromatography on $\mathrm{SiO}_{2}$ (15\% MTBE/hexanes) to provide 25 (711 $\mathrm{mg}, 85 \%$ yield) as an off-white solid. ${ }^{1} \mathbf{H}$ NMR $\left(400 \mathrm{MHz}, \mathrm{CDCl}_{3}\right) \delta 7.31(\mathrm{~s}, 4 \mathrm{H}), 4.41-4.34(\mathrm{~m}, 1 \mathrm{H}), 3.46-3.40(\mathrm{~m}, 1 \mathrm{H})$, $3.18(\mathrm{~d}, J=9.5 \mathrm{~Hz}, 1 \mathrm{H}), 2.16(\mathrm{~d}, J=9.5 \mathrm{~Hz}, 1 \mathrm{H}), 1.47-1.40(\mathrm{~m}, 6 \mathrm{H}), 1.32(\mathrm{~d}, J=6.7 \mathrm{~Hz}, 3 \mathrm{H}), 1.25(\mathrm{~d}, J=$ $6.7 \mathrm{~Hz}, 3 \mathrm{H}), 0.84-0.78(\mathrm{~m}, 1 \mathrm{H}), 0.63-0.57(\mathrm{~m}, 1 \mathrm{H}), 0.54-0.43(\mathrm{~m}, 2 \mathrm{H}), 0.40-0.33(\mathrm{~m}, 1 \mathrm{H}) ;{ }^{13} \mathbf{C}$ NMR $(100$ $\left.\mathrm{MHz}_{\mathrm{CDCl}}\right) \delta 171.2,135.3,132.8,128.9,128.3,128.2,49.0,48.6,45.7,42.6,21.1,20.9,20.1,19.9,10.4$, 6.2, 3.8; HRMS (DART) $m / z$ : calcd for $\mathrm{C}_{18} \mathrm{H}_{26} \mathrm{ClN}_{2} \mathrm{O}[\mathrm{M}+\mathrm{H}]^{+}:$321.1728. Found: 321.1731 .

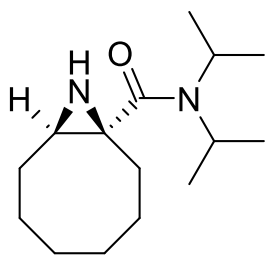

Trans- $N, N$-diisopropyl-9-azabicyclo[6.1.0]nonane-1-carboxamide (27). A reaction flask equipped with a magnetic stir bar was charged with $N, N$-diisopropylformamide $(1.24 \mathrm{~mL}, 8.52 \mathrm{mmol})$ and anhydrous THF $(13 \mathrm{~mL})$ and the resultant solution was cooled to $-78^{\circ} \mathrm{C}$. Then LDA solution $(4.06 \mathrm{~mL}, 8.12 \mathrm{mmol}, 2.0 \mathrm{M}$ solution in THF/heptane/ethylbenzene) was added dropwise, followed immediately by a solution of azirine 26 (500 mg, $4.06 \mathrm{mmol}$ ) in THF (2 mL). After $30 \mathrm{~min}$, the reaction mixture was quenched with water and allowed to warm to rt. The reaction was diluted with MTBE $(20 \mathrm{~mL})$ and washed with water $(2 \times 20 \mathrm{~mL})$. The organic layer was dried over $\mathrm{Na}_{2} \mathrm{SO}_{4}$, filtered, and concentrated in vacuo. The crude product was 
purified by chromatography on $\mathrm{SiO}_{2}(25-60 \%$ MTBE/hexanes) to provide 27 (934 $\mathrm{mg}, 91 \%$ yield) as a white solid. ${ }^{1} \mathbf{H}$ NMR (400 MHz, $\mathrm{CDCl}_{3}$ ) $\delta$ 4.46-4.43 (m, 1H), 3.25-3.22 (m, 1H), 2.23 (br, 1H), 2.09-2.01 (m, 2H), 1.93-1.76 (m, 2H), 1.52-1.43 (m, 4H), 1.40-1.20 (m, 9H), 1.16-1.09 (m, 6H), 1.04-0.94 (m, 1H), 0.62 (br, $1 \mathrm{H}) ;{ }^{13} \mathbf{C} \mathbf{N M R}\left(100 \mathrm{MHz}, \mathrm{CDCl}_{3}\right) \delta 169.9,47.9,45.8,45.4,40.2,29.9,28.5,26.8,26.14,26.08$, 25.7, 20.8, 20.6, 20.5, 20.1; HRMS (DART) $m / z$ : calcd for $\mathrm{C}_{15} \mathrm{H}_{29} \mathrm{~N}_{2} \mathrm{O}[\mathrm{M}+\mathrm{H}]^{+}$: 253.2274. Found: 253.2275 .

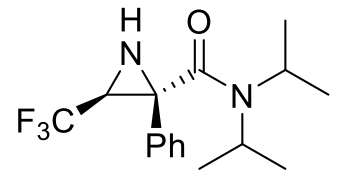

Trans- $N, N$-diisopropyl-2-phenyl-3-(trifluoromethyl)aziridine-2-carboxamide (29). A reaction flask equipped with a magnetic stir bar was charged with azirine 28 (500 mg, $2.70 \mathrm{mmol}$ ), N,Ndiisopropylformamide $(0.82 \mathrm{~mL}, 5.67 \mathrm{mmol})$ and anhydrous THF $(10 \mathrm{~mL})$ and the resultant solution was cooled to $-78{ }^{\circ} \mathrm{C}$. Then LDA solution $(2.70 \mathrm{~mL}, 5.40 \mathrm{mmol}, 2.0 \mathrm{M}$ solution in THF/heptane/ethylbenzene) was added dropwise. After $30 \mathrm{~min}$, the reaction mixture was quenched with water and allowed to warm to rt. The reaction was diluted with MTBE $(15 \mathrm{~mL})$ and washed with water $(2 \times 15 \mathrm{~mL})$. The organic layer was dried over $\mathrm{Na}_{2} \mathrm{SO}_{4}$, filtered, and concentrated in vacuo. The crude product was purified by chromatography on $\mathrm{SiO}_{2}$ (0-25\% MTBE/hexanes) to provide 29 (528 $\mathrm{mg}, 62 \%$ yield) as a light yellow solid. ${ }^{1} \mathbf{H}$ NMR $\left(400 \mathrm{MHz}, \mathrm{CDCl}_{3}\right) \delta$ 7.52-7.50 (m, 2H), 7.36-7.28 (m, 3H), 4.34-4.28 (m, 1H), 3.36-3.33 (m, 1H), 3.27-3.21 (m, 1H), $2.22(\mathrm{~d}, J=9.9 \mathrm{~Hz}, 1 \mathrm{H}), 1.37-1.33(\mathrm{~m}, 6 \mathrm{H}), 0.95-0.94(\mathrm{~m}, 3 \mathrm{H}), 0.60(\mathrm{~d}, J=5.8 \mathrm{~Hz}, 3 \mathrm{H})$; ${ }^{13} \mathrm{C}$ NMR $\left(100 \mathrm{MHz}, \mathrm{CDCl}_{3}\right) \delta 167.2,133.1,128.3,128.1,127.8,123.7$ (q, J = $\left.275 \mathrm{~Hz}\right), 49.3,48.8,46.2$, 41.1 (q, $J=39 \mathrm{~Hz}$ ), 20.2, 20.1, 19.5, 19.2; HRMS (DART) $m / z$ : calcd for $\mathrm{C}_{16} \mathrm{H}_{22} \mathrm{~F}_{3} \mathrm{~N}_{2} \mathrm{O}[\mathrm{M}+\mathrm{H}]^{+}: 315.1679$. Found: 315.1681 .

Procedures for preparation of new azirines used in Table 2.

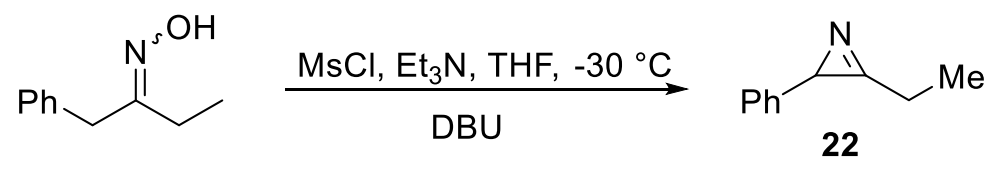


3-Ethyl-2-phenyl-2H-azirine (22). A reaction flask equipped with a magnetic stir bar was charged with 1phenylbutan-2-one oxime ${ }^{11}(10.0 \mathrm{~g}, 61.3 \mathrm{mmol})$ and anhydrous THF $(150 \mathrm{~mL})$. The solution was cooled to $-30{ }^{\circ} \mathrm{C}$ and was treated with $\mathrm{MsCl}(5.69 \mathrm{~mL}, 73.5 \mathrm{mmol})$ followed by dropwise addition of $\mathrm{Et}_{3} \mathrm{~N}(10.3 \mathrm{~mL}$, $73.5 \mathrm{mmol})$ at a rate to control the temperature between -30 to $-25^{\circ} \mathrm{C}$. After $30 \mathrm{~min}$, DBU $(27.5 \mathrm{~mL}, 183.8$ mmol) was added dropwise. The reaction mixture was allowed to warm to $20{ }^{\circ} \mathrm{C}$ and stirred at this temperature for $30 \mathrm{~min}$. The reaction mixture was quenched with water and diluted with MTBE and the layers were separated. The organic phase was washed with water twice more and then dried over $\mathrm{Na}_{2} \mathrm{SO}_{4}$, filtered, and concentrated. The crude product was purified by chromatography on $\mathrm{SiO}_{2} \quad(90: 10$ hexanes/MTBE) to provide the title compound $\left(6.70 \mathrm{~g}, 75 \%\right.$ yield) as a light yellow oil. ${ }^{1} \mathbf{H}$ NMR (400

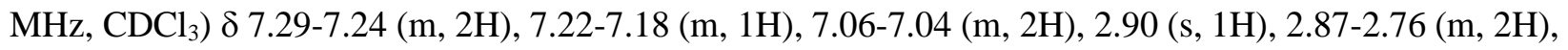
$1.32(\mathrm{t}, J=7.5 \mathrm{~Hz}, 3 \mathrm{H}) ;{ }^{13} \mathbf{C} \mathbf{N M R}\left(100 \mathrm{MHz}, \mathrm{CDCl}_{3}\right) \delta 168.2,141.6,128.2,126.7,125.6,34.0,20.8,8.7$; HRMS (DART) $m / z$ : calcd for $\mathrm{C}_{10} \mathrm{H}_{12} \mathrm{~N}[\mathrm{M}+\mathrm{H}]^{+}:$146.0964. Found: 146.0965 .

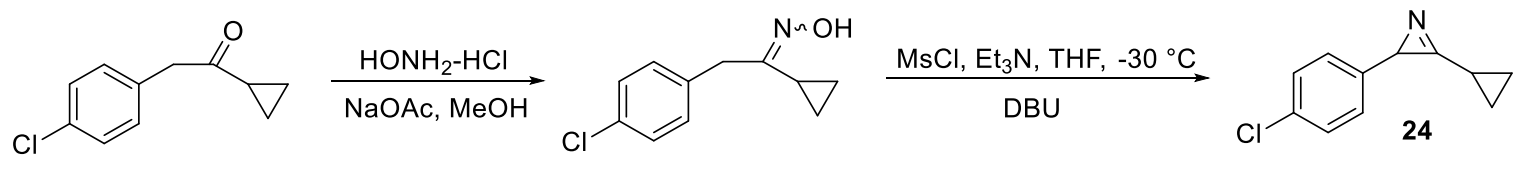

3-(4-Chlorophenyl)-2-cyclopropyl-2H-azirine (24). A reaction flask equipped with a magnetic stir bar was charged with 2-(4-chlorophenyl)-1-cyclopropylethan-1-one ${ }^{12}(10.0 \mathrm{~g}, 51.4 \mathrm{mmol})$, hydroxylamine hydrochloride $(7.14 \mathrm{~g}, 102.7 \mathrm{mmol})$, sodium acetate $(8.43 \mathrm{~g}, 102.7 \mathrm{mmol})$ and $\mathrm{MeOH}(100 \mathrm{~mL})$. The reaction mixture was stirred at $\mathrm{rt}$ for $18 \mathrm{~h}$, and then diluted with water and extracted with MTBE. The organic phase was washed with water followed by saturated aqueous $\mathrm{NaHCO}_{3}$ and then dried over $\mathrm{Na}_{2} \mathrm{SO}_{4}$, filtered, and concentrated. The crude product was purified by chromatography on $\mathrm{SiO}_{2} \quad(80: 20$ hexanes/MTBE) to provide 2-(4-chlorophenyl)-1-cyclopropylethan-1-one oxime (7.66 g, 71\% yield) as a light yellow oil and a 2:1 mixture of oxime geometric isomers. ${ }^{1} \mathbf{H}$ NMR $\left(400 \mathrm{MHz}, \mathrm{CDCl}_{3}\right) \delta 9.82-9.65$ (br, 1H), 7.25-7.21 (m, 2H), 7.19-7.11 (m, 2H), 3.64 (s, 1.33H, major isomer), 3.19 (s, 0.69H, minor isomer), 2.35-2.28 (m, 0.34H, minor isomer), 1.48-1.41 (m, 0.67H, major isomer), 0.82-0.77 (m, 0.66H), 0.68-0.63 $(\mathrm{m}, 3.29 \mathrm{H}) ;{ }^{13} \mathrm{C}$ NMR $\left(100 \mathrm{MHz}, \mathrm{CDCl}_{3}\right) \delta 160.1,135.7,135.3,132.5,132.2,130.4,130.0,128.7,128.6$, 35.3, 32.8, 14.3, 9.1, 5.8, 5.6; HRMS (DART) $m / z$ : calcd for $\mathrm{C}_{11} \mathrm{H}_{13} \mathrm{ClNO}[\mathrm{M}+\mathrm{H}]^{+}:$: 210.0680. Found: 210.0682. The oxime $(7.40 \mathrm{~g}, 35.3 \mathrm{mmol})$ was dissolved in THF $(150 \mathrm{~mL})$ and the solution cooled to -30

\footnotetext{
${ }^{11}$ Gonzalez-Sabin, J.; Rios-Lombardia, N.; Garcia, I.; Vior, N. M.; Brana, A. F.; Mendez, C.; Salas, J. A.; Moris, F. Green Chem. 2016, 18, 989.

12 Razus, A. C.; Bartha, E.; Arvay, Z.; Glatz, A.-M. Rev. Roum. Chim. 1984, 29, 719.
} 
${ }^{\circ} \mathrm{C} . \mathrm{Et}_{3} \mathrm{~N}(5.90 \mathrm{~mL}, 42.4 \mathrm{mmol})$ was added followed by dropwise addition of $\mathrm{MsCl}(3.28 \mathrm{~mL}, 42.4 \mathrm{mmol})$. The reaction mixture was stirred at $-30{ }^{\circ} \mathrm{C}$ for $30 \mathrm{~min}$, and then $\mathrm{DBU}(15.8 \mathrm{~mL}, 105.9 \mathrm{mmol})$ was added dropwise. The reaction mixture was allowed to warm to $\mathrm{rt}$ over $1 \mathrm{~h}$ and was then diluted with MTBE and washed with water twice. The organic phase was dried $\left(\mathrm{Na}_{2} \mathrm{SO}_{4}\right)$, filtered, and concentrated. The crude product was purified by chromatography on $\mathrm{SiO}_{2}$ (95:5 to 90:10 hexanes/MTBE) to provide 24 (6.18 g, $91 \%$ yield) as a light yellow oil. ${ }^{1} \mathbf{H}$ NMR (400 MHz, $\left.\mathrm{CDCl}_{3}\right) \delta$ 7.24-7.21 (m, 2H), 7.01-6.98 (m, 2H), 2.79 (s, $1 \mathrm{H}), 2.19-2.13(\mathrm{~m}, 1 \mathrm{H}), 1.23-1.08(\mathrm{~m}, 3 \mathrm{H}), 0.82-0.77(\mathrm{~m}, 1 \mathrm{H}) ;{ }^{13} \mathbf{C ~ N M R}\left(100 \mathrm{MHz}, \mathrm{CDCl}_{3}\right) \delta 168.3,140.1$, 132.3, 128.3, 126.8, 32.2, 8.3, 7.4, 7.35; HRMS (DART) $\mathrm{m} / \mathrm{z}$ : calcd for $\mathrm{C}_{11} \mathrm{H}_{11} \mathrm{ClN}[\mathrm{M}+\mathrm{H}]^{+}: 192.0575$. Found: 192.0575.

\section{Procedure for one-pot oxime tosylation, azirine formation and carbamoyl anion addition:}

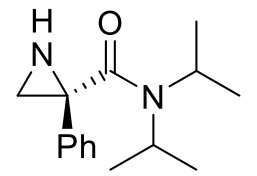

$N, N$-Diisopropyl-2-phenylaziridine-2-carboxamide (33). A reaction flask equipped with a magnetic stir bar was charged with sodium hydride (710 mg, $17.8 \mathrm{mmol}, 60 \mathrm{wt} . \%)$ and THF (20 mL). Acetophenone oxime $(2.00 \mathrm{~g}, 14.8 \mathrm{mmol})$ was then added portionwise at $\mathrm{rt}$. The reaction mixture was stirred at $\mathrm{rt}$ for 30 min, and then cooled to $0{ }^{\circ} \mathrm{C}$. $\mathrm{TsCl}(2.96 \mathrm{~g}, 15.5 \mathrm{mmol})$ was added portionwise and the reaction mixture was stirred at $0{ }^{\circ} \mathrm{C}$ for $30 \mathrm{~min}$. The solution was cooled to $-78{ }^{\circ} \mathrm{C}$ and was treated with $N, N$ diisopropylformamide (3.22 mL, $22.2 \mathrm{mmol})$ followed by dropwise addition of LDA (17.8 mL, $35.5 \mathrm{mmol}$, $2.0 \mathrm{M}$ solution in THF/heptane/ethylbenzene). After $30 \mathrm{~min}$, the reaction mixture was quenched with water and diluted with MTBE and the layers were separated. The organic phase was washed with water and then dried over $\mathrm{Na}_{2} \mathrm{SO}_{4}$, filtered, and concentrated. The crude product was purified by chromatography on $\mathrm{SiO}_{2}$ (70:30 to 50:50 hexanes/MTBE) to provide the title compound (1.97 g, 54\% yield) as a light brown oil. ${ }^{1} \mathbf{H}$ NMR $\left(400 \mathrm{MHz}, \mathrm{CDCl}_{3}\right) \delta$ 7.32-7.28 (m, 4H), 7.27-7.21 (m, 1H), 4.28-4.22 (m, 1H), 3.33-3.26 (m, 1H), $2.30(\mathrm{~d}, J=10.8 \mathrm{~Hz}, 2 \mathrm{H}), 2.04(\mathrm{br}, 1 \mathrm{H}), 1.45-1.41(\mathrm{~m}, 6 \mathrm{H}), 0.95(\mathrm{~d}, J=6.1 \mathrm{~Hz}, 3 \mathrm{H}), 0.63(\mathrm{br}, 3 \mathrm{H}) ;{ }^{13} \mathbf{C}$ NMR $\left(100 \mathrm{MHz}, \mathrm{CDCl}_{3}\right) \delta 169.7,138.6,128.6,127.4,126.5,49.0,45.8,31.0,20.4,20.2,19.6,19.0$; HRMS (DART) $m / z$ : calcd for $\mathrm{C}_{15} \mathrm{H}_{23} \mathrm{~N}_{2} \mathrm{O}[\mathrm{M}+\mathrm{H}]^{+}:$247.1805. Found: 247.1806. 


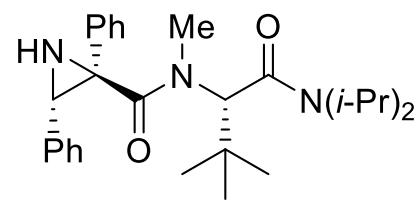

\section{(2R,3S)- $N-((S)-1-($ diisopropylamino)-3,3-dimethyl-1-oxobutan-2-yl)- $N$-methyl-2,3-}

diphenylaziridine-2-carboxamide (35). A reaction flask equipped with a magnetic stir bar was charged with ( $S$ )- $N, N$-diisopropyl-3,3-dimethyl-2-( $N$-methylformamido)butanamide $34^{9}$ (930 mg, $3.62 \mathrm{mmol}$ ), $S$-1 (500 mg, $2.59 \mathrm{mmol})$ and anhydrous THF $(10 \mathrm{~mL})$ and the resultant solution was cooled to $-78{ }^{\circ} \mathrm{C}$. Then LDA solution (1.81 mL, $3.62 \mathrm{mmol}, 2.0 \mathrm{M}$ solution in THF/heptane/ethylbenzene) was added dropwise. After $30 \mathrm{~min}$, the reaction mixture was quenched with water and allowed to warm to rt. The reaction was diluted with MTBE (12 mL) and washed with water $(2 \times 12 \mathrm{~mL})$. The organic layer was dried over $\mathrm{Na}_{2} \mathrm{SO}_{4}$, filtered, and concentrated in vacuo to a light yellow solid, which appeared to be a single diastereomer by ${ }^{1} \mathrm{H}$ NMR. The crude product was purified by crystallization from MTBE/hexanes to provide 35 (806 mg, $69 \%$ yield) as a white solid. ${ }^{1} \mathbf{H}$ NMR $\left(400 \mathrm{MHz}, \mathrm{CDCl}_{3}\right) \delta 7.18-7.11(\mathrm{~m}, 10 \mathrm{H}), 5.17(\mathrm{~s}, 1 \mathrm{H}), 4.06-4.03(\mathrm{~m}$, 1H), 3.85 (s, 1H), 3.33-3.27 (m, 1H), 3.09 (s, 3H), 2.28 (br, 1H), 1.38 (d, J = 6.7 Hz, 3H), 1.30-1.29 (m, $3 \mathrm{H}), 1.16(\mathrm{~d}, J=6.7 \mathrm{~Hz}, 3 \mathrm{H}), 1.05(\mathrm{~s}, 9 \mathrm{H}), 0.88(\mathrm{br}, 3 \mathrm{H}) ;{ }^{13} \mathbf{C ~ N M R}\left(100 \mathrm{MHz}, \mathrm{CDCl}_{3}\right) \delta 171.8,168.1$, 135.6, 134.0, 129.0, 127.8, 127.7, 127.5, 127.2, 59.4, 51.3, 48.3, 46.0, 45.0, 37.5, 33.8, 28.0, 21.0, 20.5, 20.4; HRMS (DART) $m / z$ : calcd for $\mathrm{C}_{28} \mathrm{H}_{40} \mathrm{~N}_{3} \mathrm{O}_{2}[\mathrm{M}+\mathrm{H}]^{+}: 450.3115$. Found: 450.3118 .

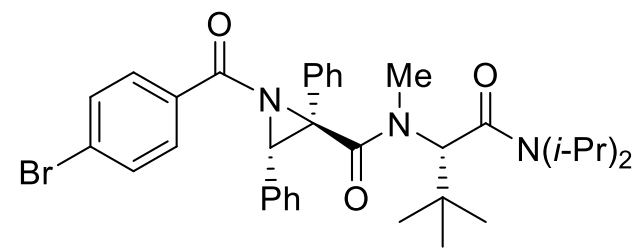

(2R,3S)-1-(4-bromobenzoyl)- $N$-((S)-1-(diisopropylamino)-3,3-dimethyl-1-oxobutan-2-yl)- $N$-methyl-

2,3-diphenylaziridine-2-carboxamide (36). A reaction flask equipped with a magnetic stir bar was charged with 35 (300 mg, $0.67 \mathrm{mmol}$ ), 4-bromobenzoyl chloride (176 mg, $0.80 \mathrm{mmol}$ ) and MeCN (3.0 mL). $\mathrm{Et}_{3} \mathrm{~N}(0.19 \mathrm{~mL}, 1.33 \mathrm{mmol})$ was added and the reaction mixture was stirred at $\mathrm{rt}$ for $16 \mathrm{~h}$. Water $(6 \mathrm{~mL})$ was added and the resultant slurry stirred at $\mathrm{rt}$ for $30 \mathrm{~min}$, filtered, and the solid washed with water and dried under vacuum at $55^{\circ} \mathrm{C}$. The crude solid was recrystallized by heating in $\mathrm{MeOH}$ to reflux to obtain a solution and then allowing the solution to cool gradually to rt and sit at rt for 3 days. The crystals were filtered, washed with cold $\mathrm{MeOH}$ and dried under vacuum at $55{ }^{\circ} \mathrm{C}$ to provide 36 (347 $\mathrm{mg}, 82 \%$ yield) as a white solid. ${ }^{1} \mathbf{H}$ NMR $\left(400 \mathrm{MHz}, \mathrm{CDCl}_{3}\right) \delta 7.80(\mathrm{~d}, J=7.9 \mathrm{~Hz}, 2 \mathrm{H}), 7.48(\mathrm{~d}, J=7.9 \mathrm{~Hz}, 2 \mathrm{H}), 7.29-7.13(\mathrm{~m}, 10 \mathrm{H})$, 
$5.32(\mathrm{~s}, 1 \mathrm{H}), 4.91(\mathrm{~s}, 1 \mathrm{H}), 4.35-4.33(\mathrm{~m}, 1 \mathrm{H}), 3.44-3.42(\mathrm{~m}, 1 \mathrm{H}), 3.03(\mathrm{~s}, 3 \mathrm{H}), 1.50(\mathrm{~d}, J=6.1 \mathrm{~Hz}, 3 \mathrm{H}), 1.42$ $(\mathrm{d}, J=6.1 \mathrm{~Hz}, 3 \mathrm{H}), 1.18-1.14(\mathrm{~m}, 6 \mathrm{H}), 1.01(\mathrm{~s}, 9 \mathrm{H}) ;{ }^{13} \mathbf{C}$ NMR $\left(100 \mathrm{MHz}, \mathrm{CDCl}_{3}\right) \delta 175.9,169.0,168.3$, 134.1, 133.0, 131.8, 131.7, 130.4, 128.6, 128.0, 127.97, 127.9, 127.8, 127.5, 59.7, 58.8, 52.0, 48.6, 46.1, 37.6, 35.3, 27.9, 21.1, 20.9, 20.7, 20.4; HRMS (DART) $m / z$ : calcd for $\mathrm{C}_{35} \mathrm{H}_{43} \mathrm{BrN}_{3} \mathrm{O}_{3}[\mathrm{M}+\mathrm{H}]^{+}: 632.2482$. Found: 632.2485 .

\section{X-ray crystal structure determination of 36:}

Crystals were prepared by heating $400 \mathrm{mg}$ of crude $36 \mathrm{in} \mathrm{MeOH}(4 \mathrm{~mL})$ to $65^{\circ} \mathrm{C}$ to obtain a solution and removing the heat and allowing the solution to cool to ambient temperature and remain at this temperature for 3 days. The crystals were filtered and washed with cold $\mathrm{MeOH}$, and then dried under vacuum at $55{ }^{\circ} \mathrm{C}$. A crystal of 36 with approximate dimensions of $0.25 \times 0.15 \times 0.04 \mathrm{~mm}$ was selected, mounted on a MicroMount and centered on a Bruker X8 Prospector diffractometer equipped with a $\mathrm{Cu} \mathrm{K} \alpha \mathrm{I} \mu \mathrm{s}$ microsource (at 40kV, $0.65 \mathrm{~mA}$ ) and a Photon II detector.

Three batches of 30 frames separated in reciprocal space were obtained to provide an orientation matrix and initial cell parameters. Final cell parameters were obtained and refined based on the full data set. A diffraction data set of reciprocal space was obtained to a resolution of $0.82 \AA$ using $1.0^{\circ}$ steps with $10 \mathrm{~s}$ exposure for each frame. Data were collected at $100 \mathrm{~K}$. 


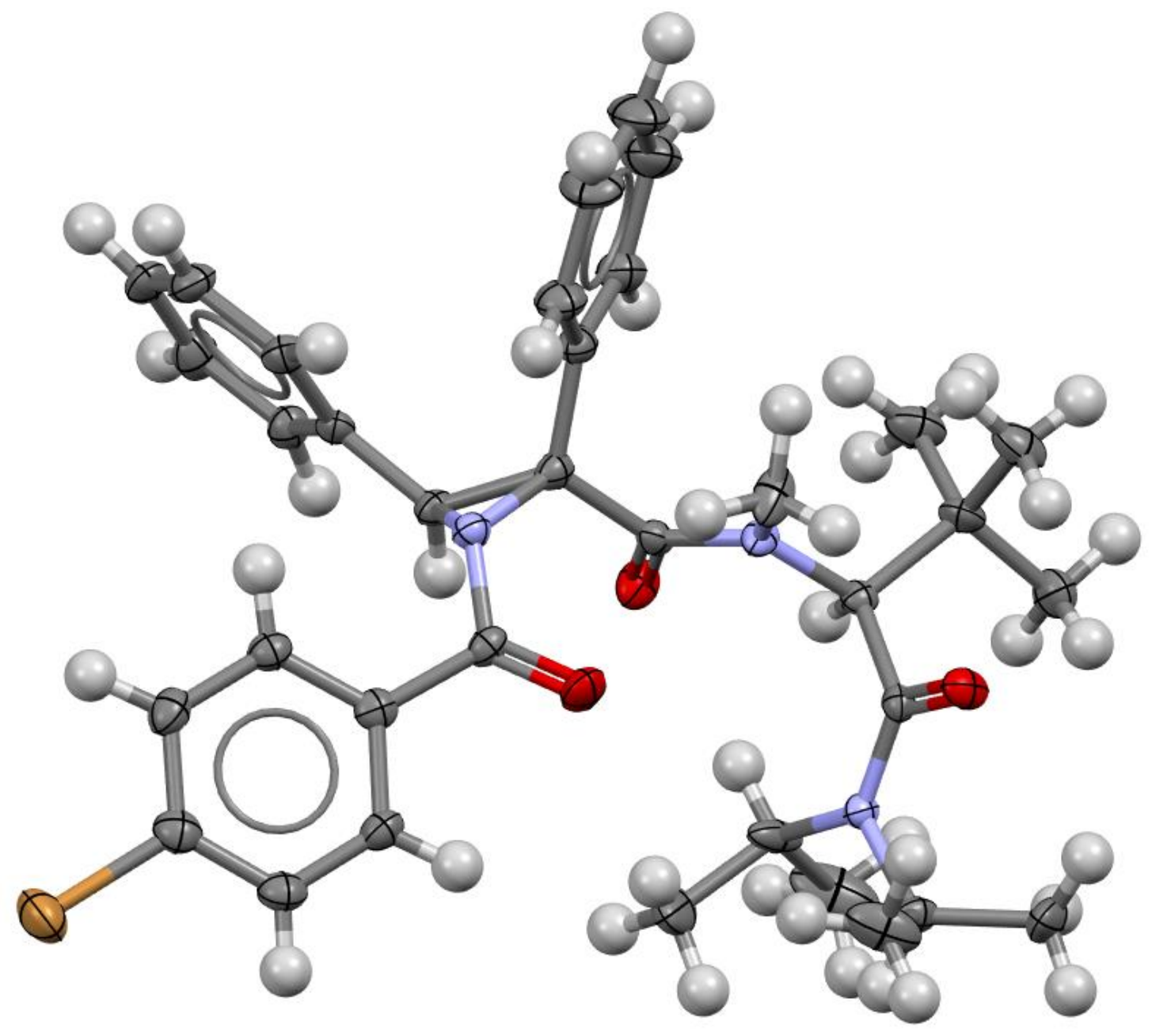

Figure 1. Thermal ellipsoid drawing of the molecule of (2R,3S)-1-(4-bromobenzoyl)- $N-((S)-1-$ (diisopropylamino)-3,3-dimethyl-1-oxobutan-2-yl)- $N$-methyl-2,3-diphenylaziridine-2-carboxamide (36). The ellipsoids are drawn at the 50\% probability level. Hydrogen atoms are represented by spheres of an arbitrary radius of $0.30 \AA$. 
Table 1 Crystal data and structure refinement for RDG-JTR1-01338 (36).

Identification code

Empirical formula

Formula weight

Temperature/K

Crystal system

Space group

$\mathrm{a} / \AA$

$\mathrm{b} / \AA$

$\mathrm{c} / \AA$

$\alpha /^{\circ}$

$\beta /{ }^{\circ}$

$\gamma /{ }^{\circ}$

Volume $/ \AA^{3}$

Z

$\rho_{\text {calc } g / \mathrm{cm}^{3}}$

$\mu / \mathrm{mm}^{-1}$

$\mathrm{F}(000)$

Crystal size $/ \mathrm{mm}^{3}$

Radiation

$2 \Theta$ range for data collection/ ${ }^{\circ}$

Index ranges

Reflections collected

Independent reflections

Data/restraints/parameters

Goodness-of-fit on $\mathrm{F}^{2}$

Final $\mathrm{R}$ indexes $[\mathrm{I}>=2 \sigma(\mathrm{I})]$

Final R indexes [all data]

Largest diff. peak/hole / e $\AA^{-3}$

Flack parameter
RDG-JTR1-01338

$\mathrm{C}_{35} \mathrm{H}_{42} \mathrm{BrN}_{3} \mathrm{O}_{3}$

632.62

100.15

orthorhombic

$\mathrm{P} 2{ }_{1} 2_{1} 2_{1}$

8.9666(3)

$15.1587(4)$

24.2176(8)

90

90

90

$3291.70(18)$

4

1.277

1.993

1328.0

$0.25 \times 0.15 \times 0.04$

$\mathrm{CuK} \alpha(\lambda=1.54178)$

7.3 to 141.64

$-10 \leq \mathrm{h} \leq 10,-18 \leq \mathrm{k} \leq 18,-29 \leq 1 \leq 29$

45905

$6241\left[\mathrm{R}_{\text {int }}=0.0541, \mathrm{R}_{\text {sigma }}=0.0331\right]$

$6241 / 0 / 547$

1.151

$\mathrm{R}_{1}=0.0388, \mathrm{wR}_{2}=0.0905$

$\mathrm{R}_{1}=0.0395, \mathrm{wR}_{2}=0.0909$

$0.37 /-0.34$

$0.020(8)$ 
(2): ${ }^{1} \mathrm{H}$ NMR $(400 \mathrm{MHz})$ in $\mathrm{CDCl}_{3}$
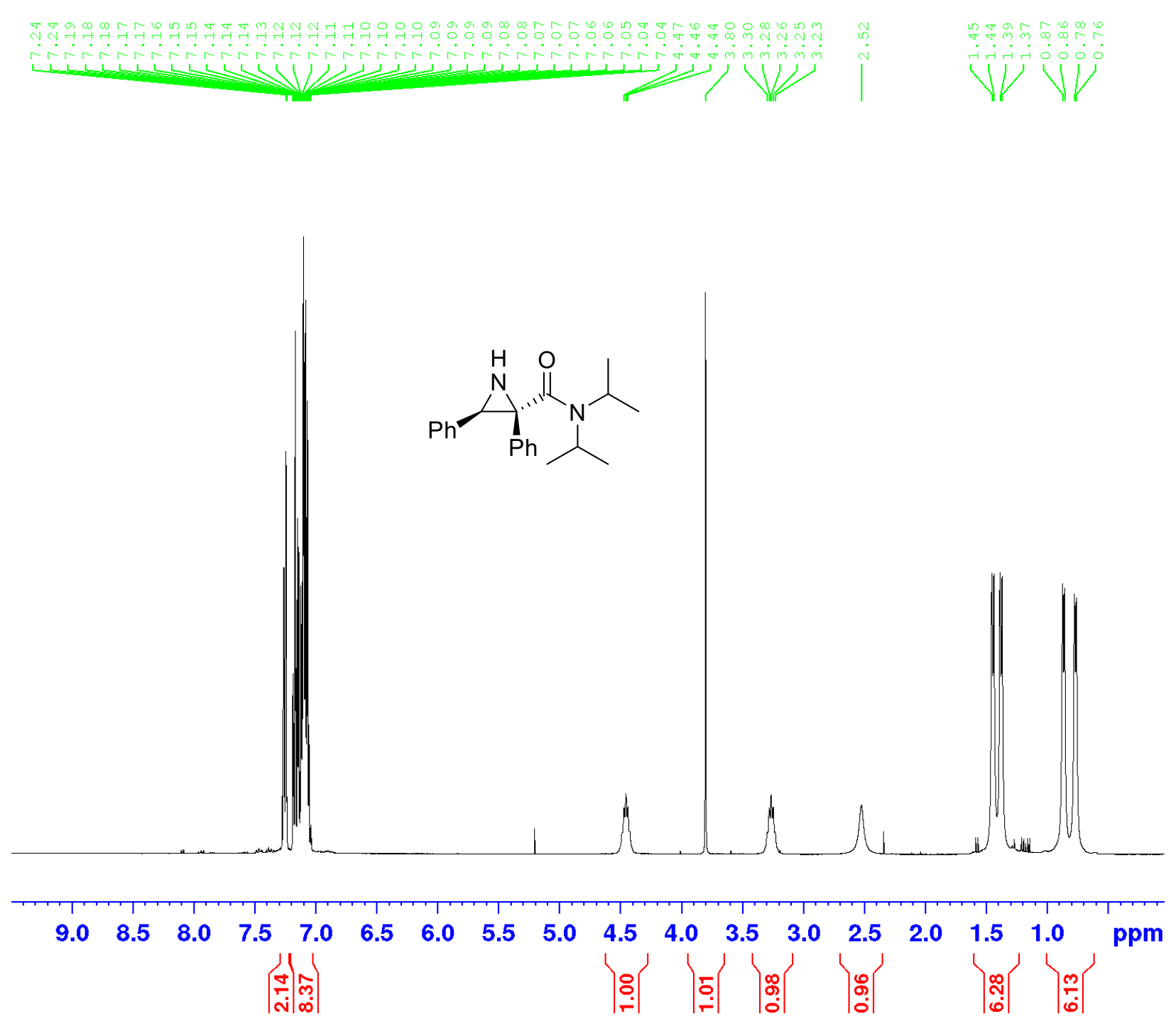
(2): ${ }^{13} \mathrm{C} \mathrm{NMR} \mathrm{(100} \mathrm{MHz)} \mathrm{in} \mathrm{CDCl}_{3}$

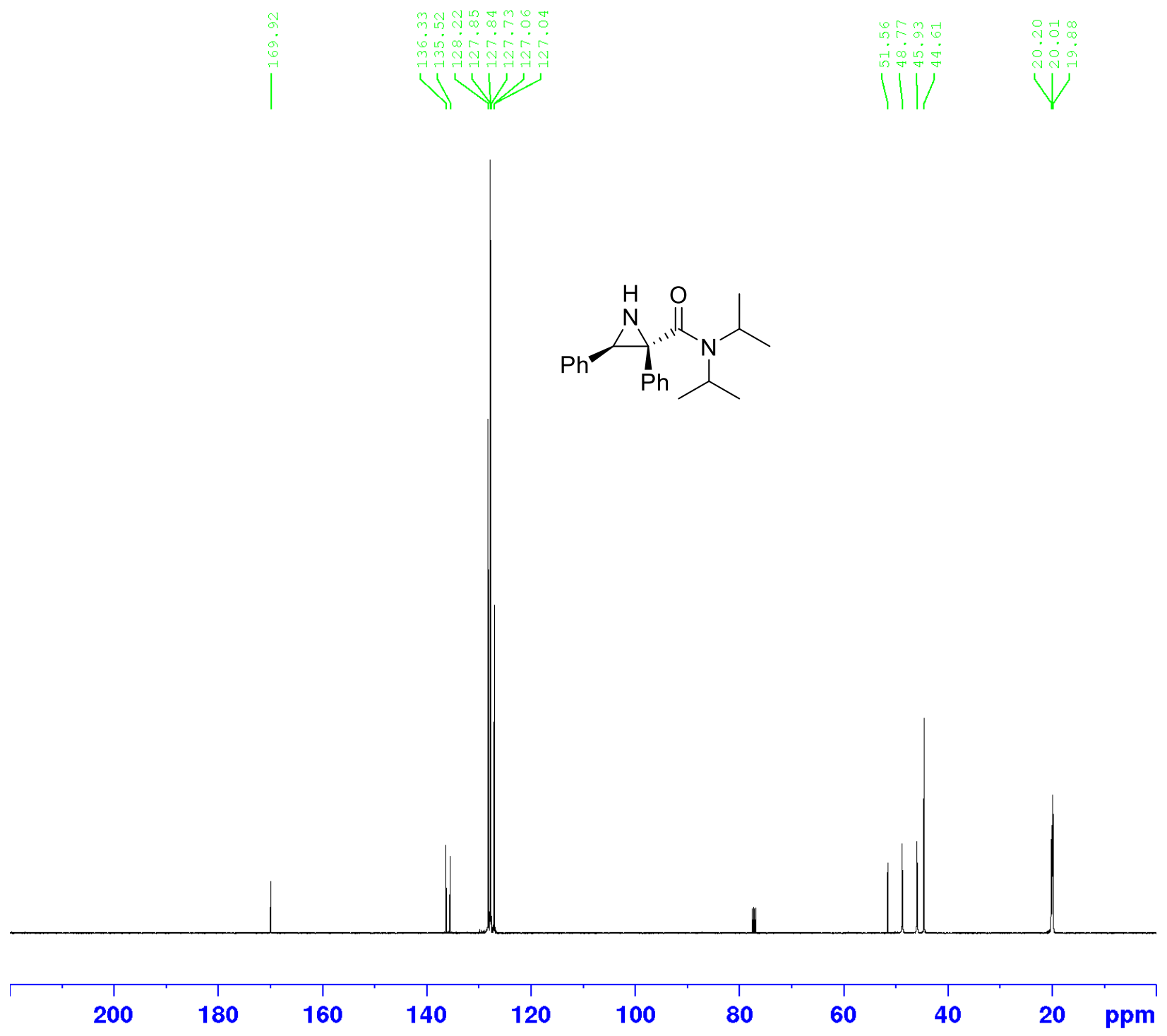


(3): ${ }^{1} \mathrm{H}$ NMR (400 MHz) in $\mathrm{CDCl}_{3}$

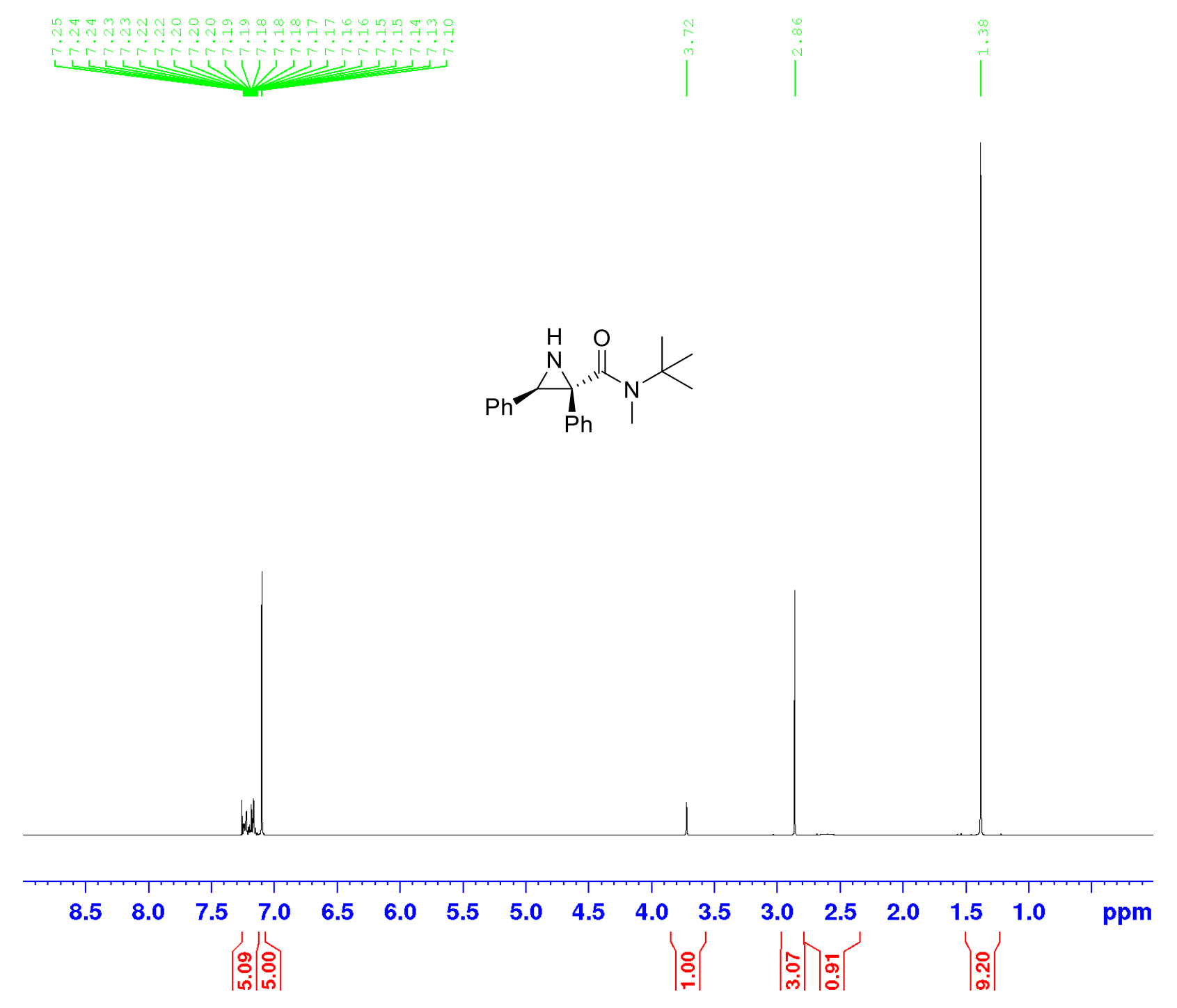


(3): ${ }^{13} \mathrm{C} \mathrm{NMR}(100 \mathrm{MHz})$ in $\mathrm{CDCl}_{3}$

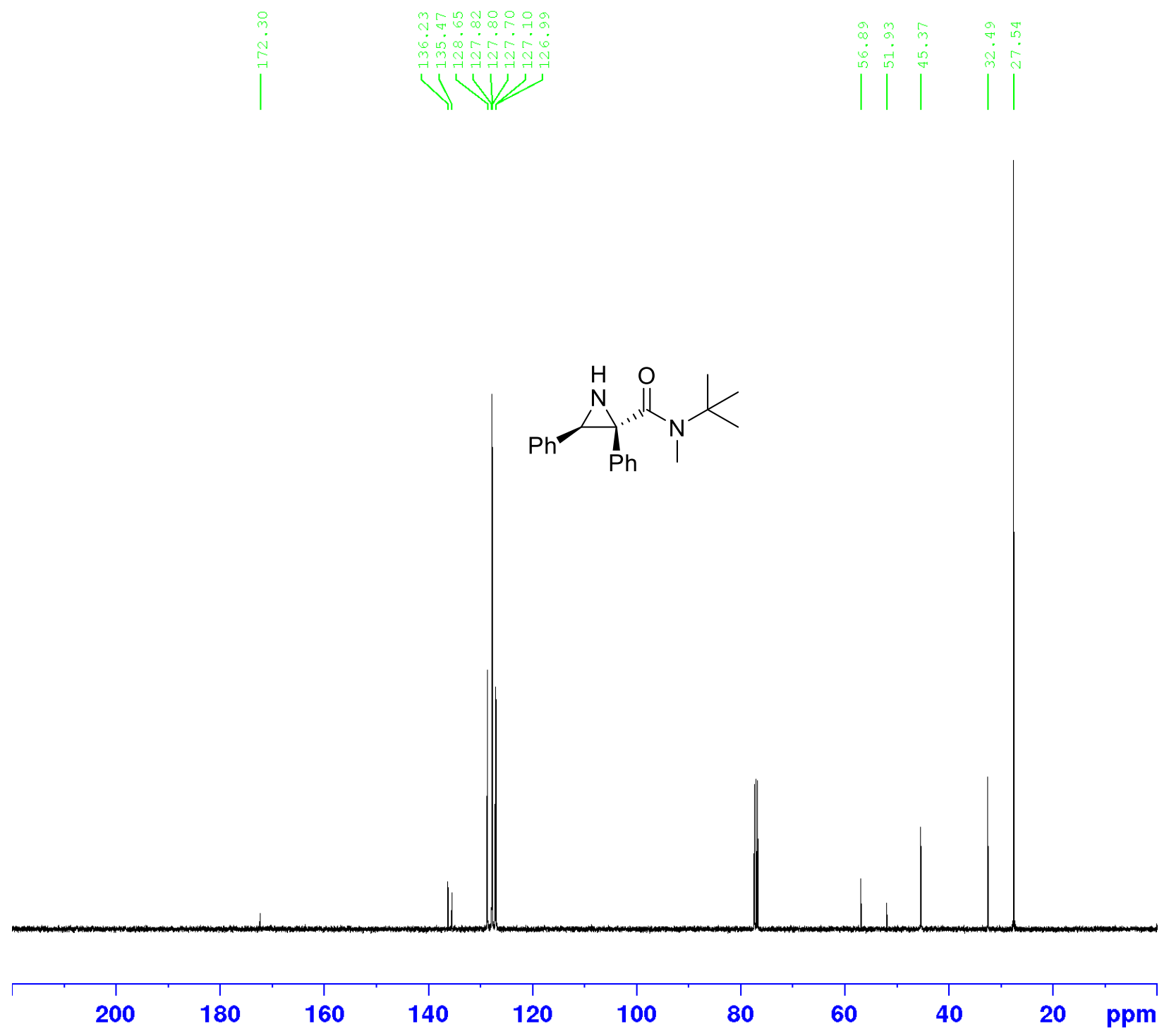


(4): ${ }^{1} \mathrm{H}$ NMR (400 MHz) in $\mathrm{CDCl}_{3}$

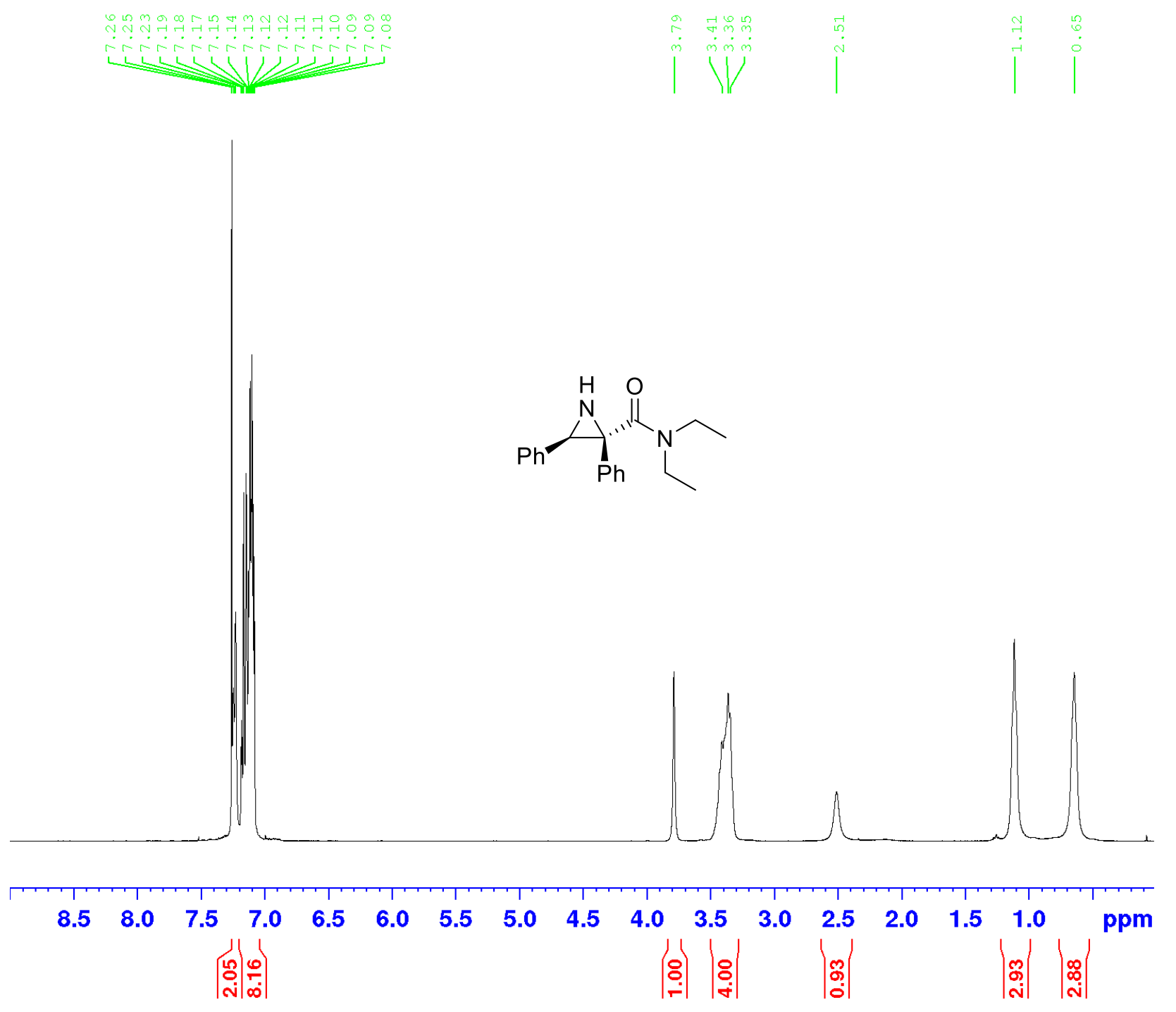


(4): ${ }^{13} \mathrm{C} \mathrm{NMR} \mathrm{(100} \mathrm{MHz)} \mathrm{in} \mathrm{CDCl}_{3}$

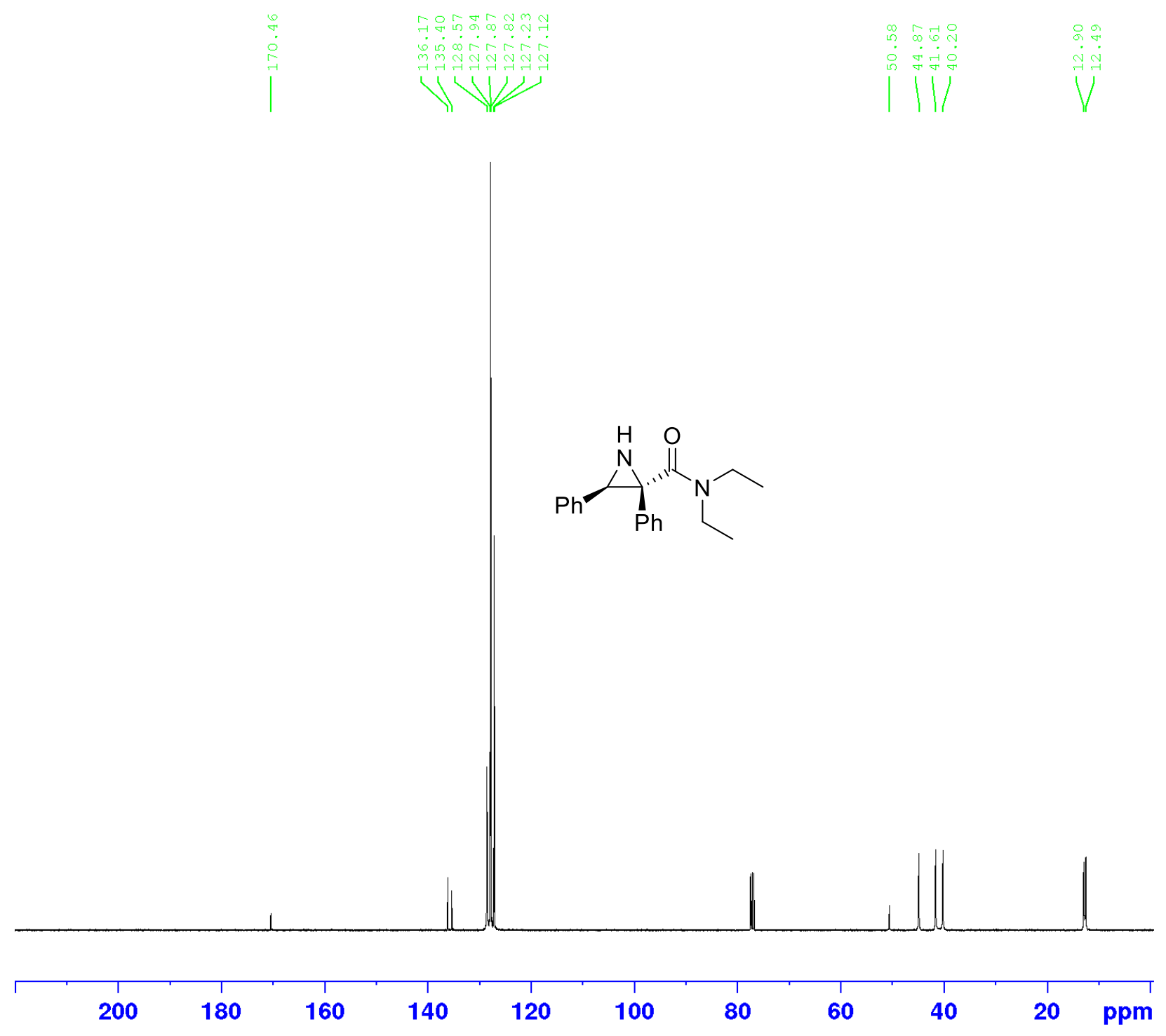


(5): ${ }^{1} \mathrm{H}$ NMR (400 MHz) in $\mathrm{CDCl}_{3}$

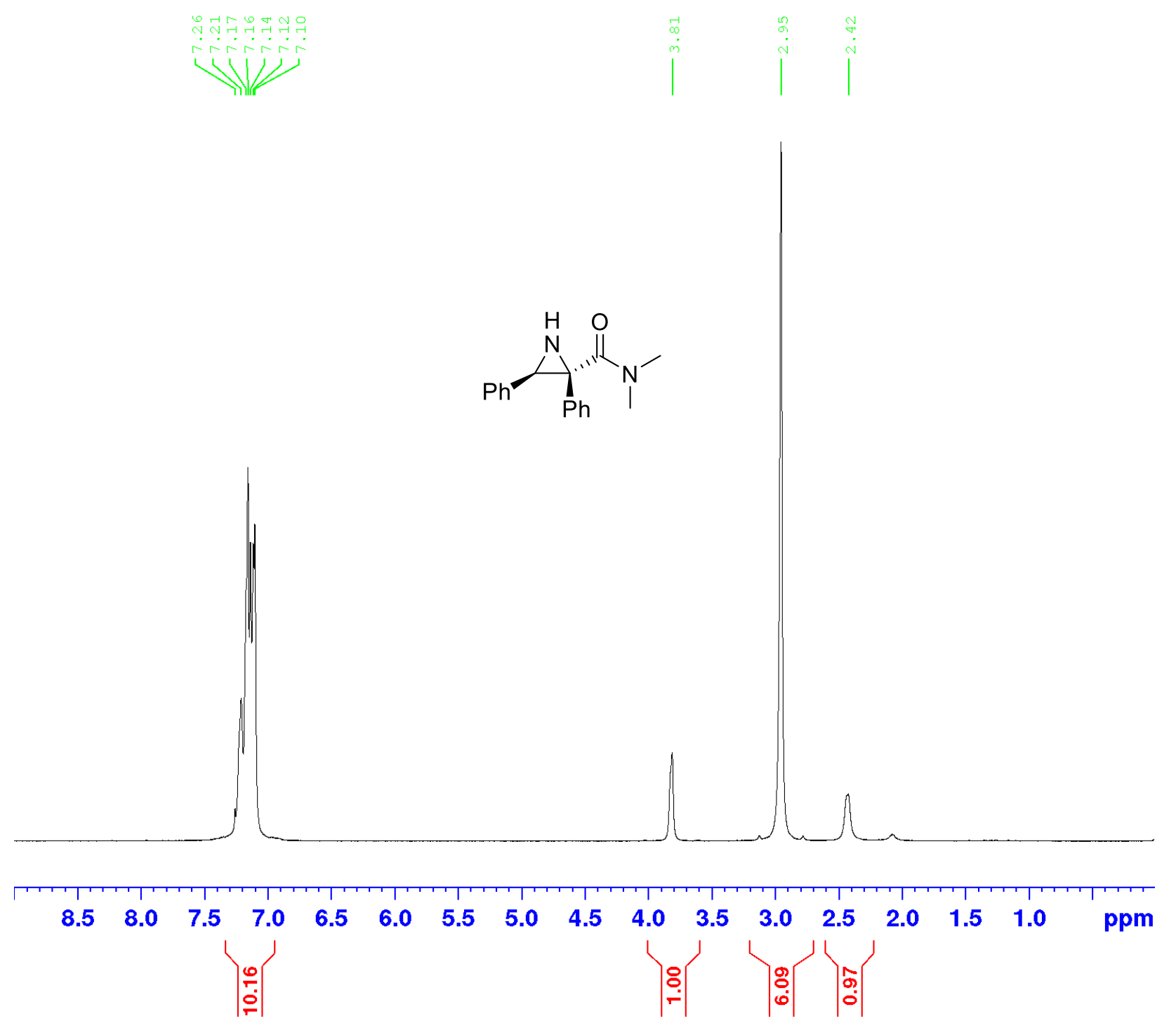


(5): ${ }^{13} \mathrm{C} \mathrm{NMR} \mathrm{(100} \mathrm{MHz)} \mathrm{in} \mathrm{CDCl}_{3}$

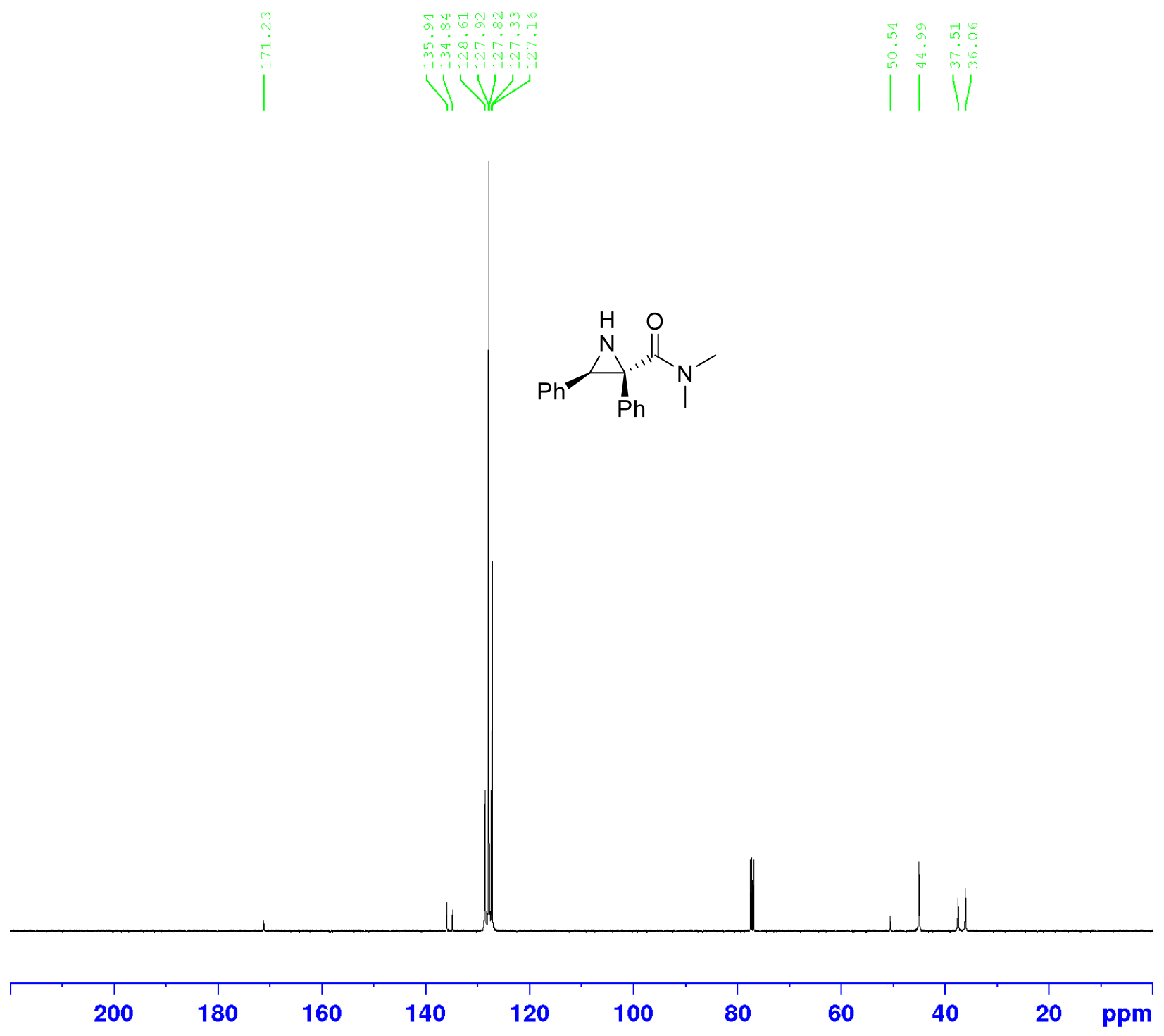


(6): ${ }^{1} \mathrm{H}$ NMR (400 MHz) in $\mathrm{CDCl}_{3}$

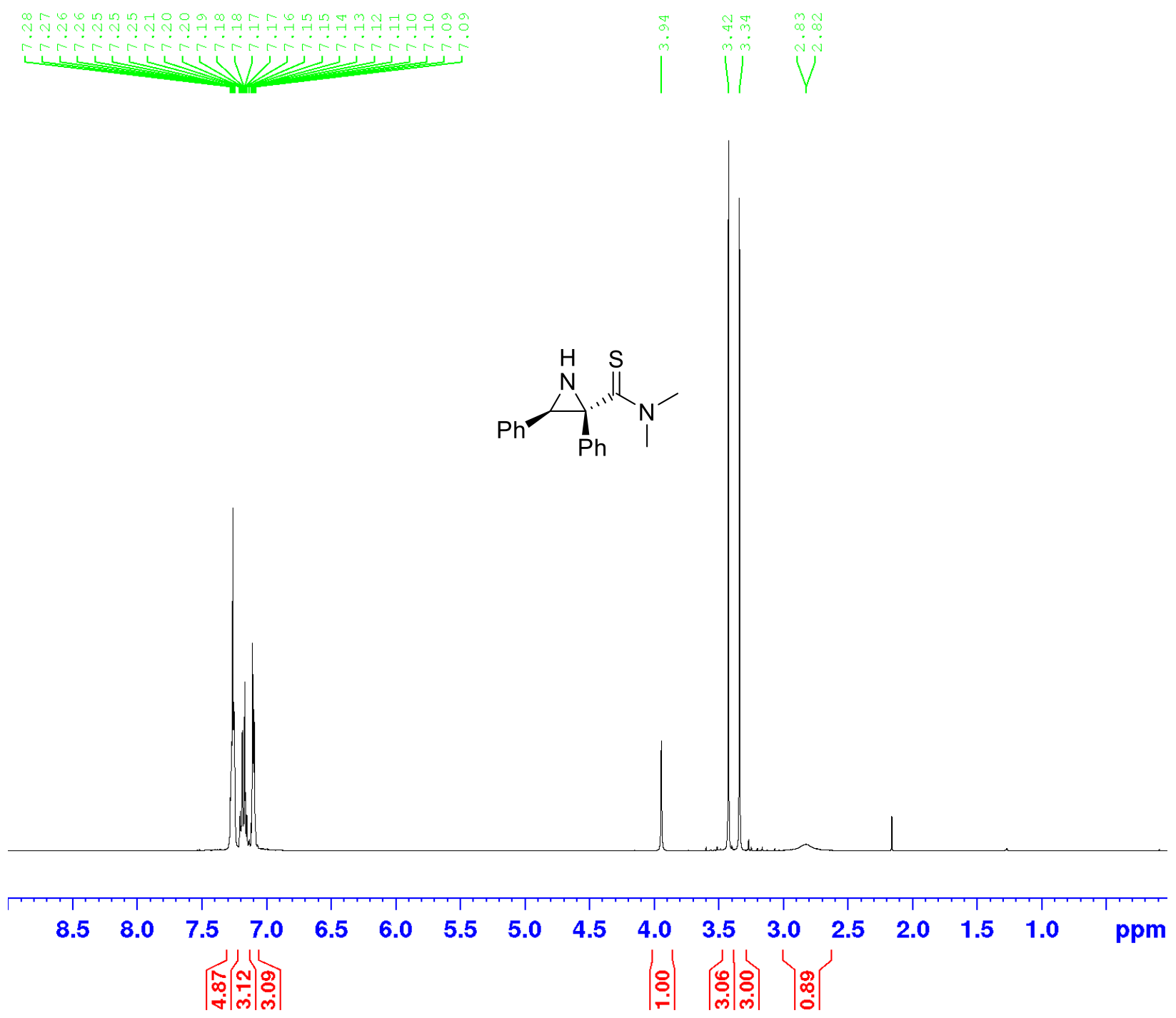


(6): ${ }^{13} \mathrm{C} \mathrm{NMR}(100 \mathrm{MHz})$ in $\mathrm{CDCl}_{3}$

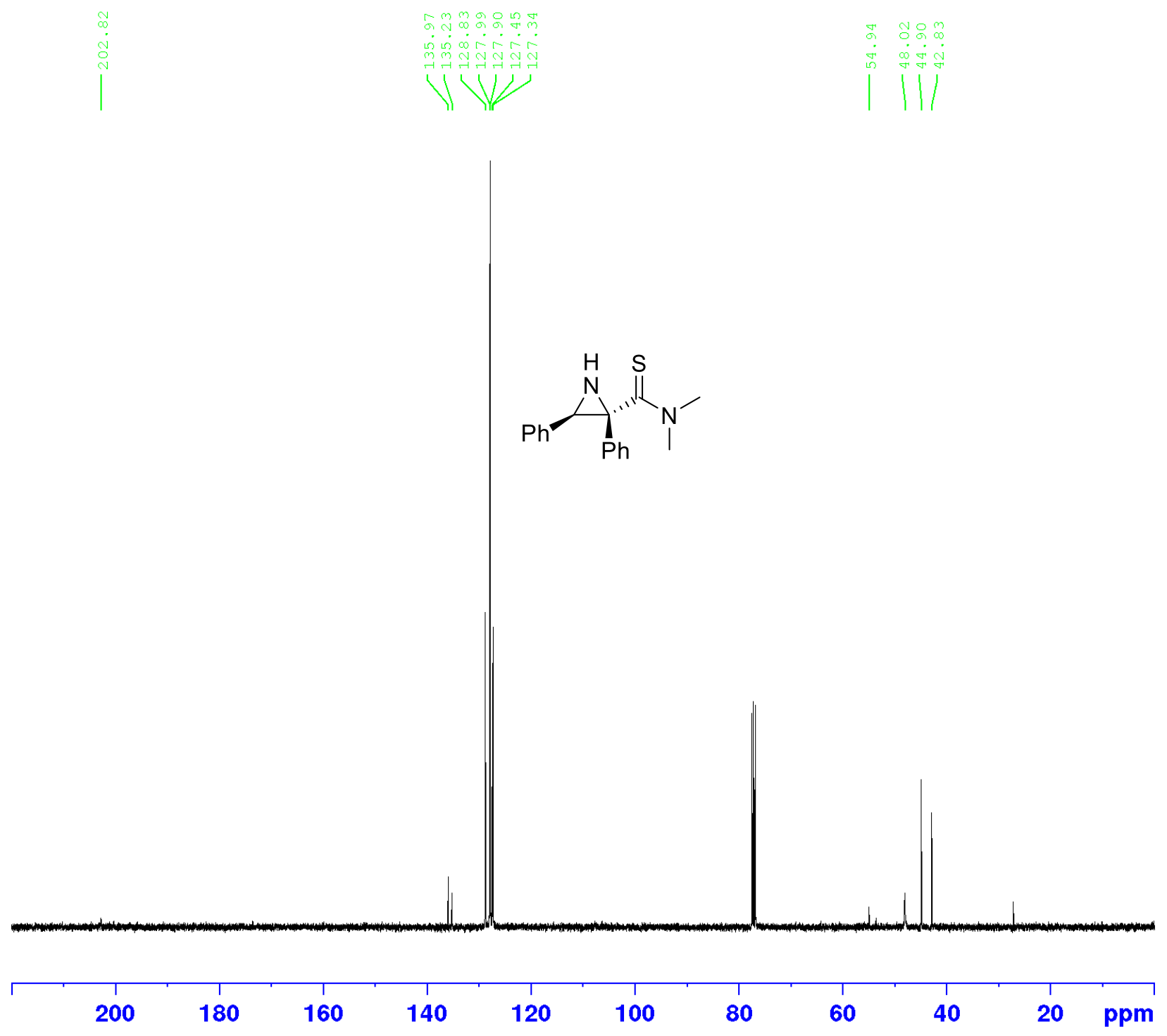


(7): ${ }^{1} \mathrm{H}$ NMR (400 MHz) in $\mathrm{CDCl}_{3}$

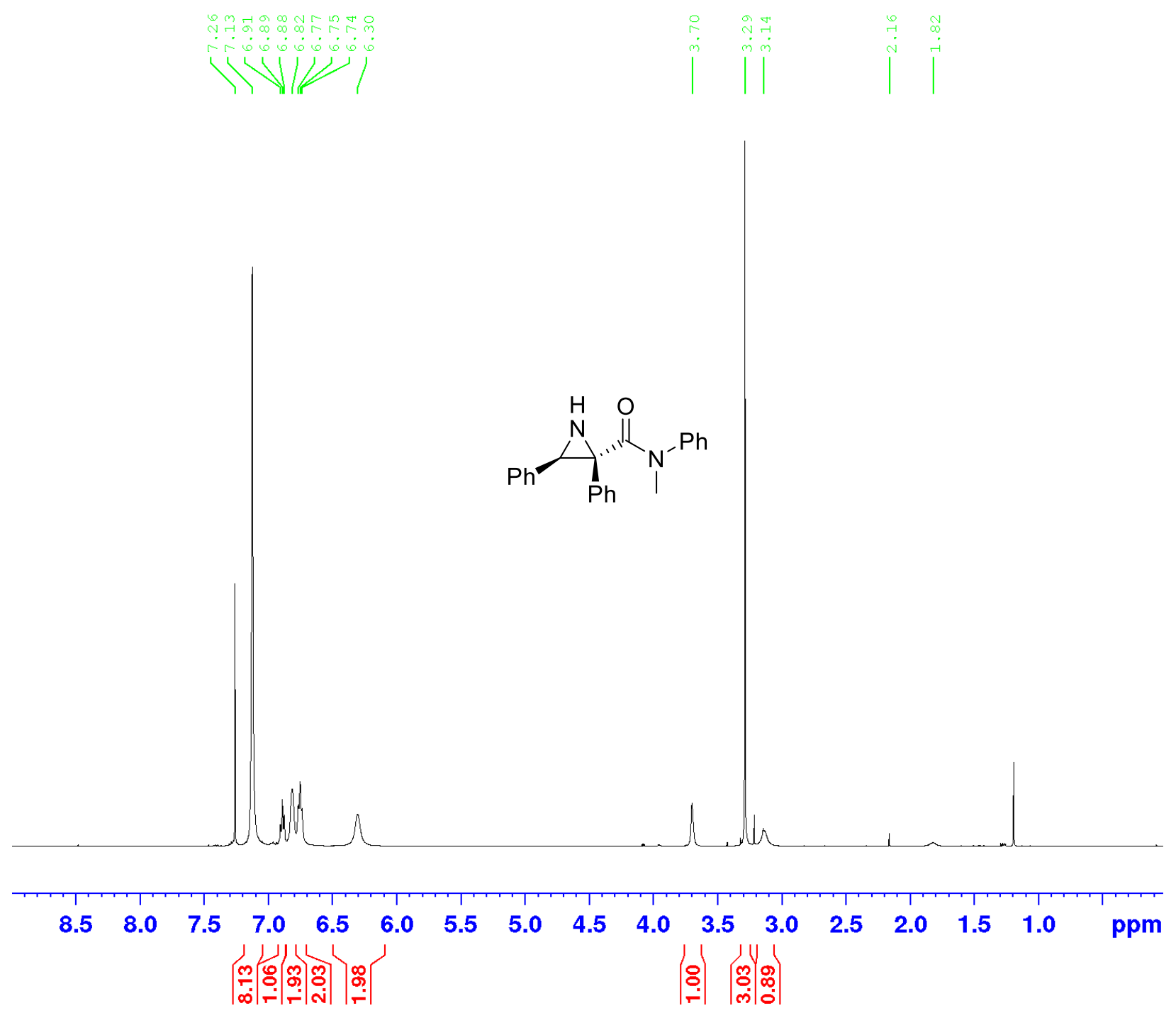


(7): ${ }^{13} \mathrm{C} \mathrm{NMR} \mathrm{(100} \mathrm{MHz)} \mathrm{in} \mathrm{CDCl}_{3}$

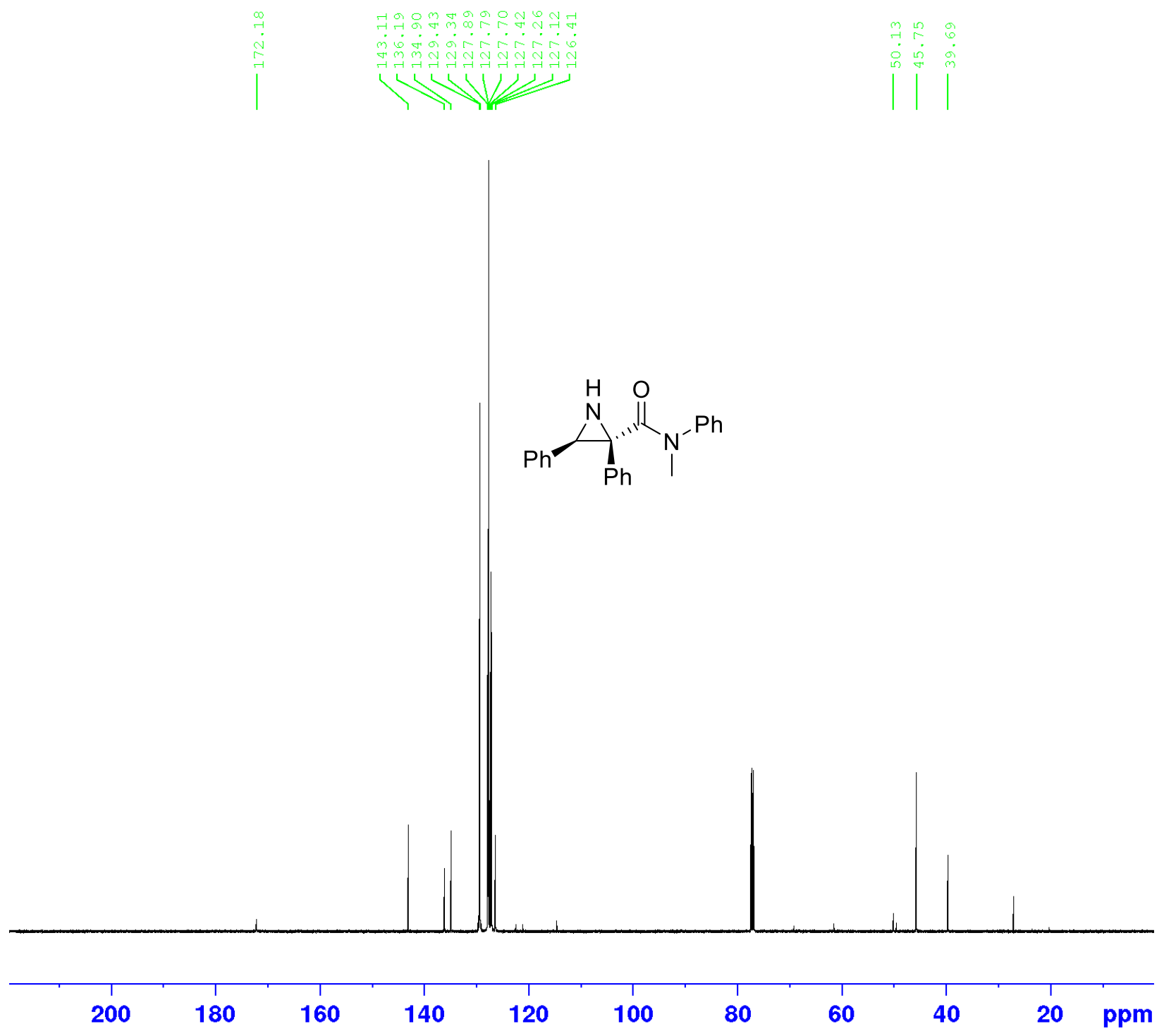


(8): ${ }^{1} \mathrm{H}$ NMR (400 MHz) in $\mathrm{CDCl}_{3}$

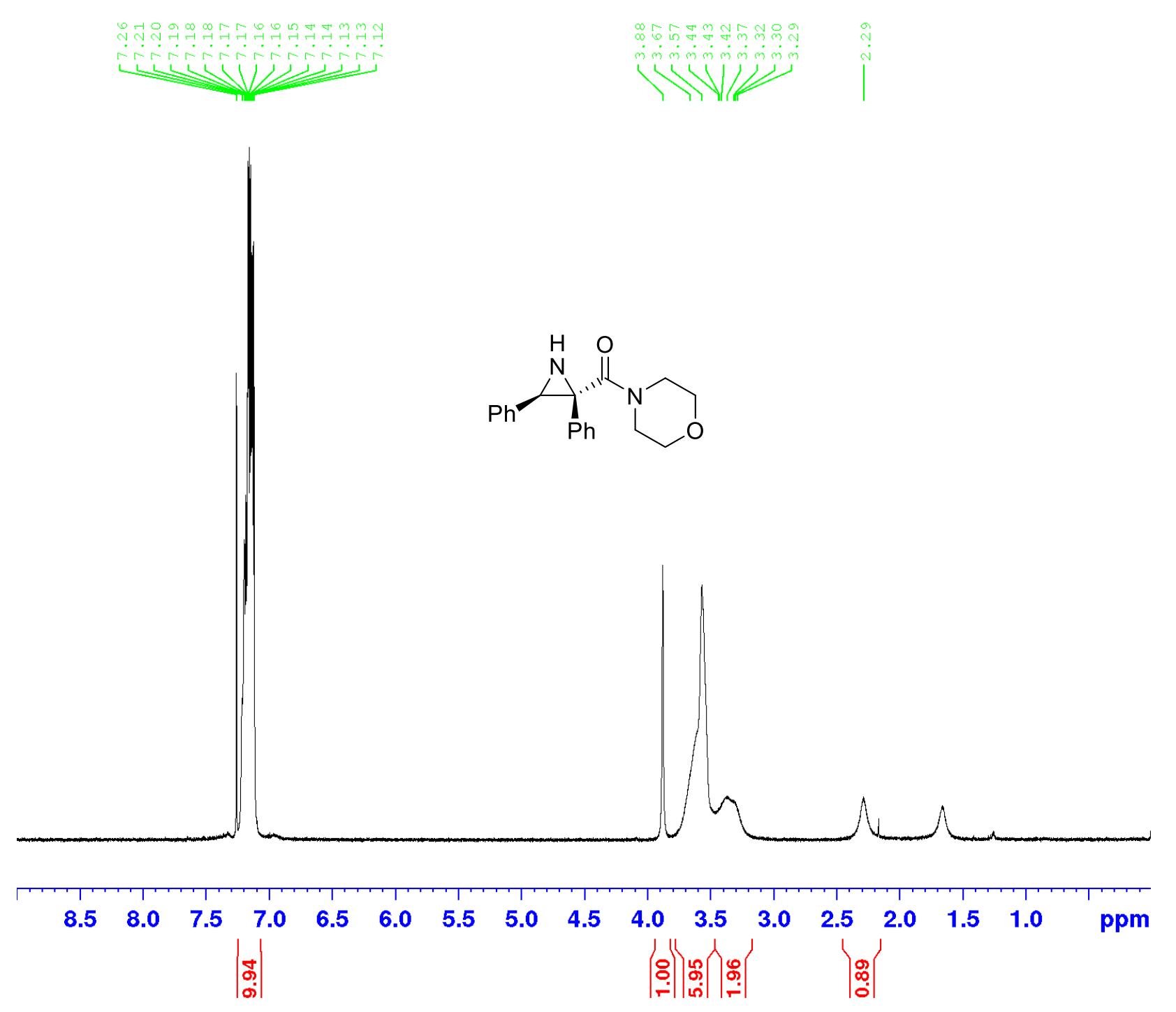


(8): ${ }^{13} \mathrm{C} \mathrm{NMR}(100 \mathrm{MHz})$ in $\mathrm{CDCl}_{3}$

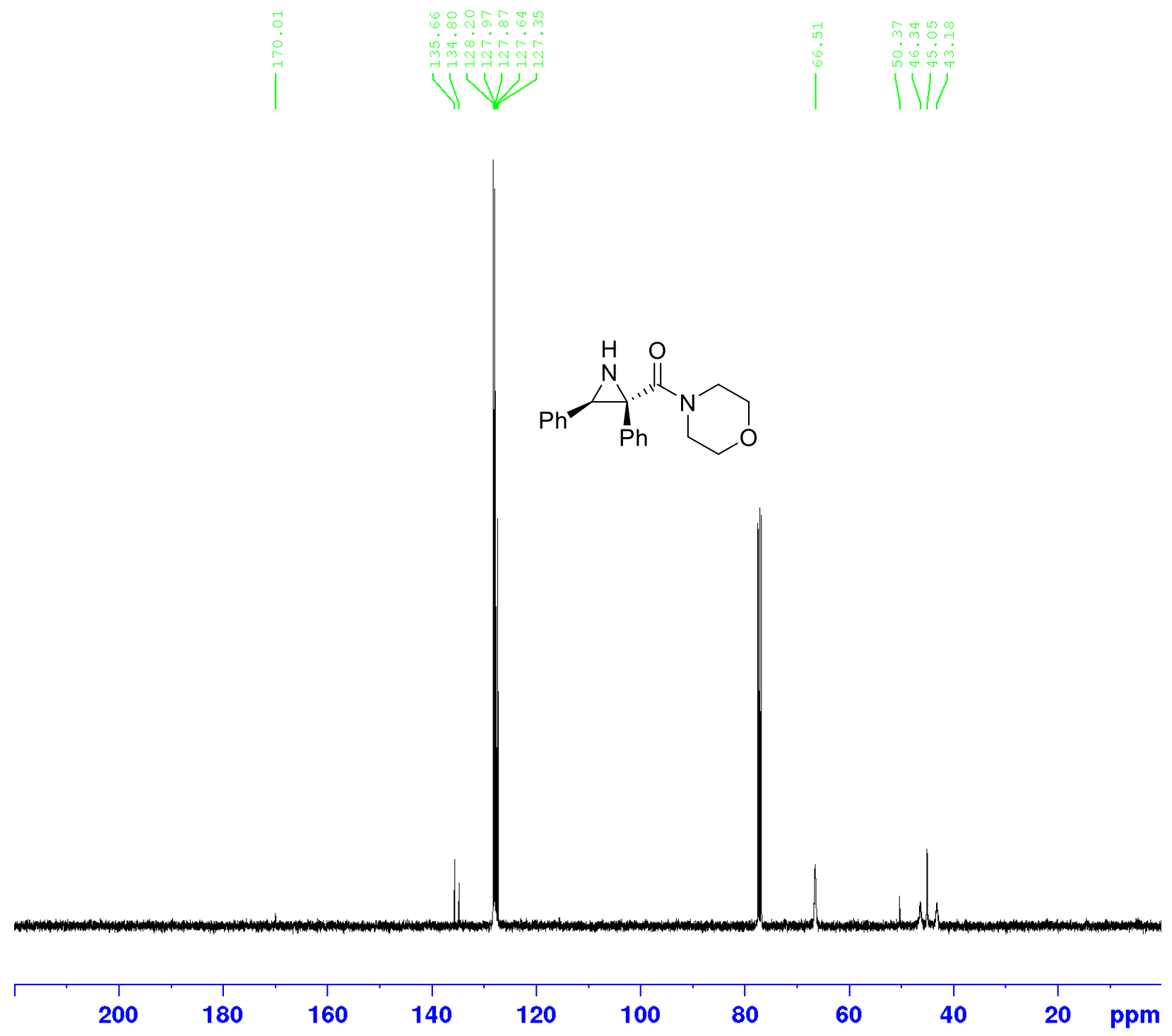


(9): ${ }^{1} \mathrm{H}$ NMR (400 MHz) in $\mathrm{CDCl}_{3}$

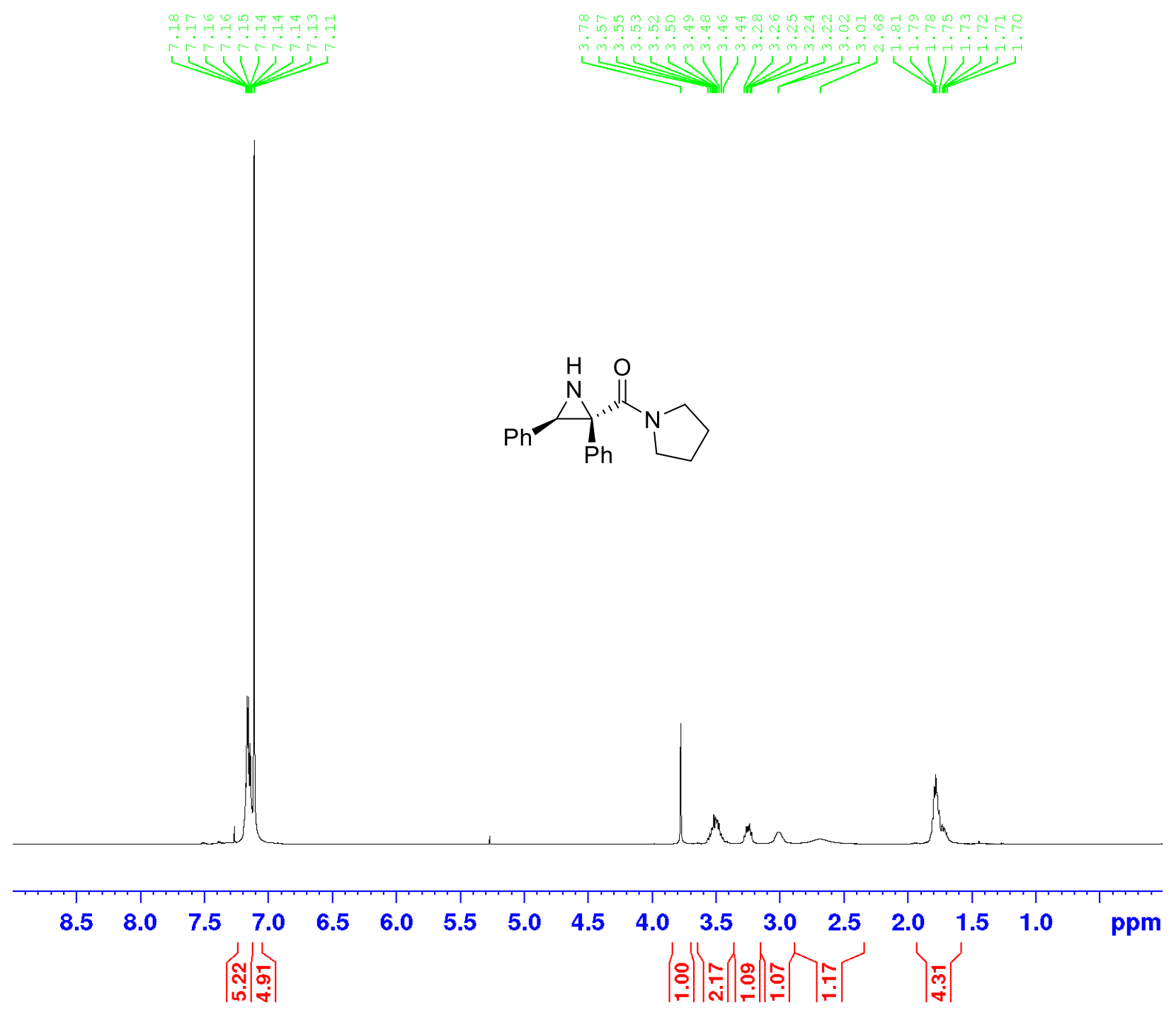


(9): ${ }^{13} \mathrm{C} \mathrm{NMR}(100 \mathrm{MHz})$ in $\mathrm{CDCl}_{3}$

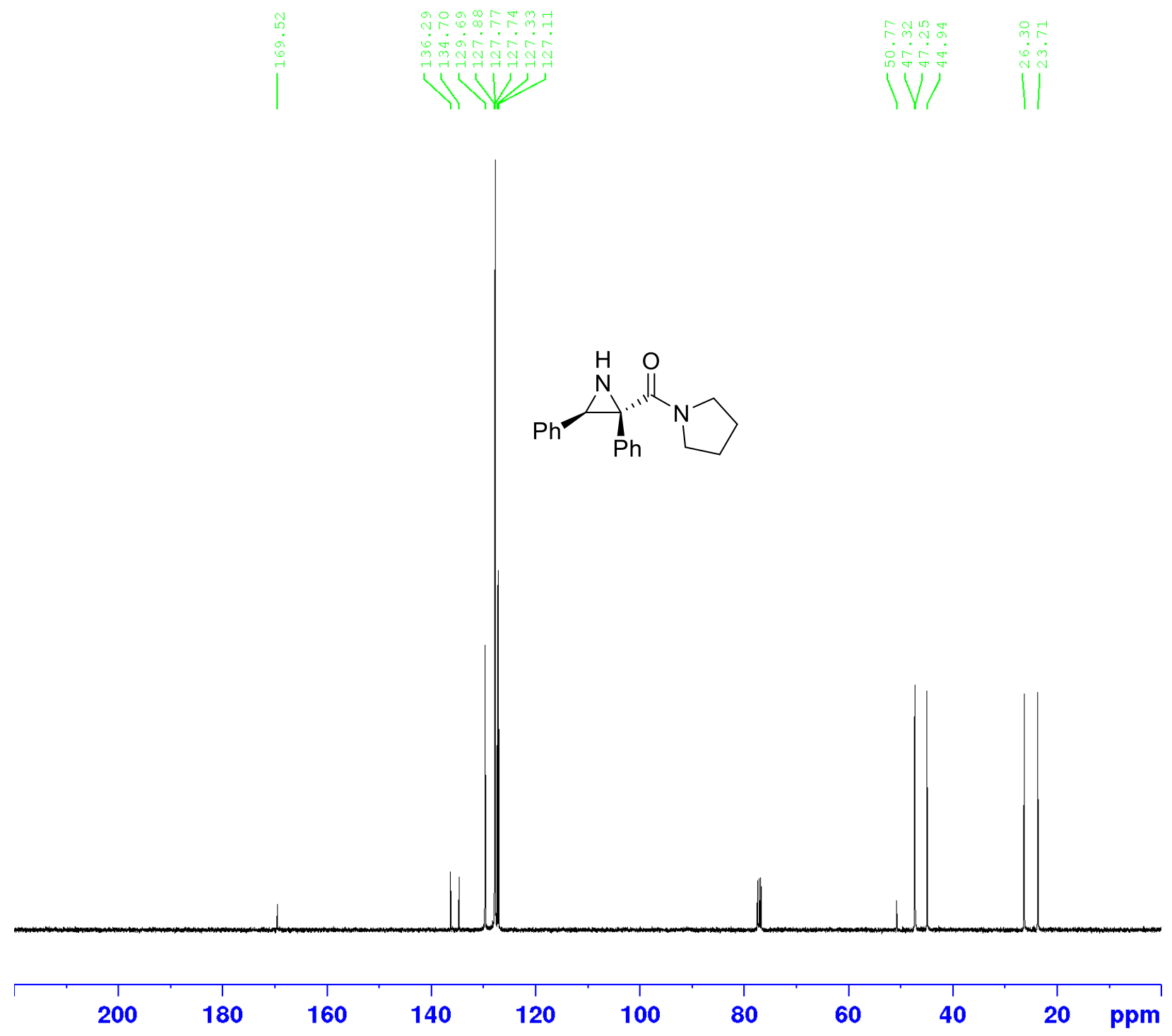


$N$-(2-((tert-butyldimethylsilyl)oxy)ethyl)-2-methylpropan-2-amine: ${ }^{1} \mathrm{H} \mathrm{NMR}(400 \mathrm{MHz})$ in $\mathrm{CDCl}_{3}$

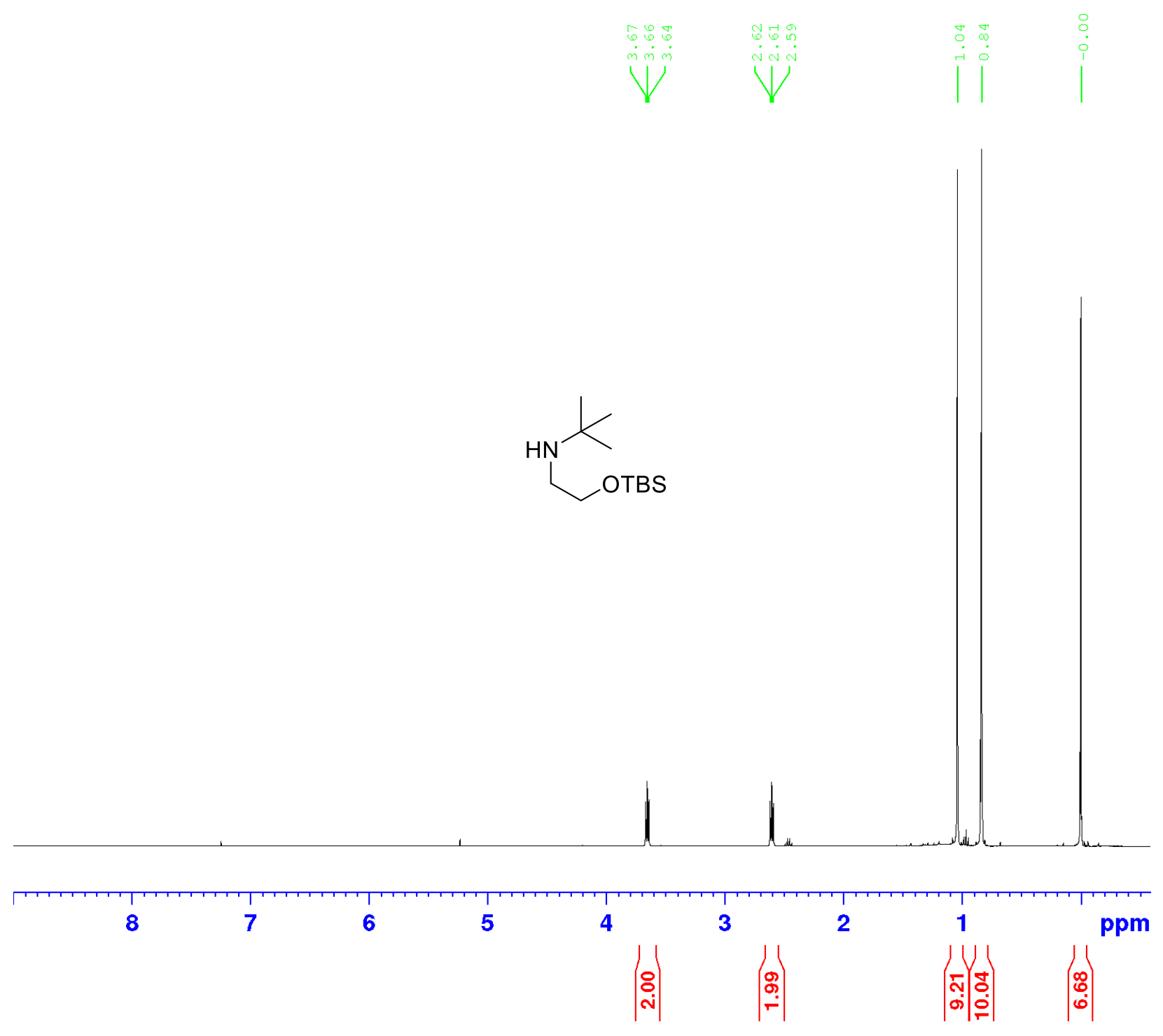


$N$-tert-butyl- $N$-(2-((tert-butyldimethylsilyl)oxy)ethyl)formamide: ${ }^{1} \mathrm{H} \mathrm{NMR}(400 \mathrm{MHz})$ in $\mathrm{CDCl}_{3}$

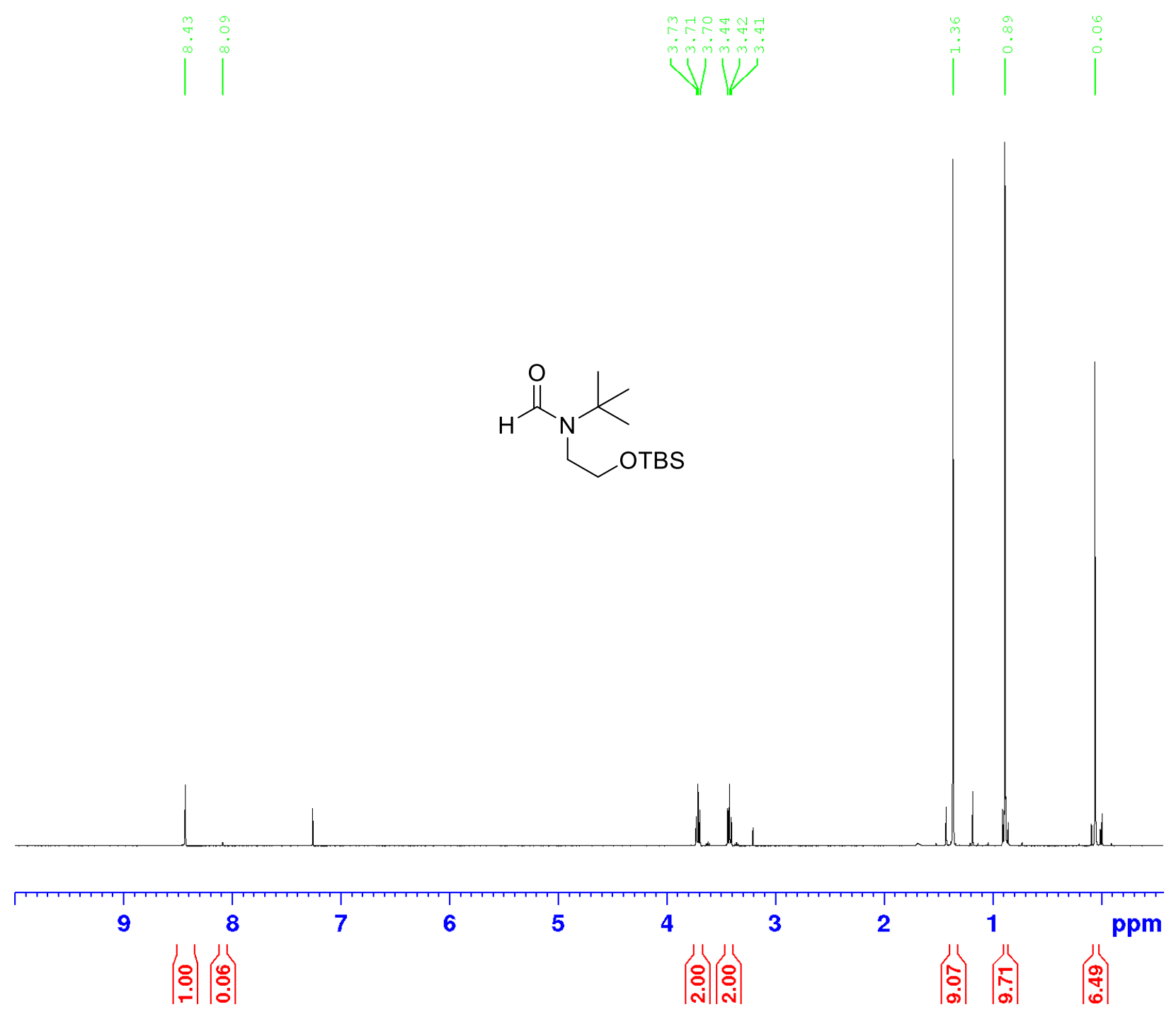


$N$-tert-butyl- $N$-(2-((tert-butyldimethylsilyl)oxy)ethyl)formamide: ${ }^{13} \mathrm{C} \mathrm{NMR} \mathrm{(100} \mathrm{MHz)} \mathrm{in} \mathrm{CDCl}_{3}$

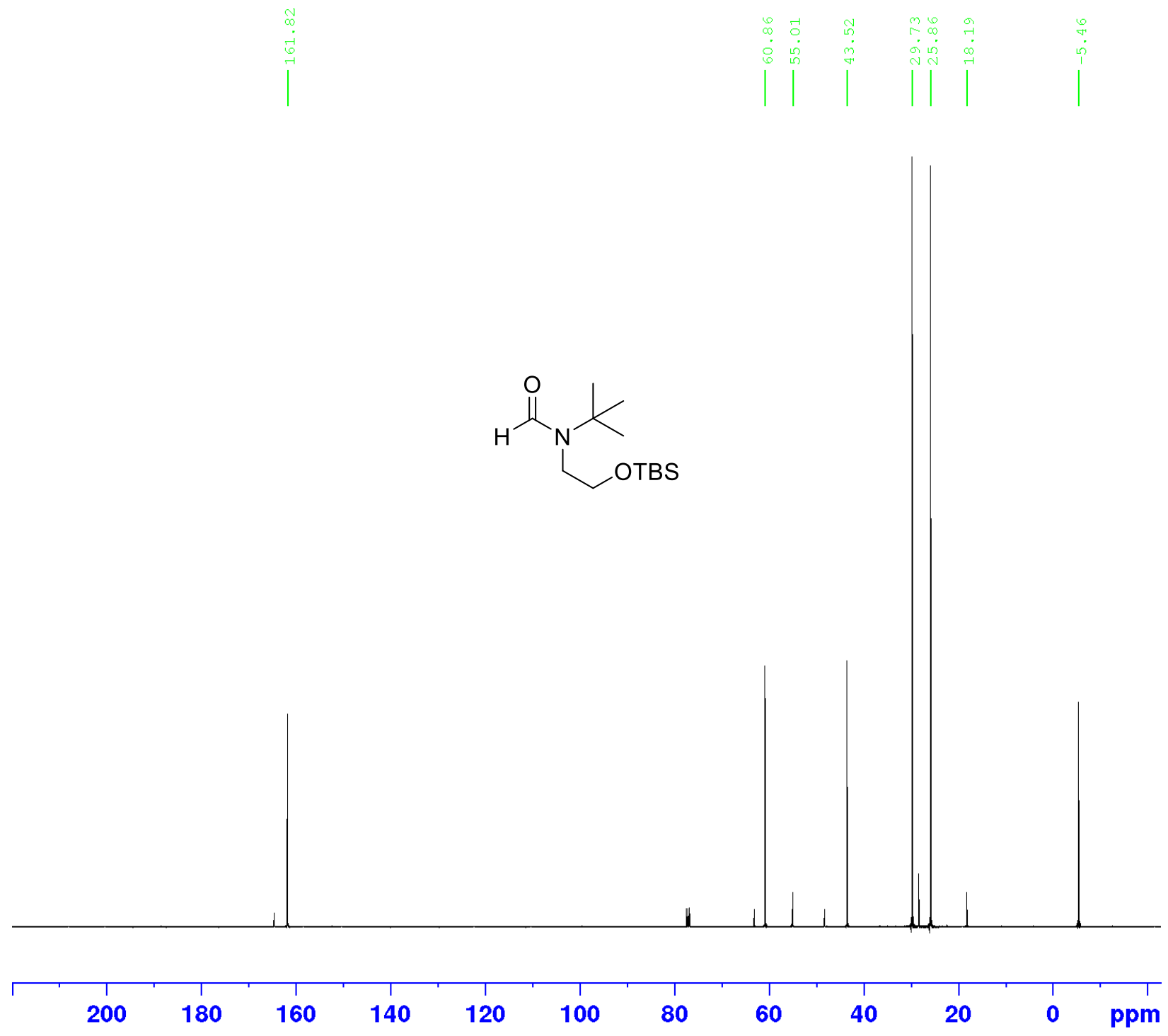


(10): ${ }^{1} \mathrm{H}$ NMR (400 MHz) in $\mathrm{CDCl}_{3}$

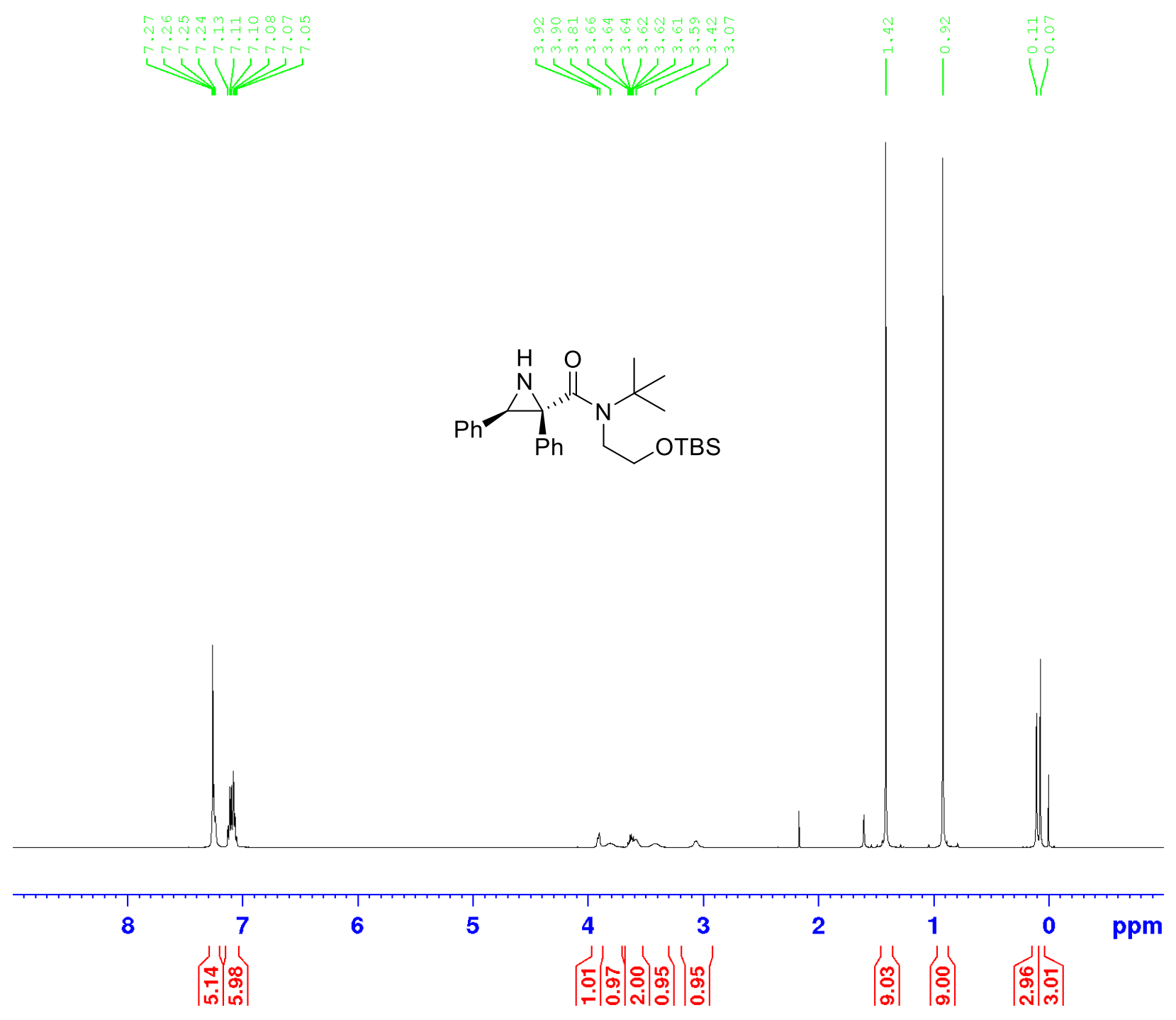


(10): ${ }^{13} \mathrm{C}$ NMR (100 MHz) in $\mathrm{CDCl}_{3}$

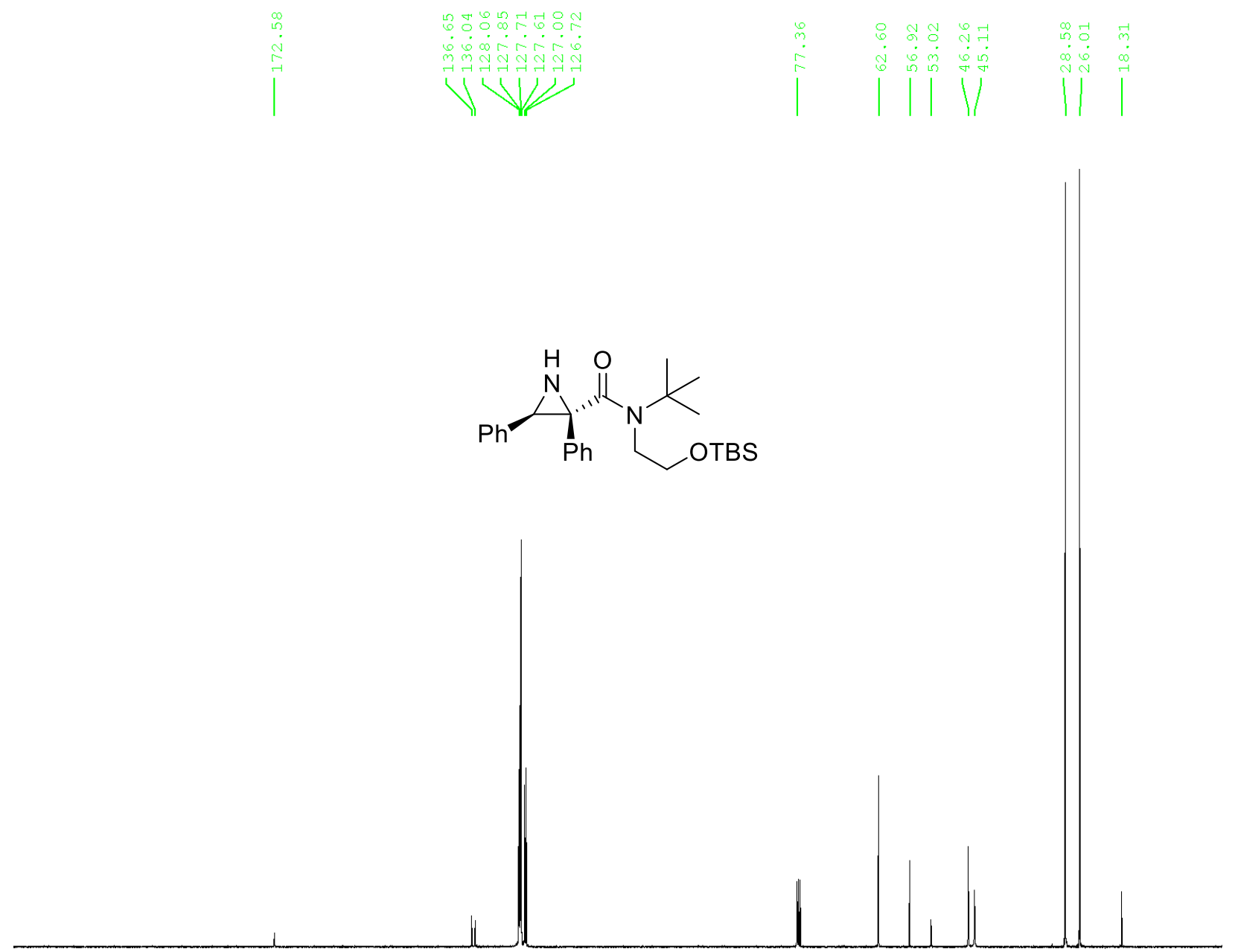

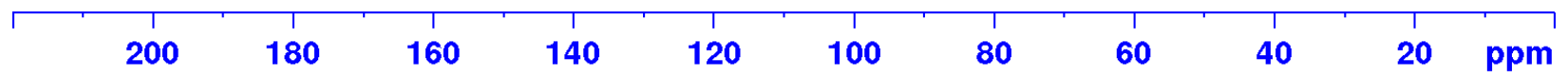


(2,2-dimethyloxazolidine-3-carbaldehyde): ${ }^{1} \mathrm{H} \mathrm{NMR}(400 \mathrm{MHz})$ in $\mathrm{CDCl}_{3}$

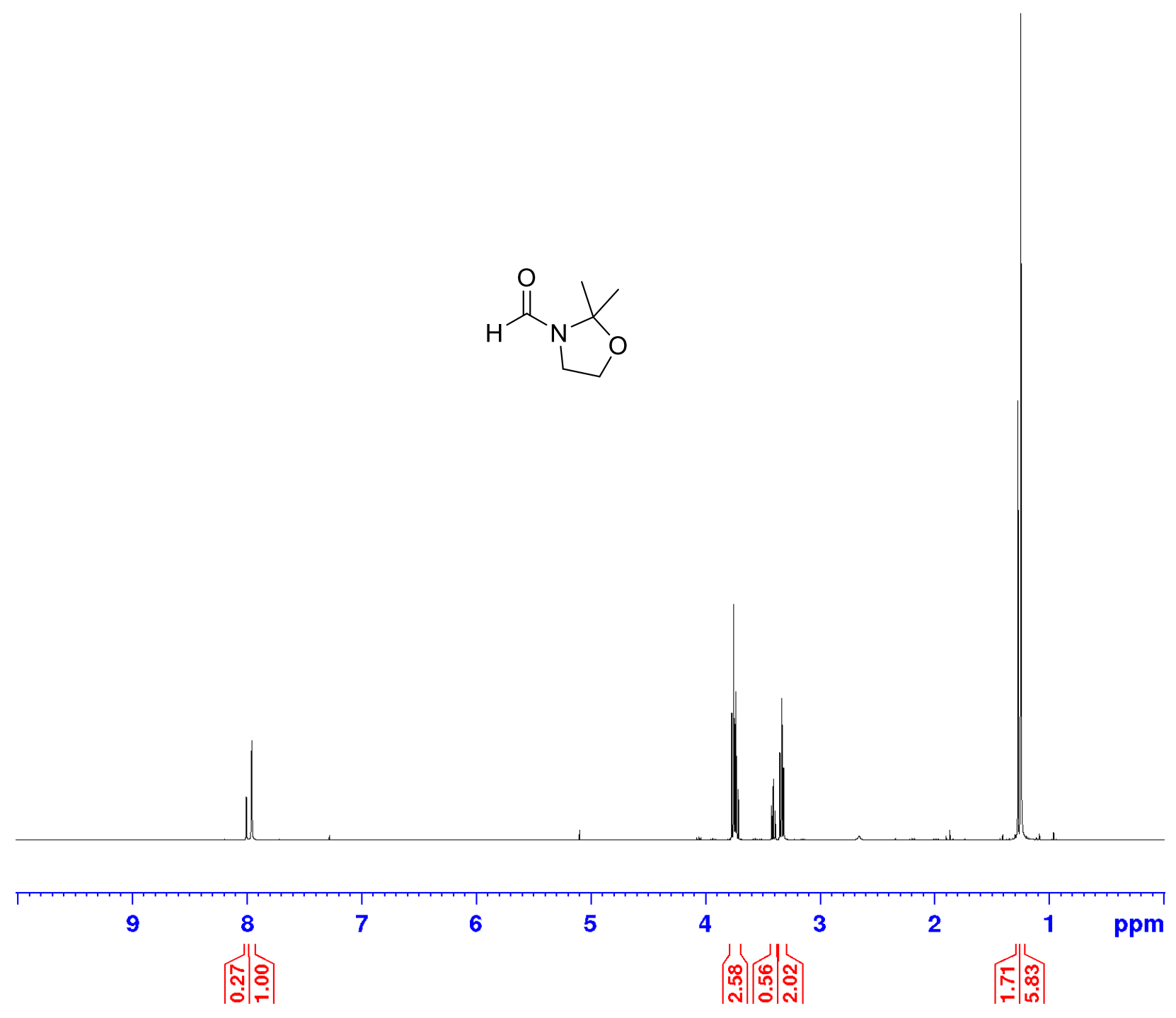


(2,2-dimethyloxazolidine-3-carbaldehyde): ${ }^{13} \mathrm{C} \mathrm{NMR} \mathrm{(100} \mathrm{MHz)} \mathrm{in} \mathrm{CDCl}_{3}$

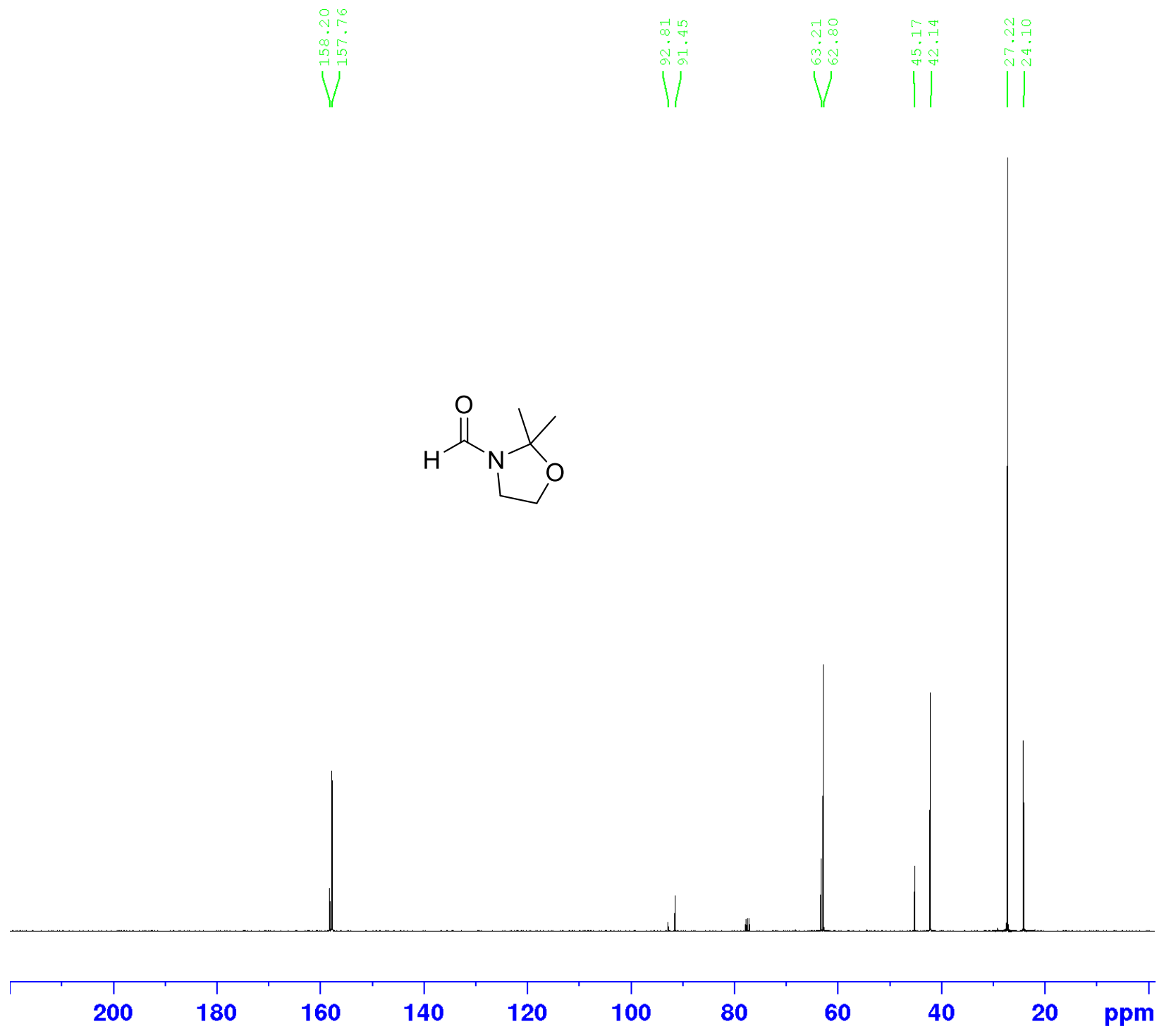


(11): ${ }^{1} \mathrm{H}$ NMR (500 MHz) in $\mathrm{CDCl}_{3}$

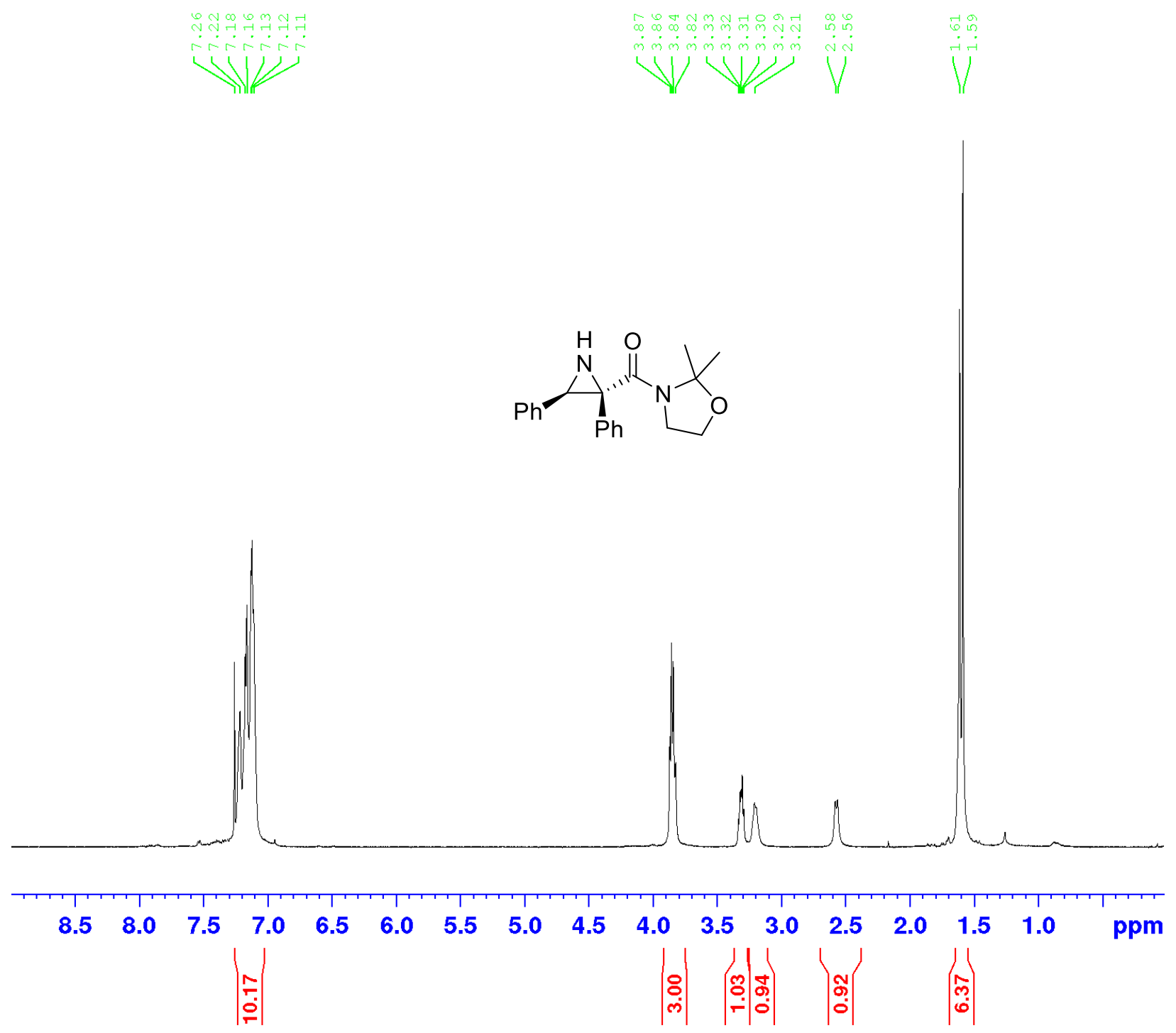


(11): ${ }^{13} \mathrm{C}$ NMR (100 MHz) in $\mathrm{CDCl}_{3}$

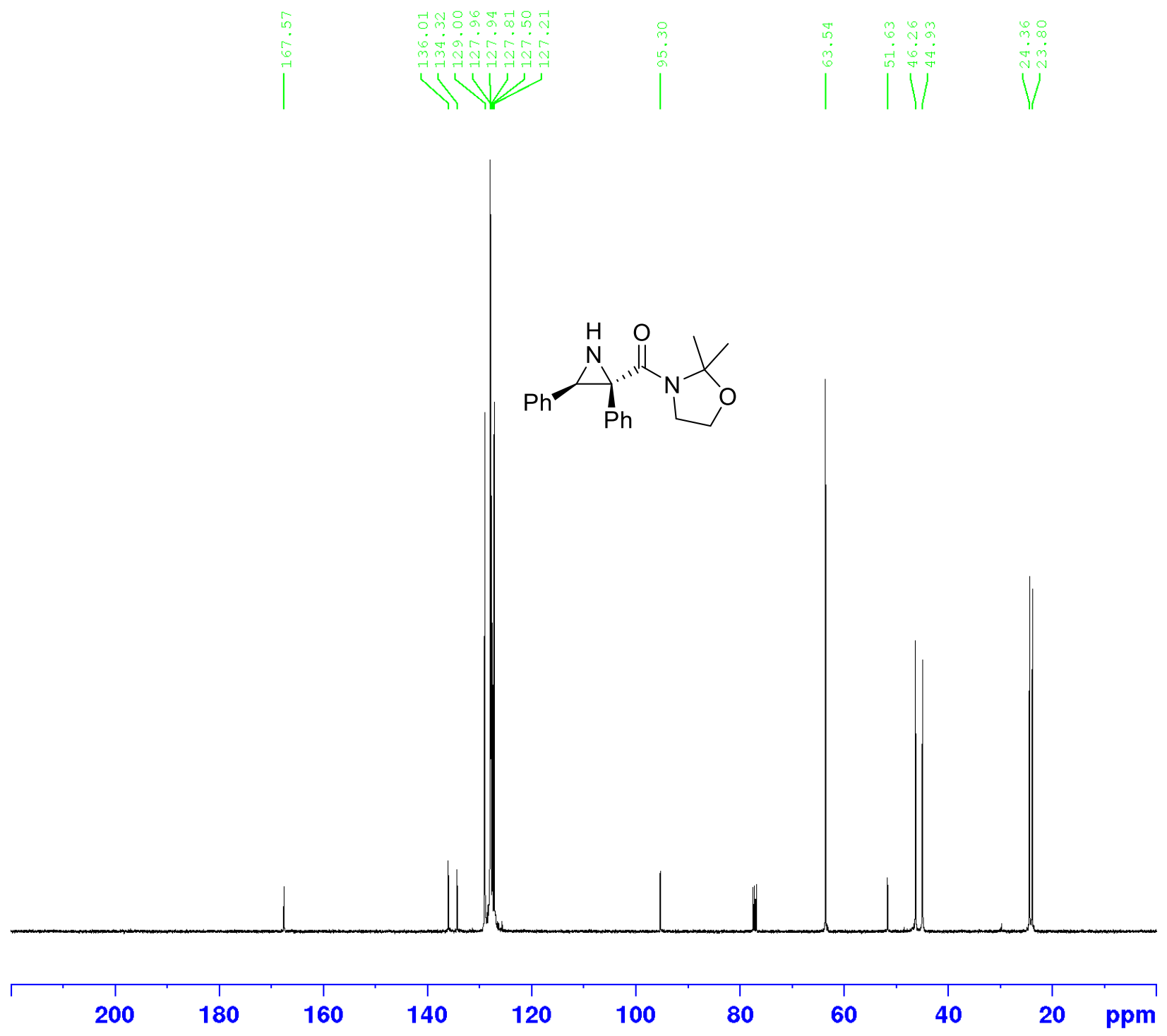


(13): ${ }^{1} \mathrm{H}$ NMR (400 MHz) in $\mathrm{CDCl}_{3}$

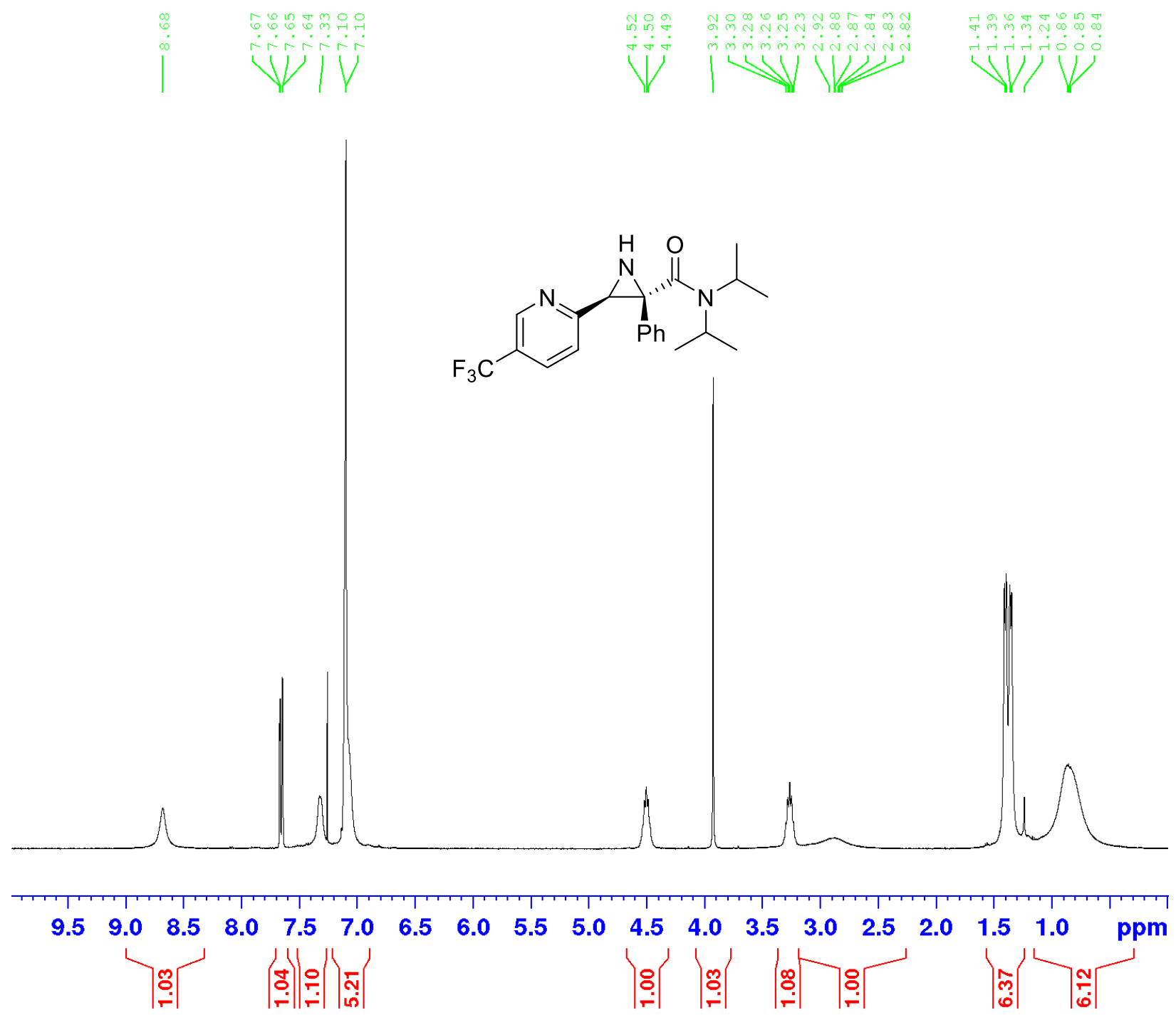


(13): ${ }^{13} \mathrm{C}$ NMR (100 MHz) in $\mathrm{CDCl}_{3}$

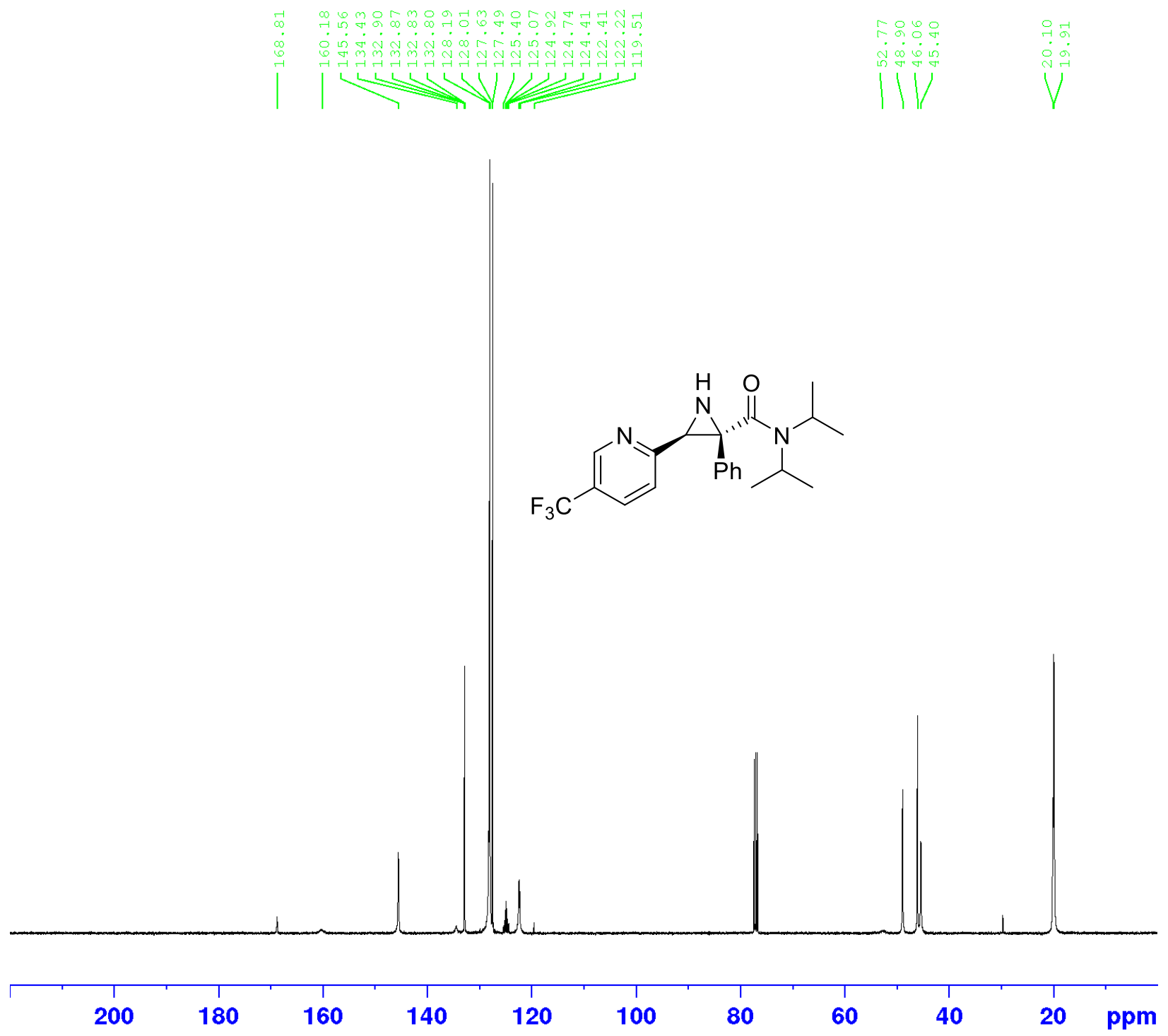


(15): ${ }^{1} \mathrm{H}$ NMR (400 MHz) in $\mathrm{CDCl}_{3}$

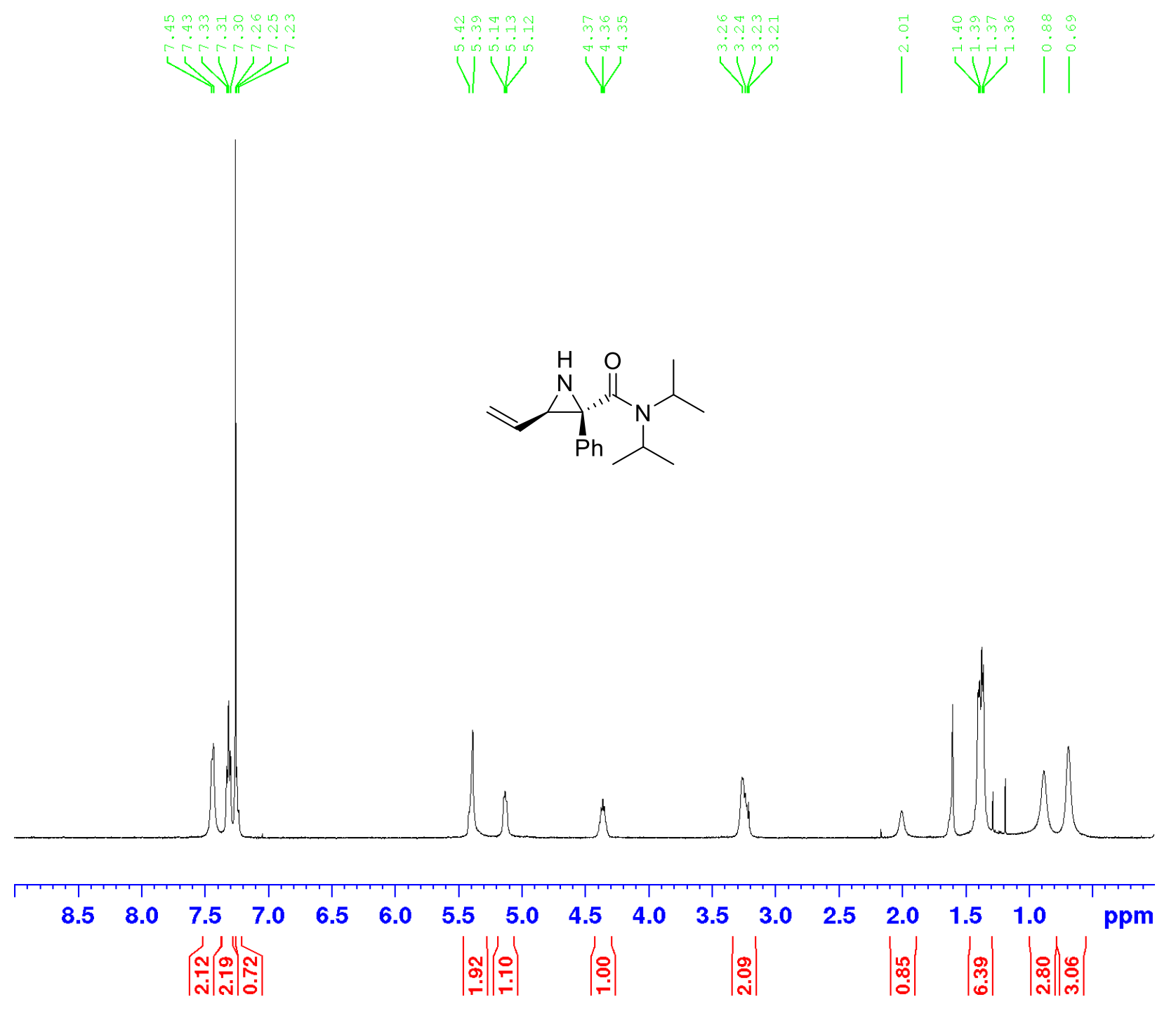


(15): ${ }^{13} \mathrm{C}$ NMR (100 MHz) in $\mathrm{CDCl}_{3}$

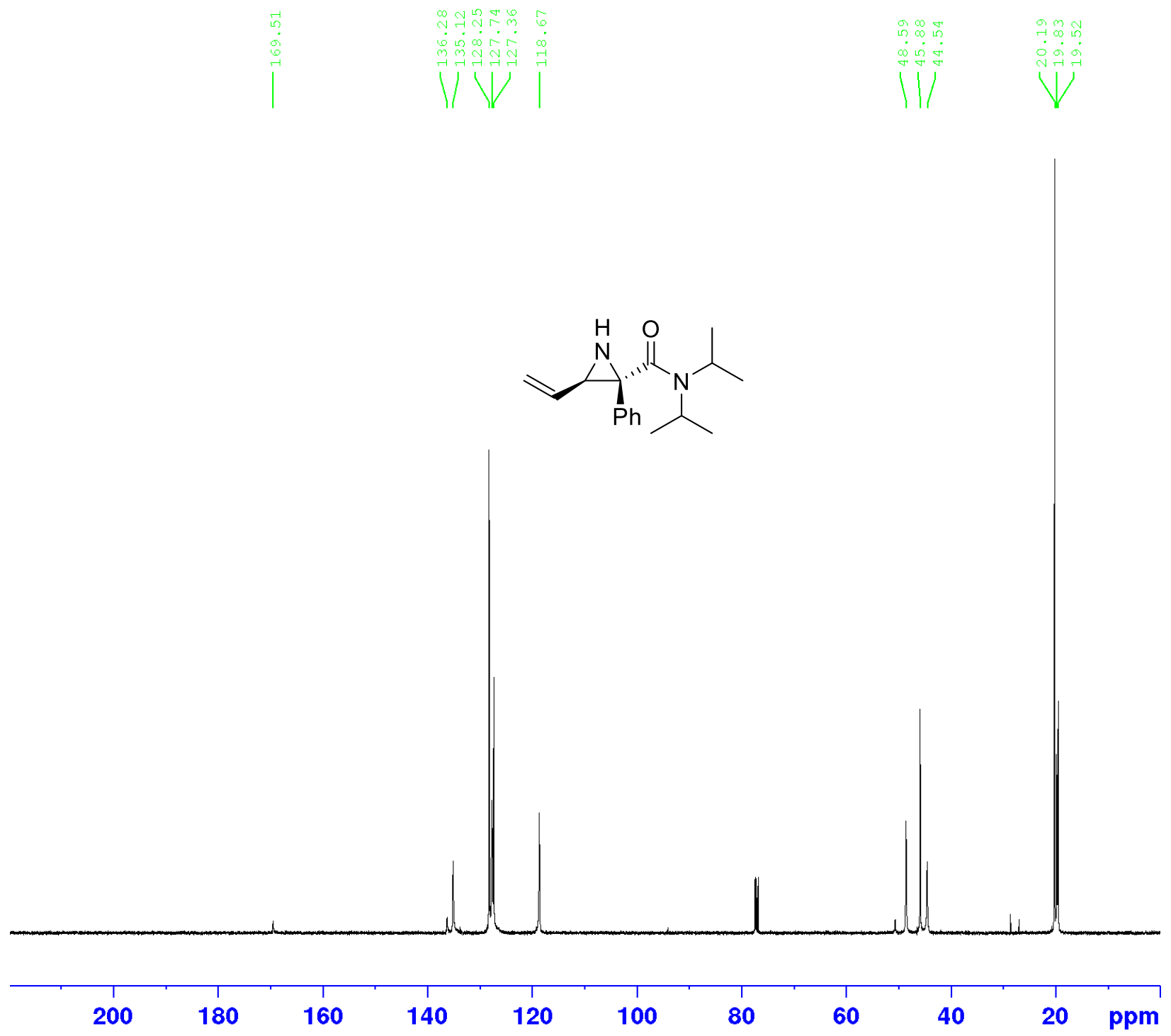


(17): ${ }^{1} \mathrm{H}$ NMR (400 MHz) in $\mathrm{CDCl}_{3}$

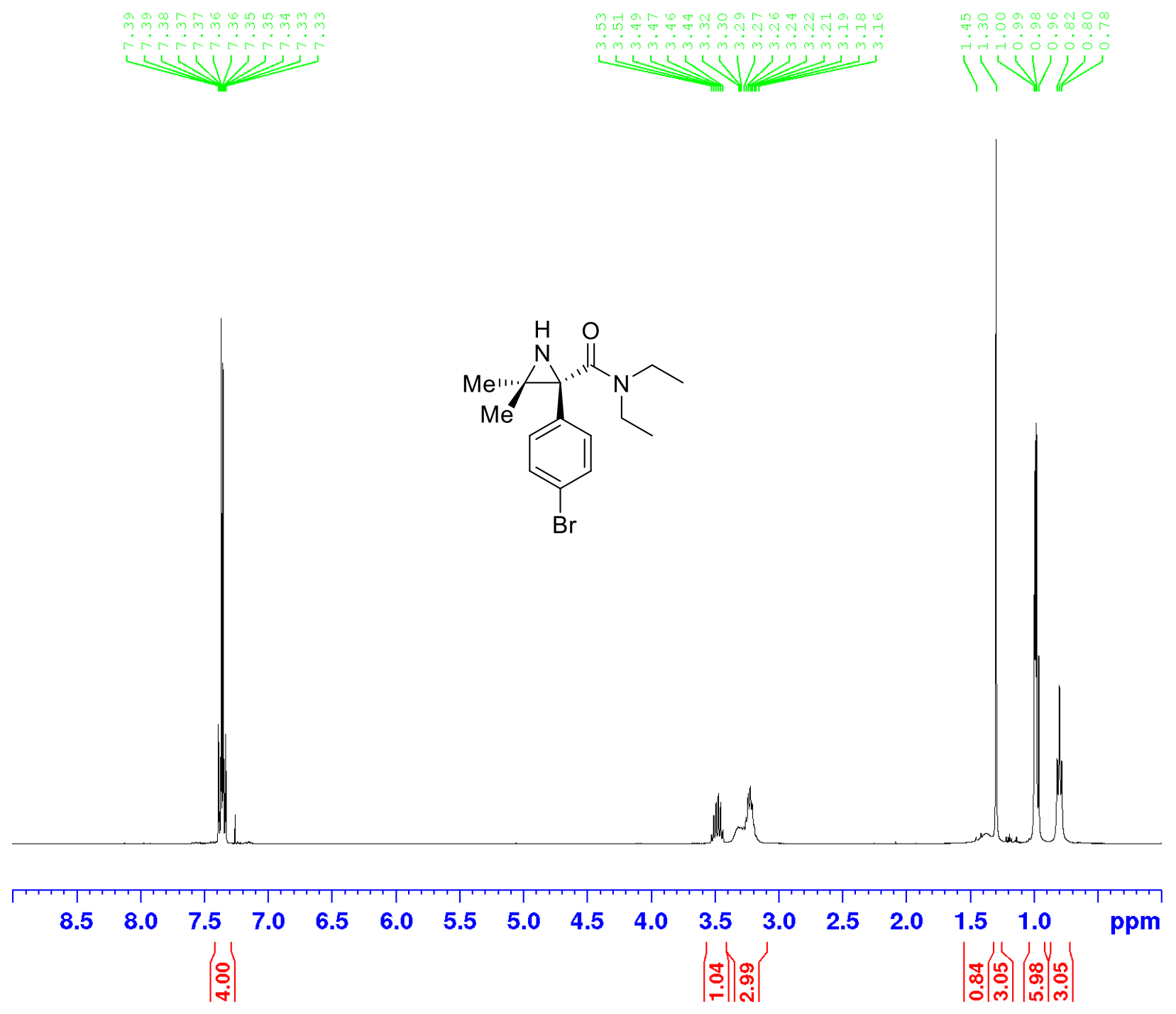


(17): ${ }^{13} \mathrm{C}$ NMR (100 MHz) in $\mathrm{CDCl}_{3}$

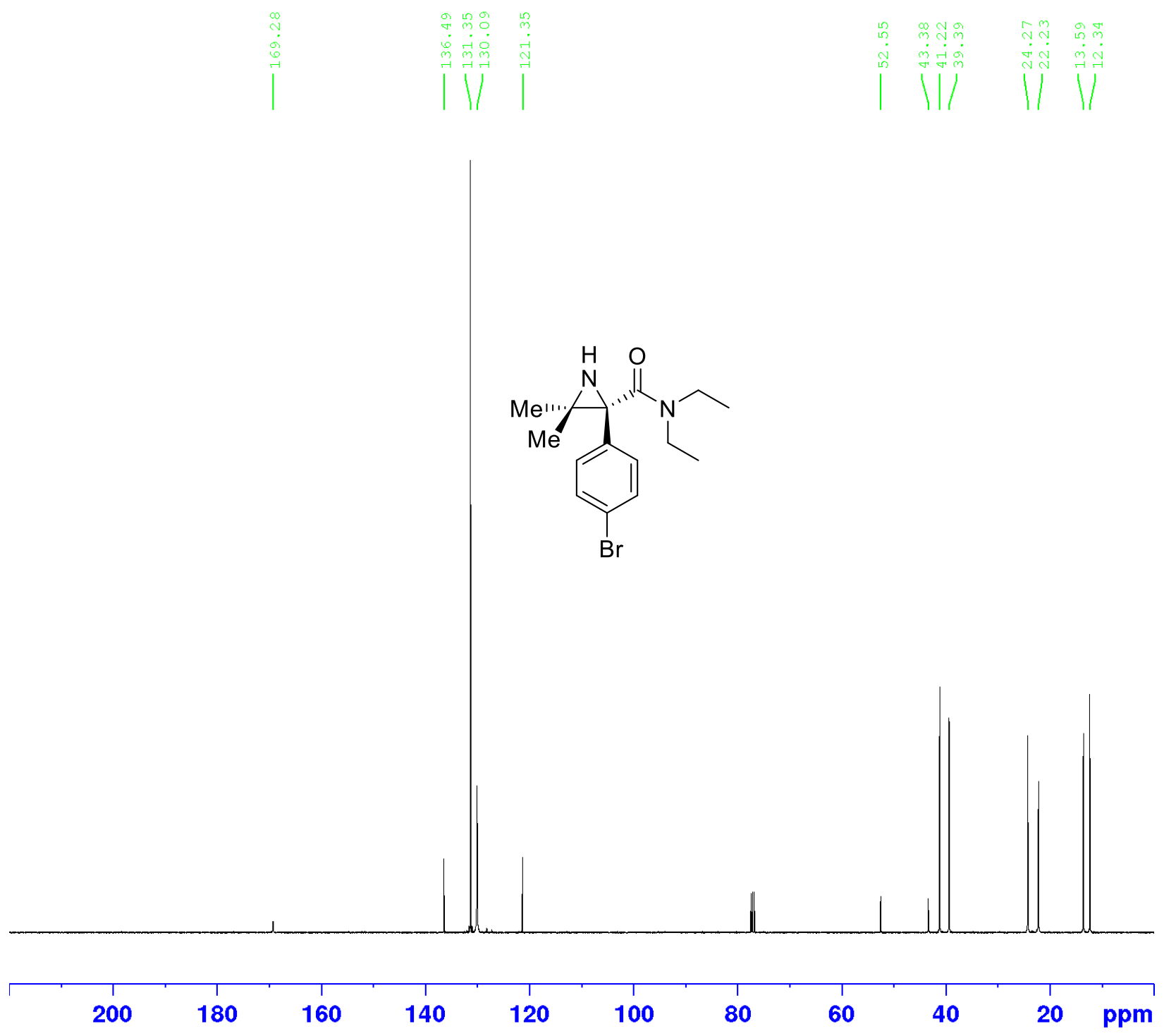


(19): ${ }^{1} \mathrm{H}$ NMR $(400 \mathrm{MHz})$ in $\mathrm{C}_{6} \mathrm{D}_{6}$

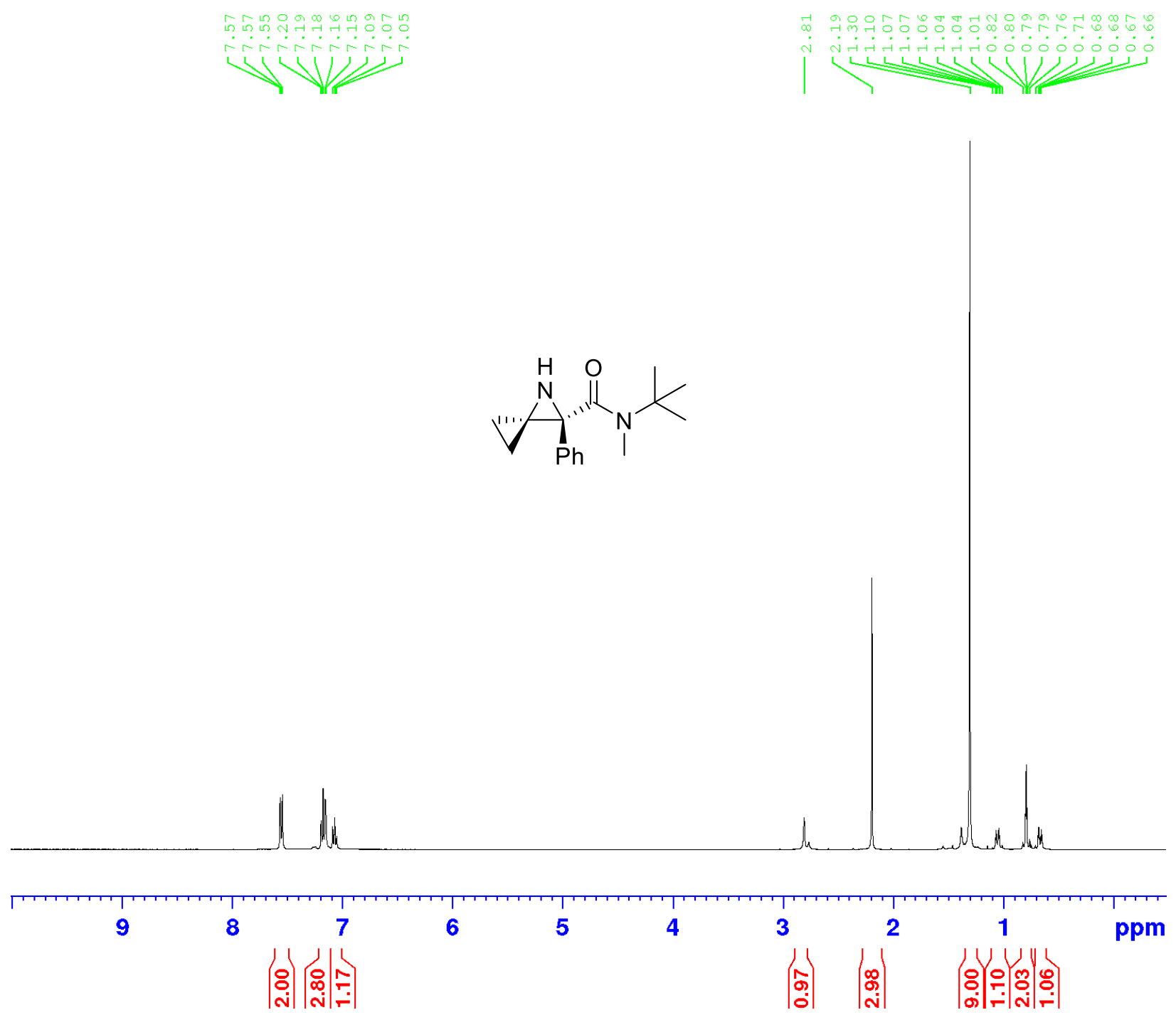


(19): ${ }^{13} \mathrm{C}$ NMR (100 MHz) in $\mathrm{C}_{6} \mathrm{D}_{6}$

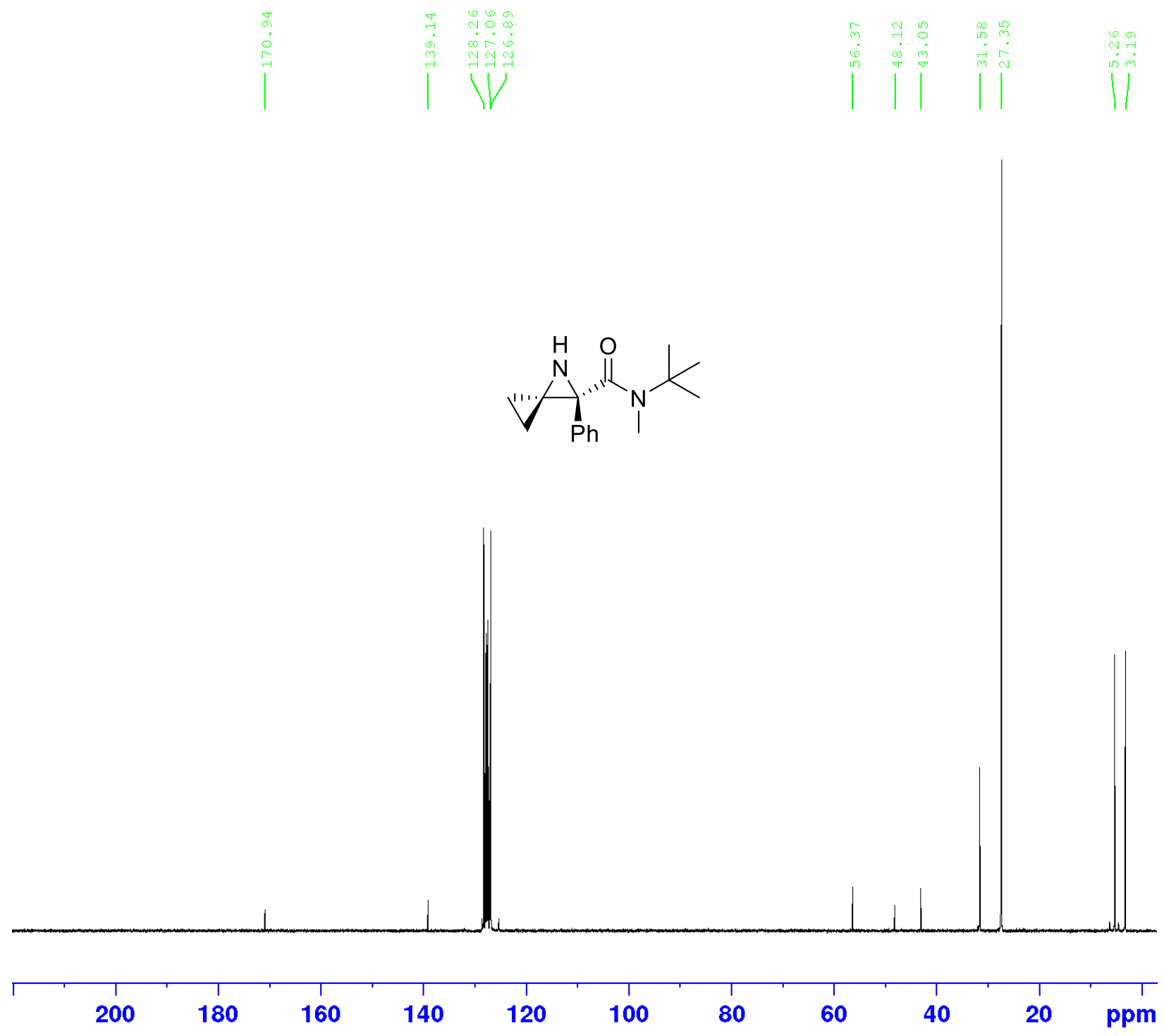


(21): ${ }^{1} \mathrm{H}$ NMR (400 MHz) in $\mathrm{CDCl}_{3}$
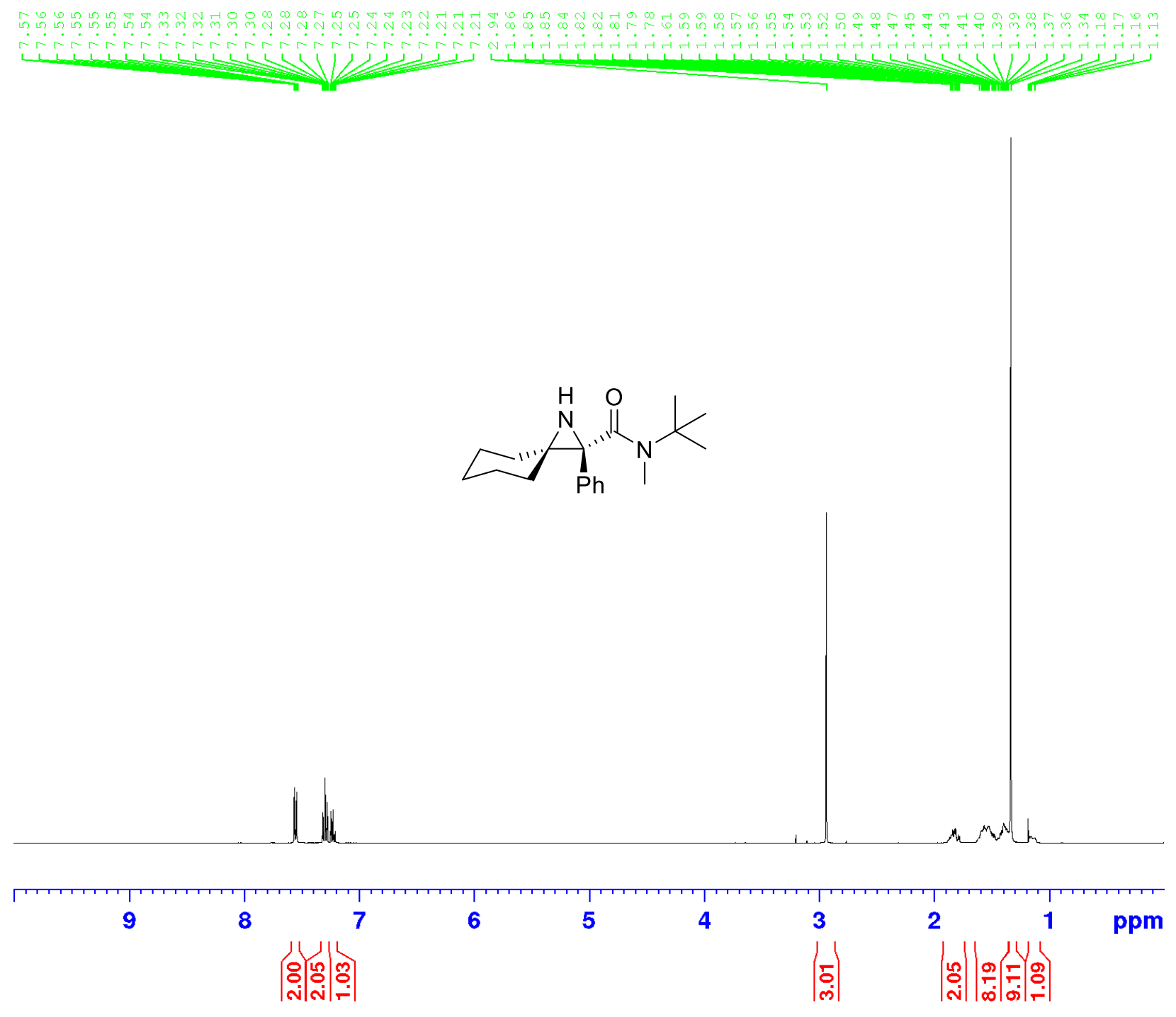
(21): ${ }^{13} \mathrm{C}$ NMR (100 MHz) in $\mathrm{CDCl}_{3}$

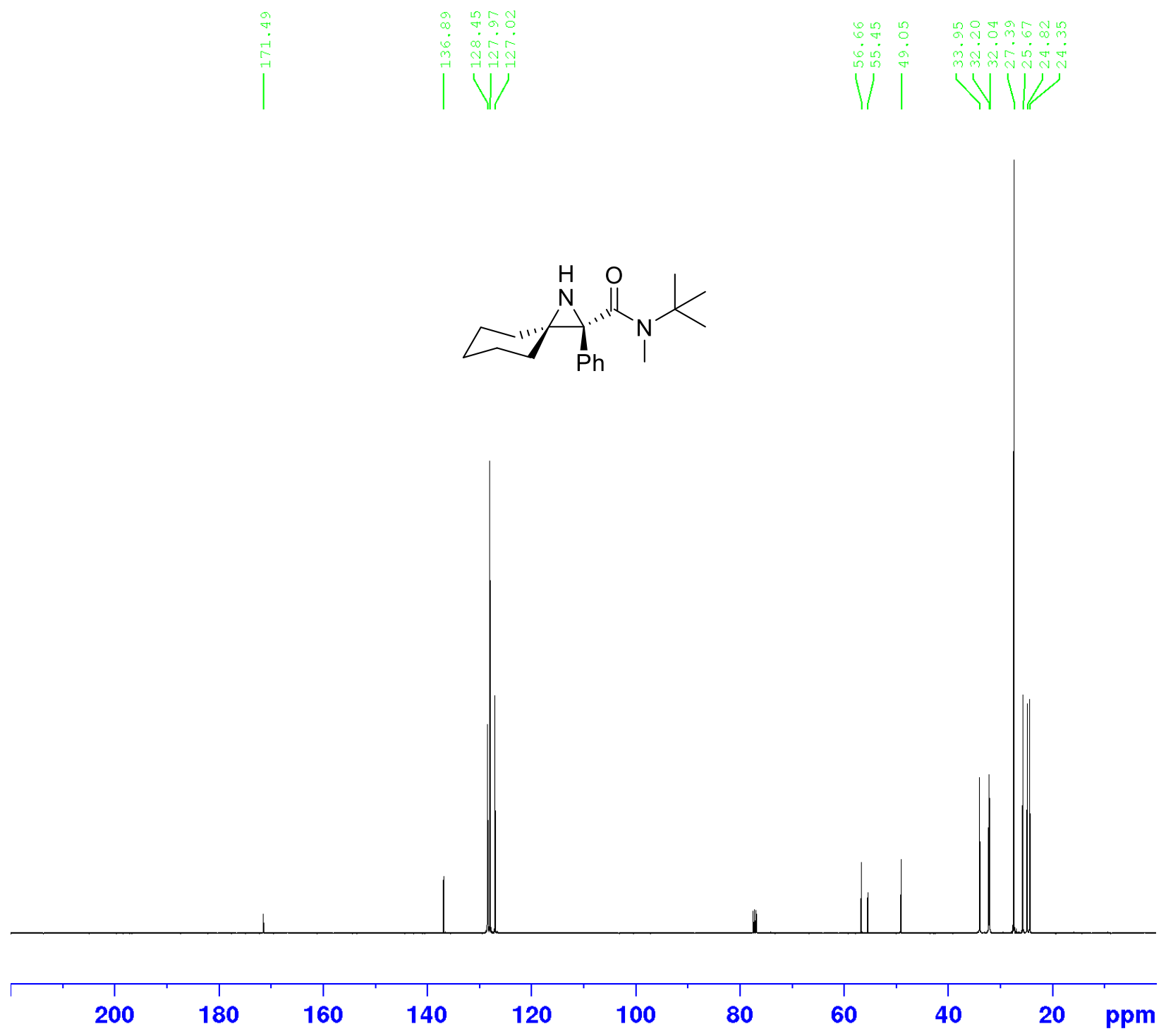


(22): ${ }^{1} \mathrm{H}$ NMR $(400 \mathrm{MHz})$ in $\mathrm{CDCl}_{3}$

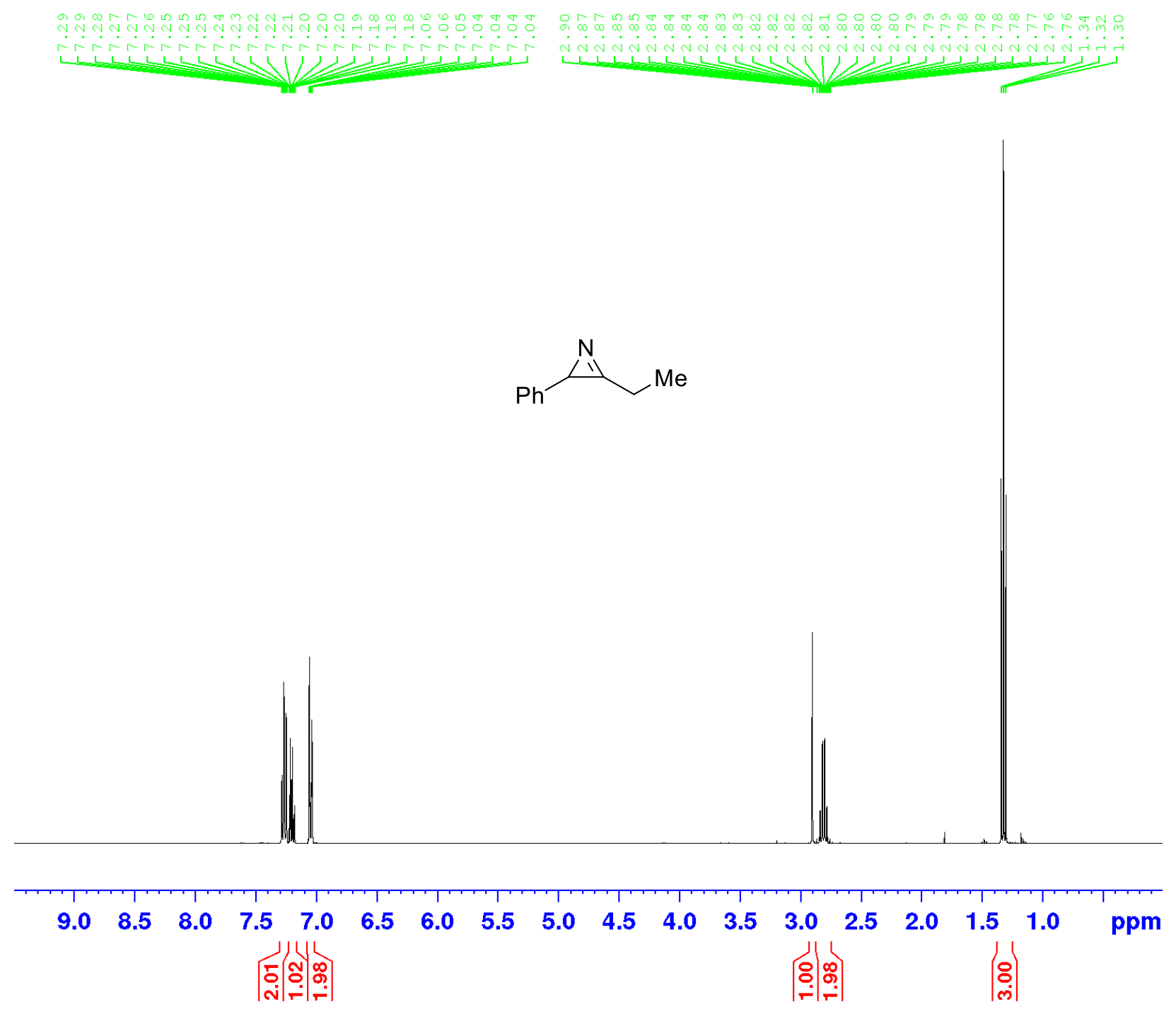


(22): ${ }^{13} \mathrm{C} \mathrm{NMR}(100 \mathrm{MHz})$ in $\mathrm{CDCl}_{3}$

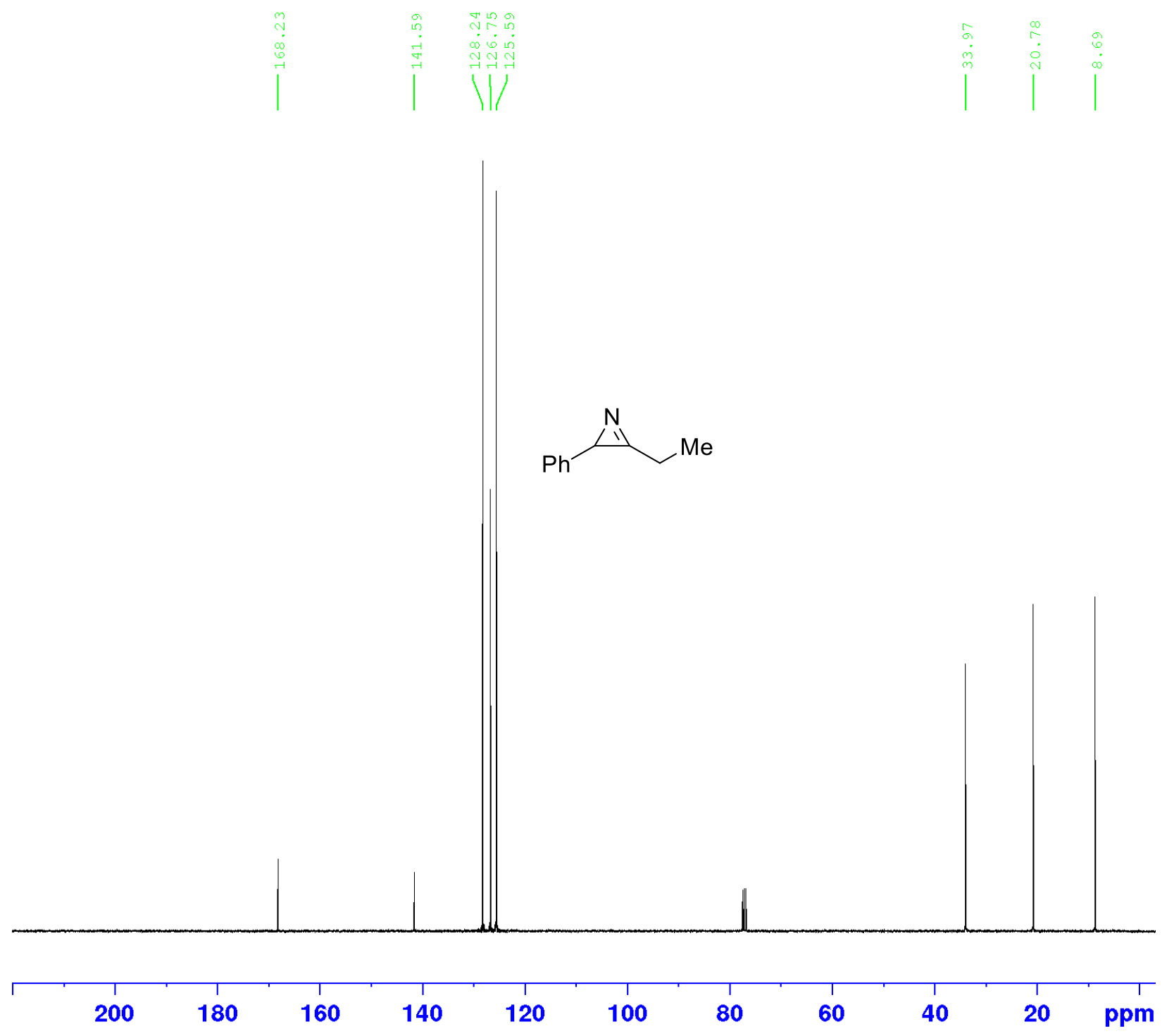


(23): ${ }^{1} \mathrm{H}$ NMR $(400 \mathrm{MHz})$ in $\mathrm{CDCl}_{3}$

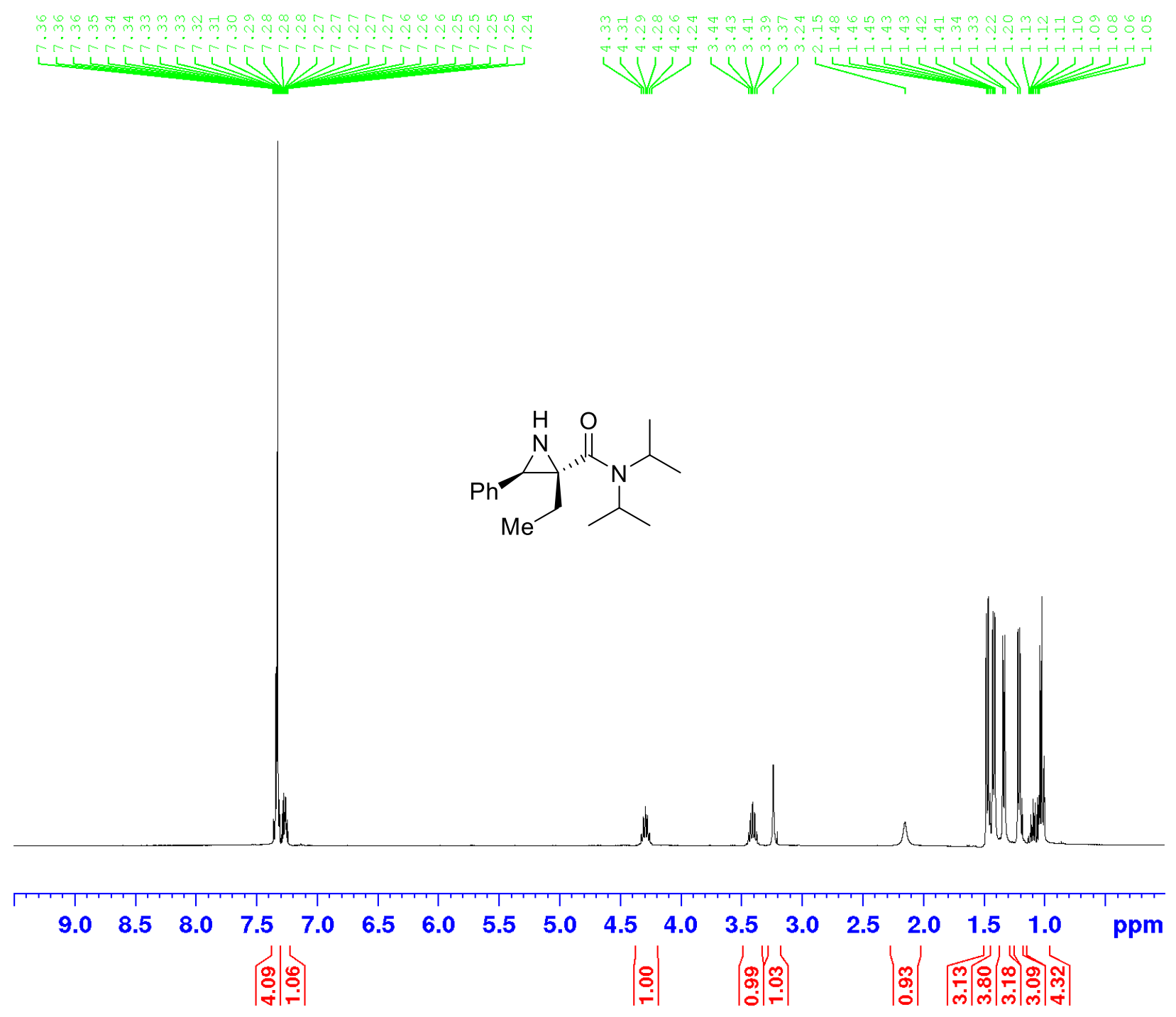


(23): ${ }^{13} \mathrm{C}$ NMR (100 MHz) in $\mathrm{CDCl}_{3}$

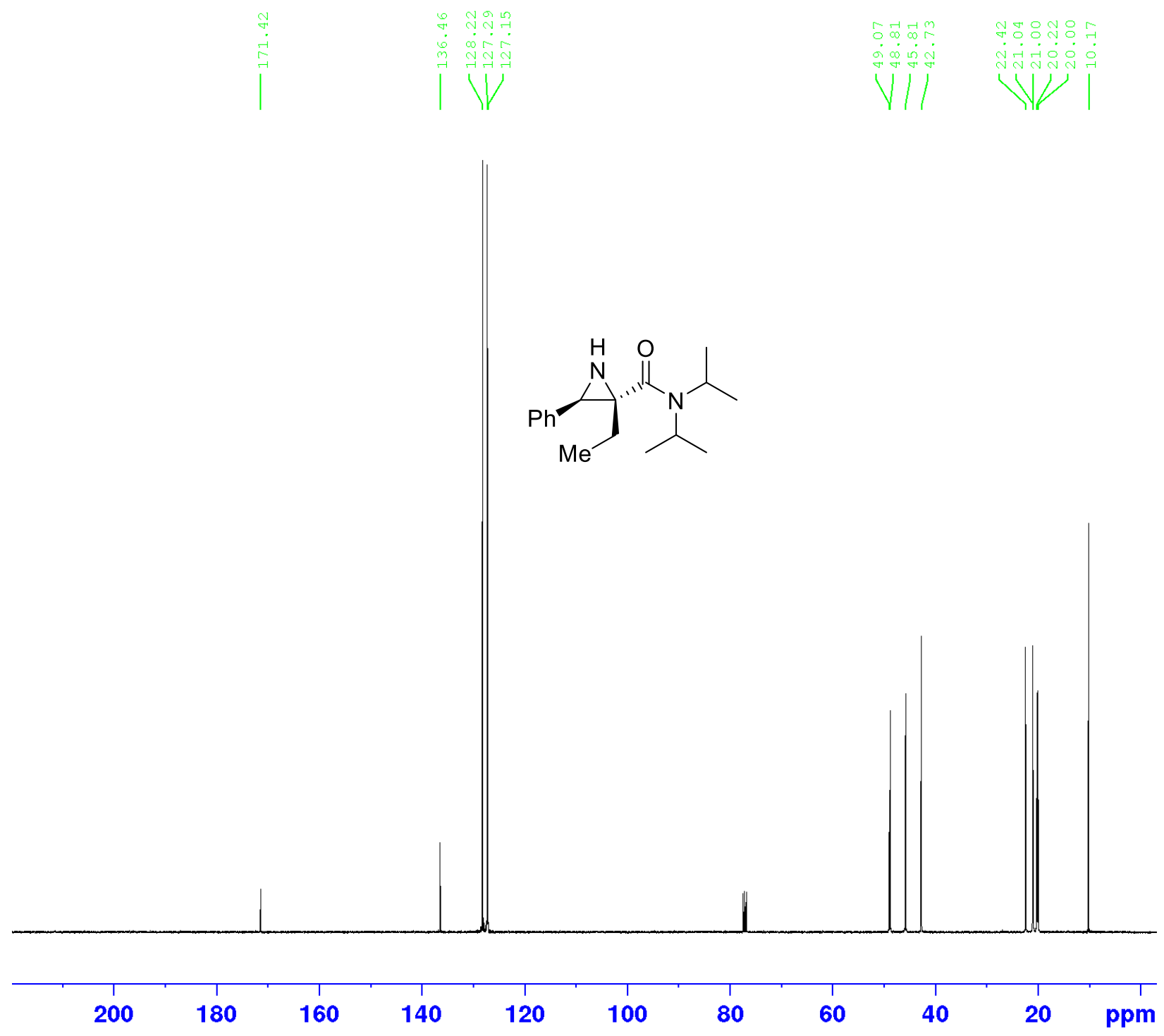


(2-(4-chlorophenyl)-1-cyclopropylethan-1-one oxime): ${ }^{1} \mathrm{H} \mathrm{NMR}(400 \mathrm{MHz})$ in $\mathrm{CDCl}_{3}$

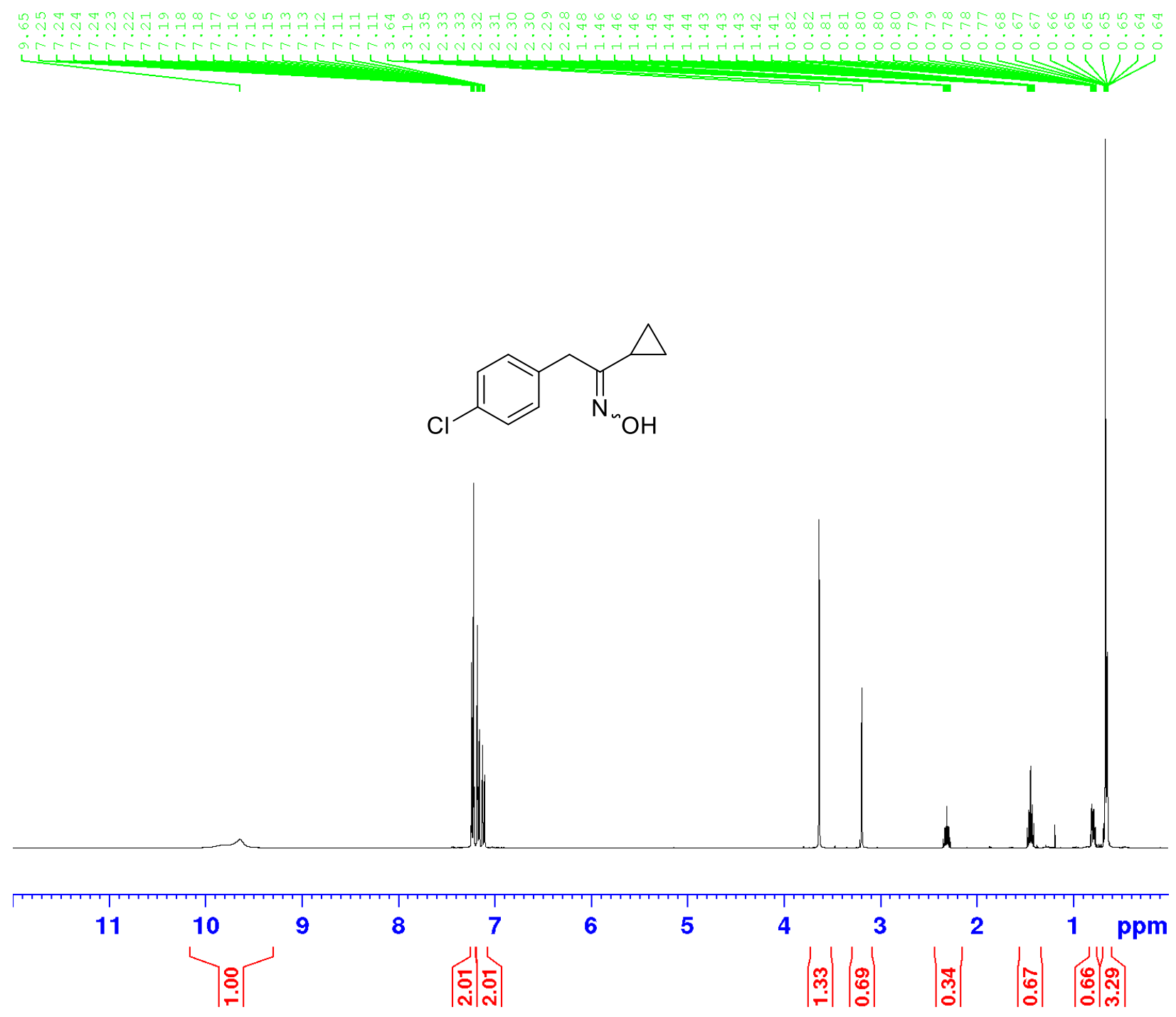


(2-(4-chlorophenyl)-1-cyclopropylethan-1-one oxime): ${ }^{13} \mathrm{C} \mathrm{NMR} \mathrm{(100} \mathrm{MHz)} \mathrm{in} \mathrm{CDCl}_{3}$

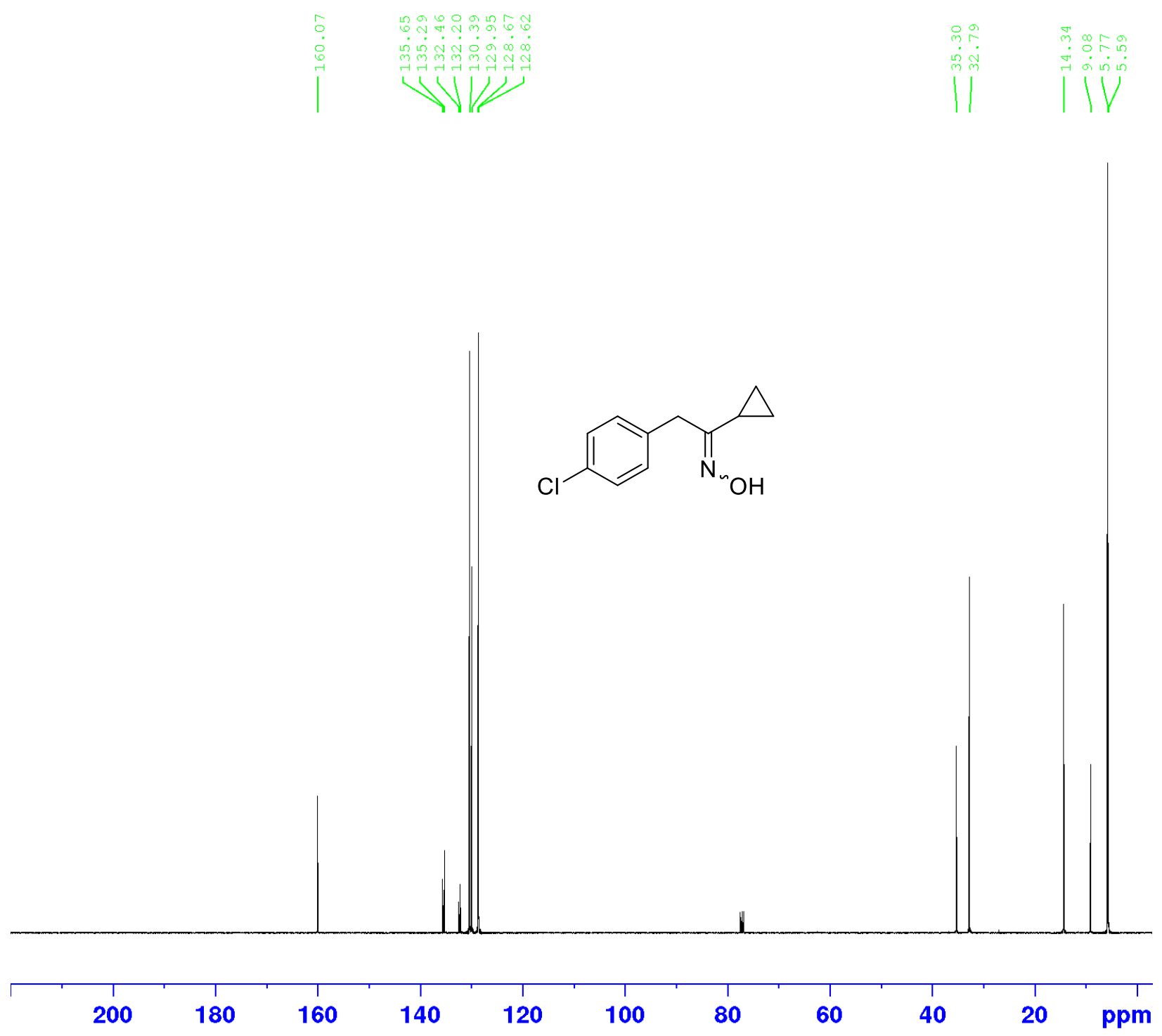


(24): ${ }^{1} \mathrm{H} \mathrm{NMR}(400 \mathrm{MHz})$ in $\mathrm{CDCl}_{3}$
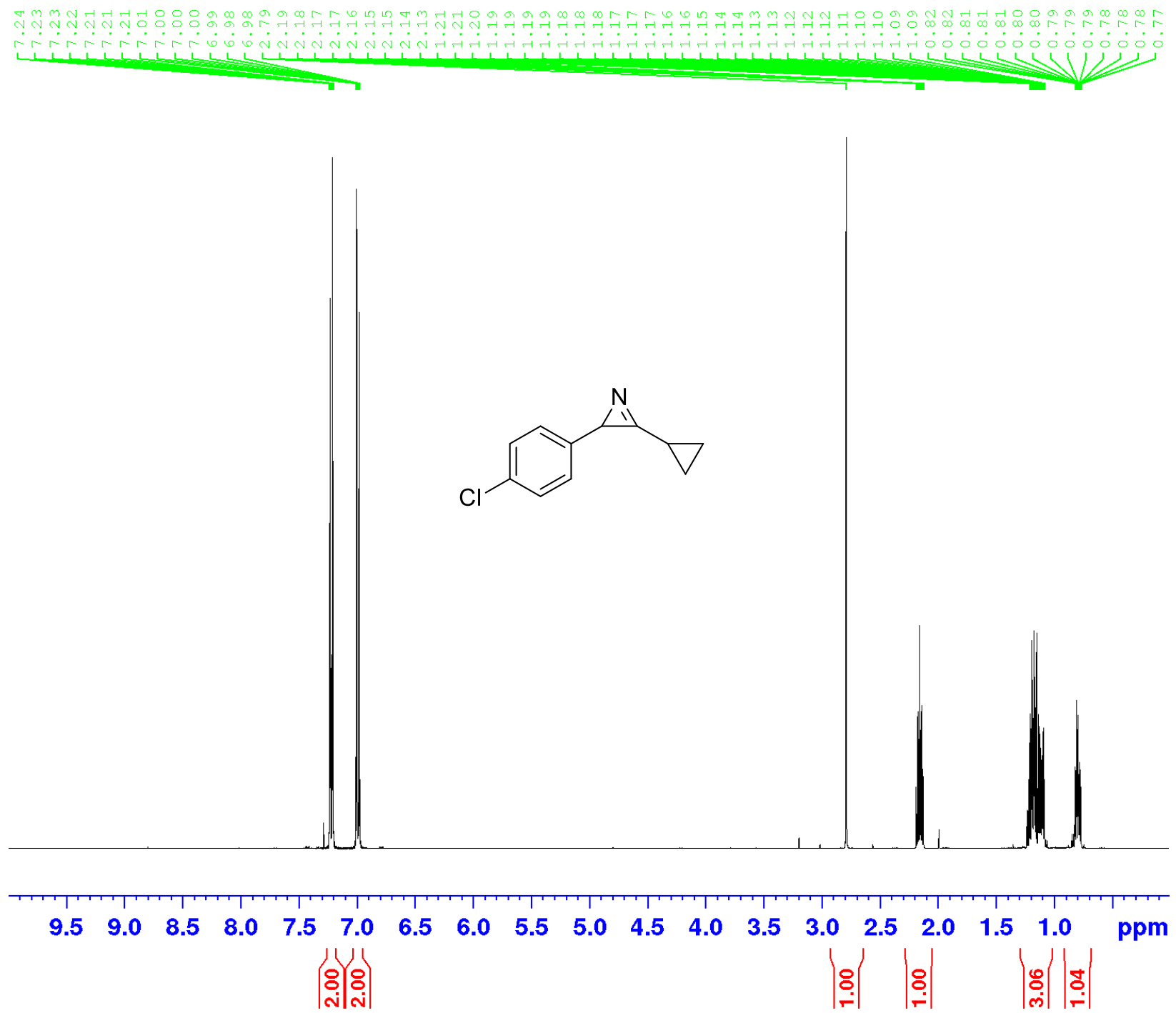
(24): ${ }^{13} \mathrm{C}$ NMR (100 MHz) in $\mathrm{CDCl}_{3}$

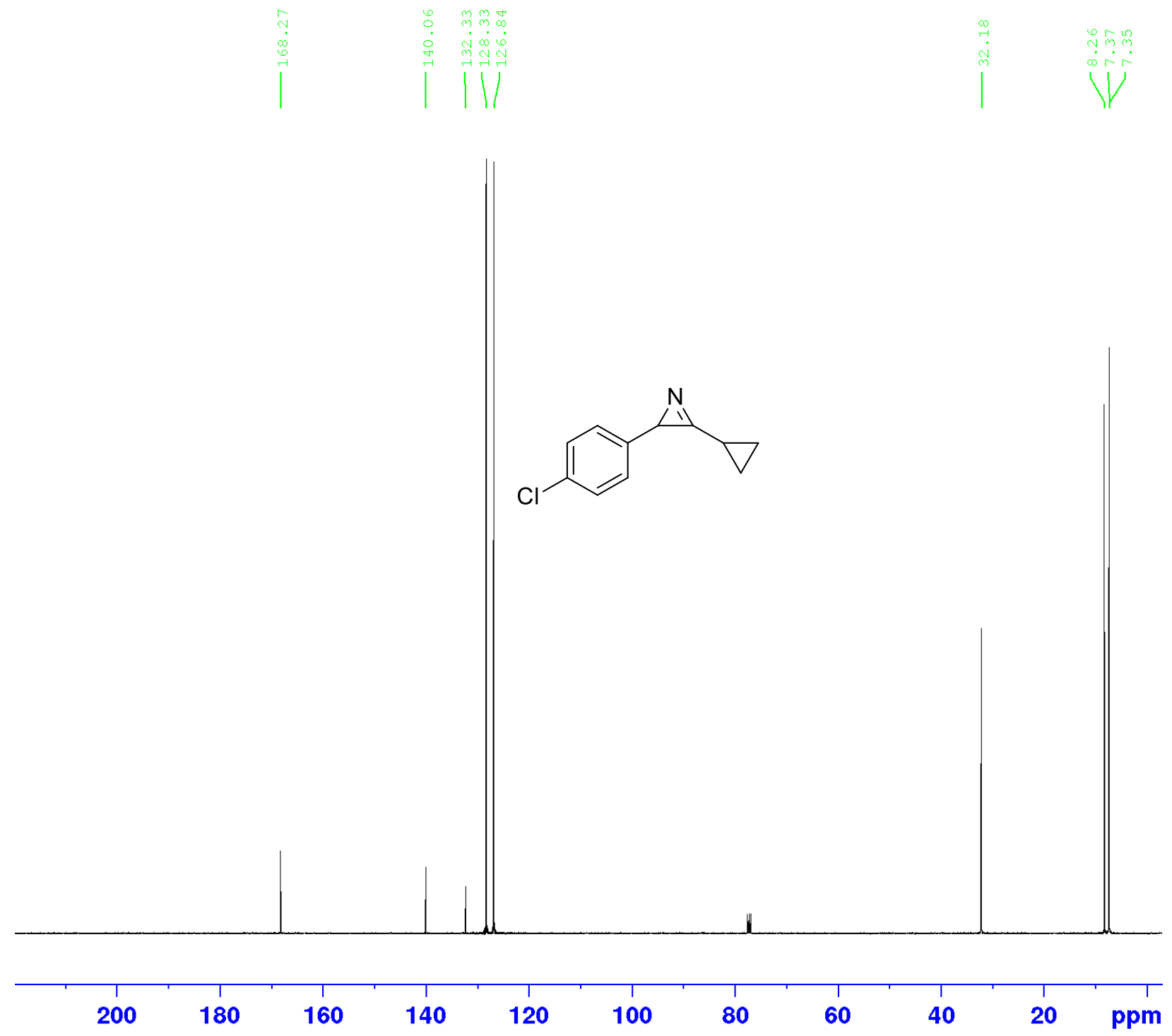


(25): ${ }^{1} \mathrm{H}$ NMR (400 MHz) in $\mathrm{CDCl}_{3}$

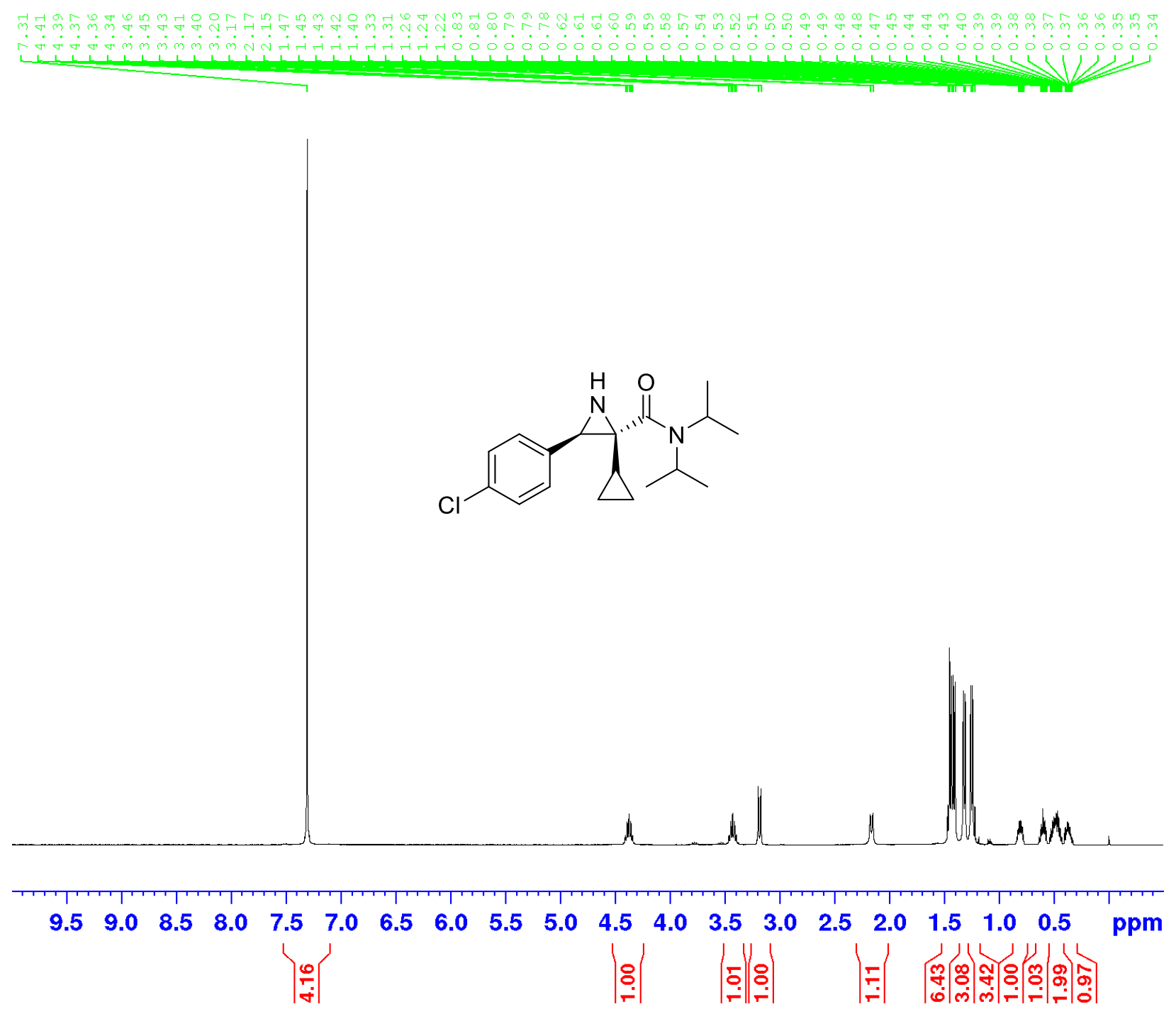


(25): ${ }^{13} \mathrm{C}$ NMR (100 MHz) in $\mathrm{CDCl}_{3}$

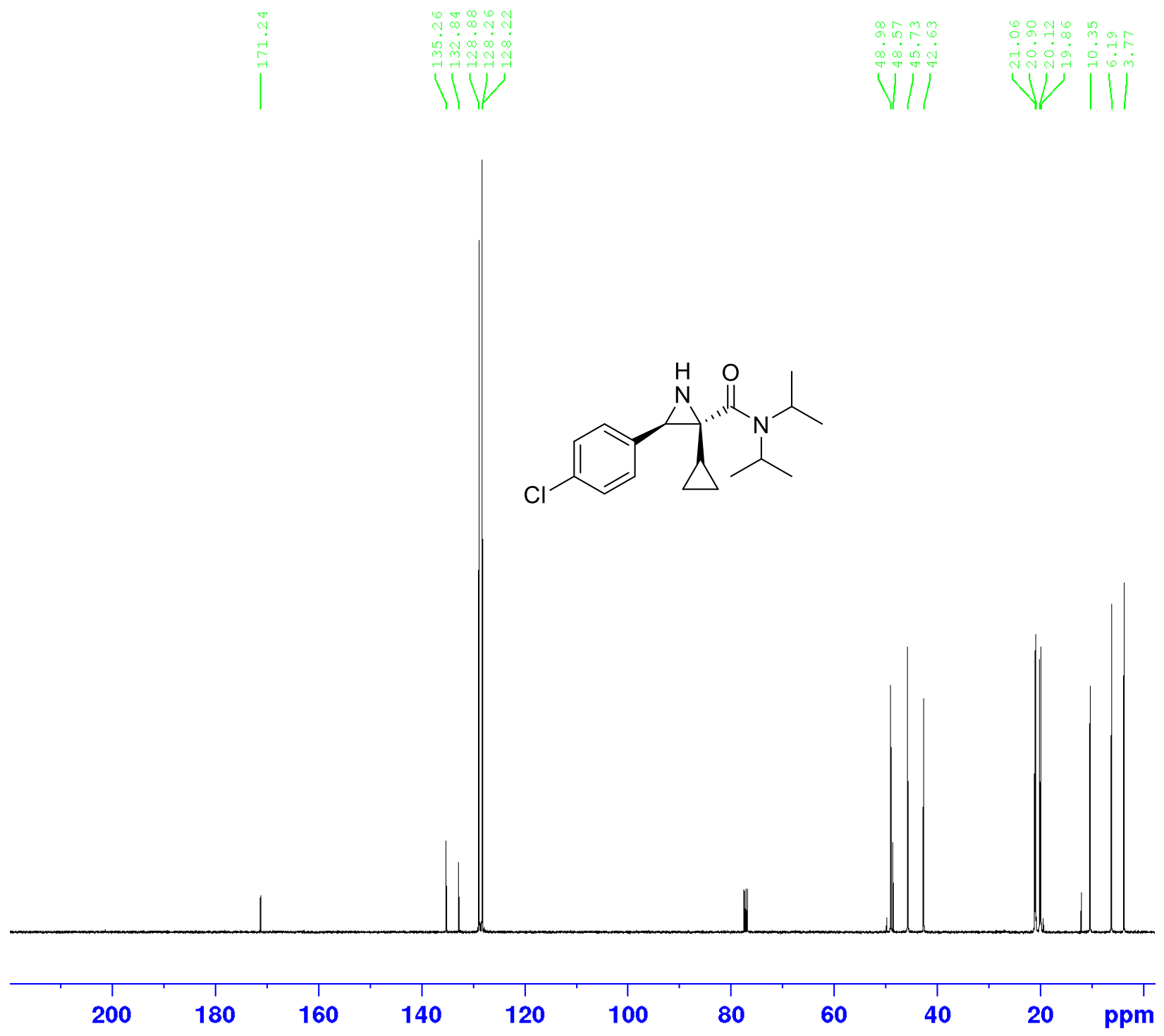


(27): ${ }^{1} \mathrm{H}$ NMR (400 MHz) in $\mathrm{CDCl}_{3}$

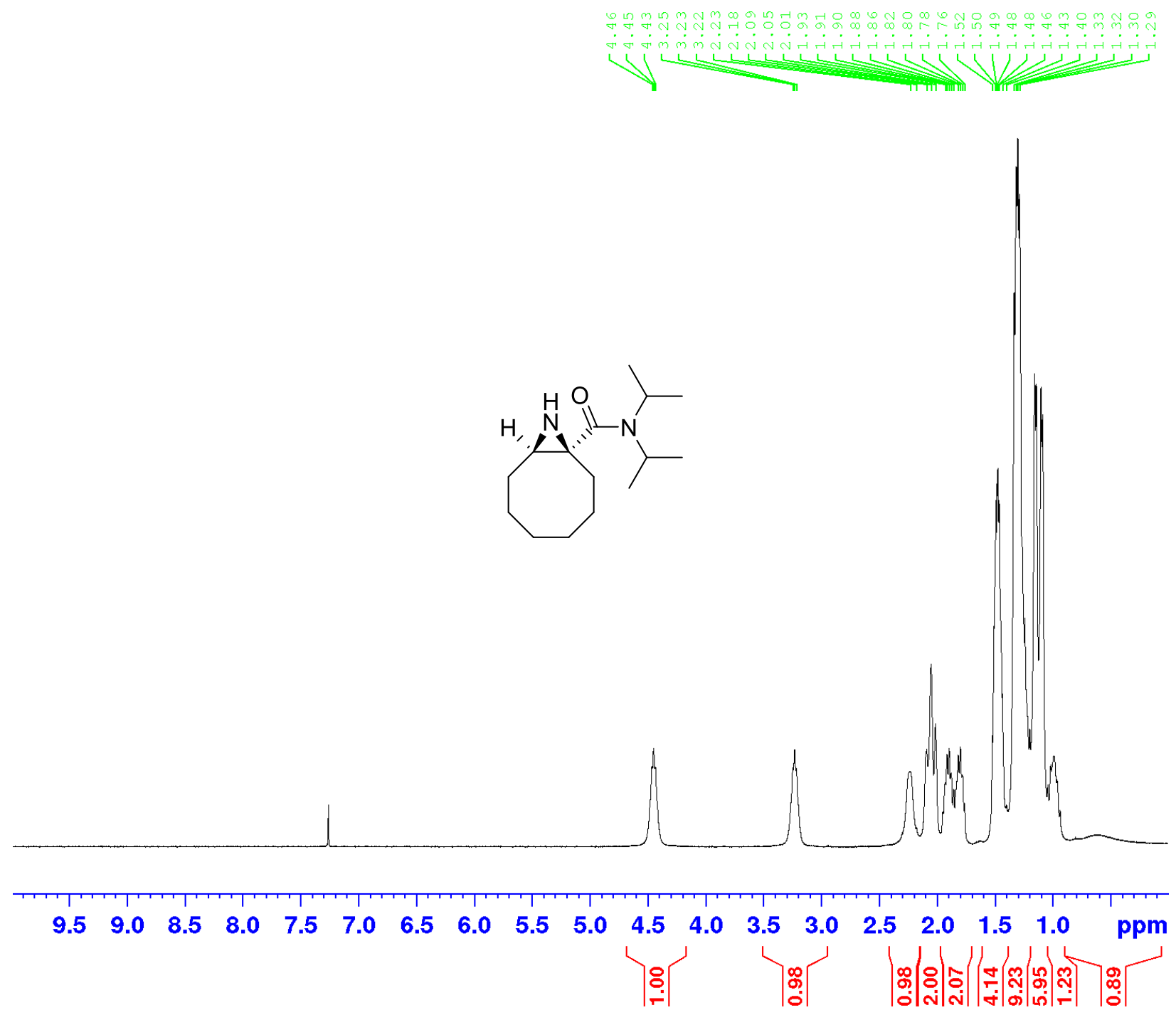


(27): ${ }^{13} \mathrm{C}$ NMR (100 MHz) in $\mathrm{CDCl}_{3}$

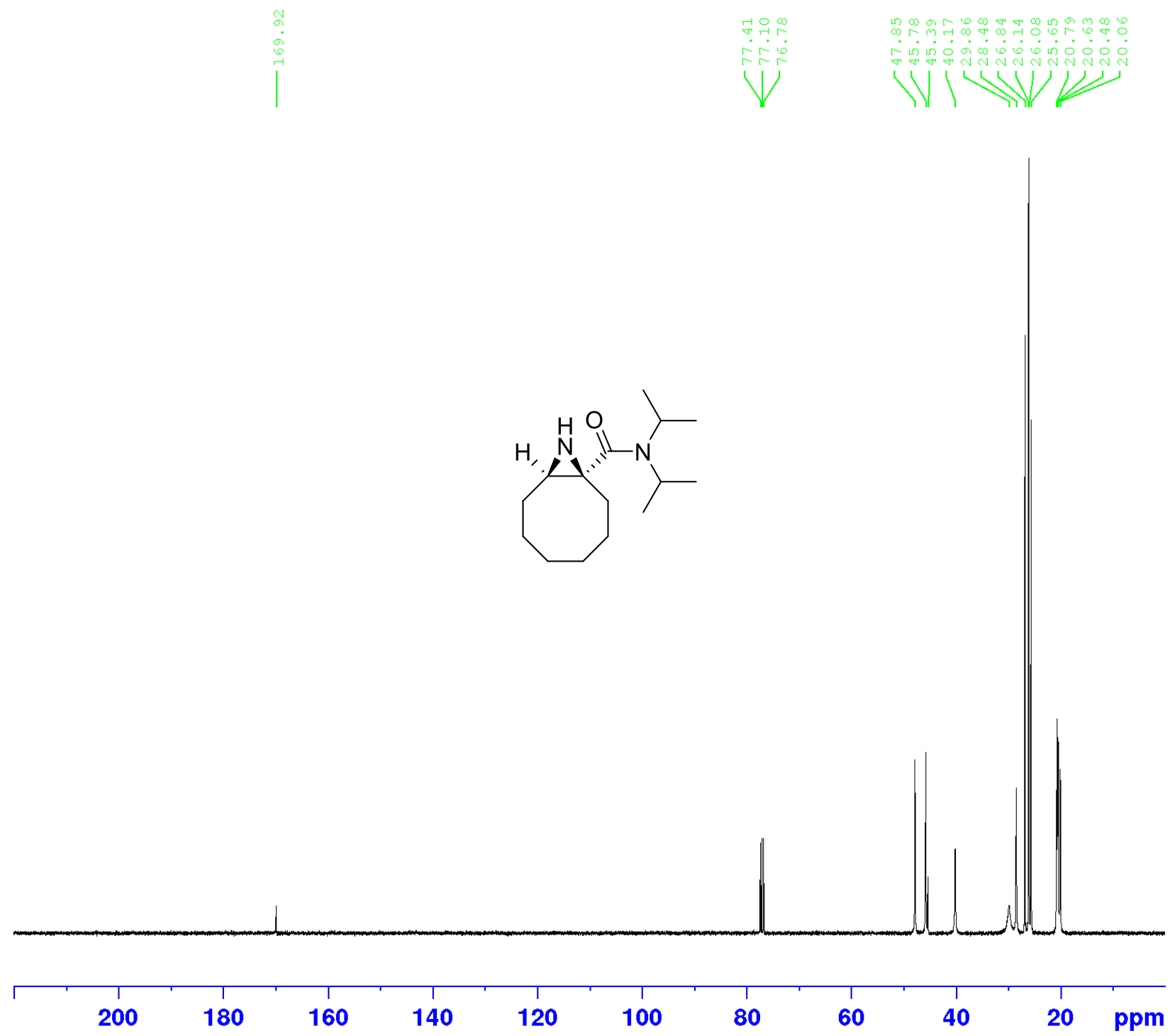


(29): ${ }^{1} \mathrm{H}$ NMR (400 MHz) in $\mathrm{CDCl}_{3}$

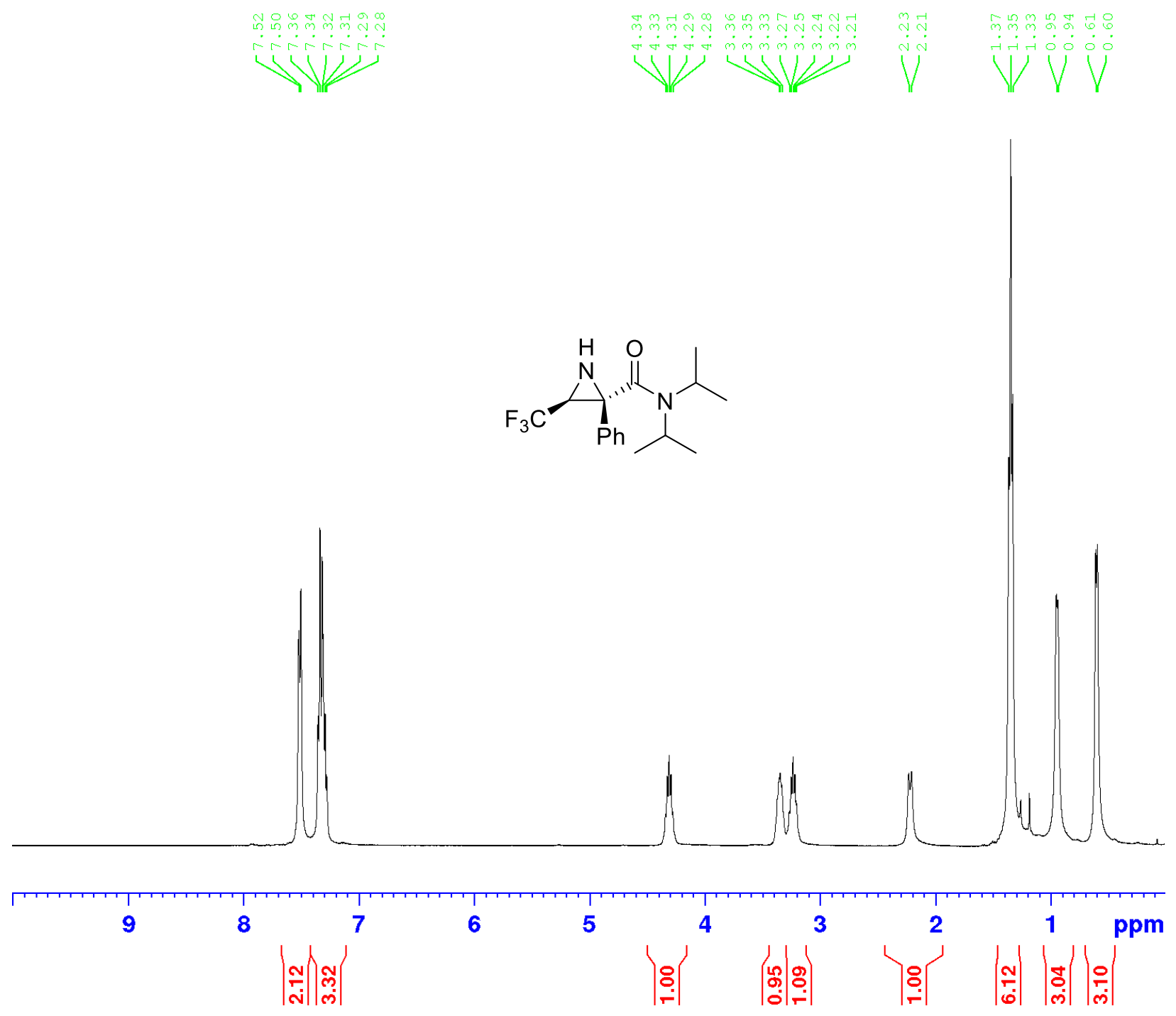


(29): ${ }^{13} \mathrm{C}$ NMR (100 MHz) in $\mathrm{CDCl}_{3}$

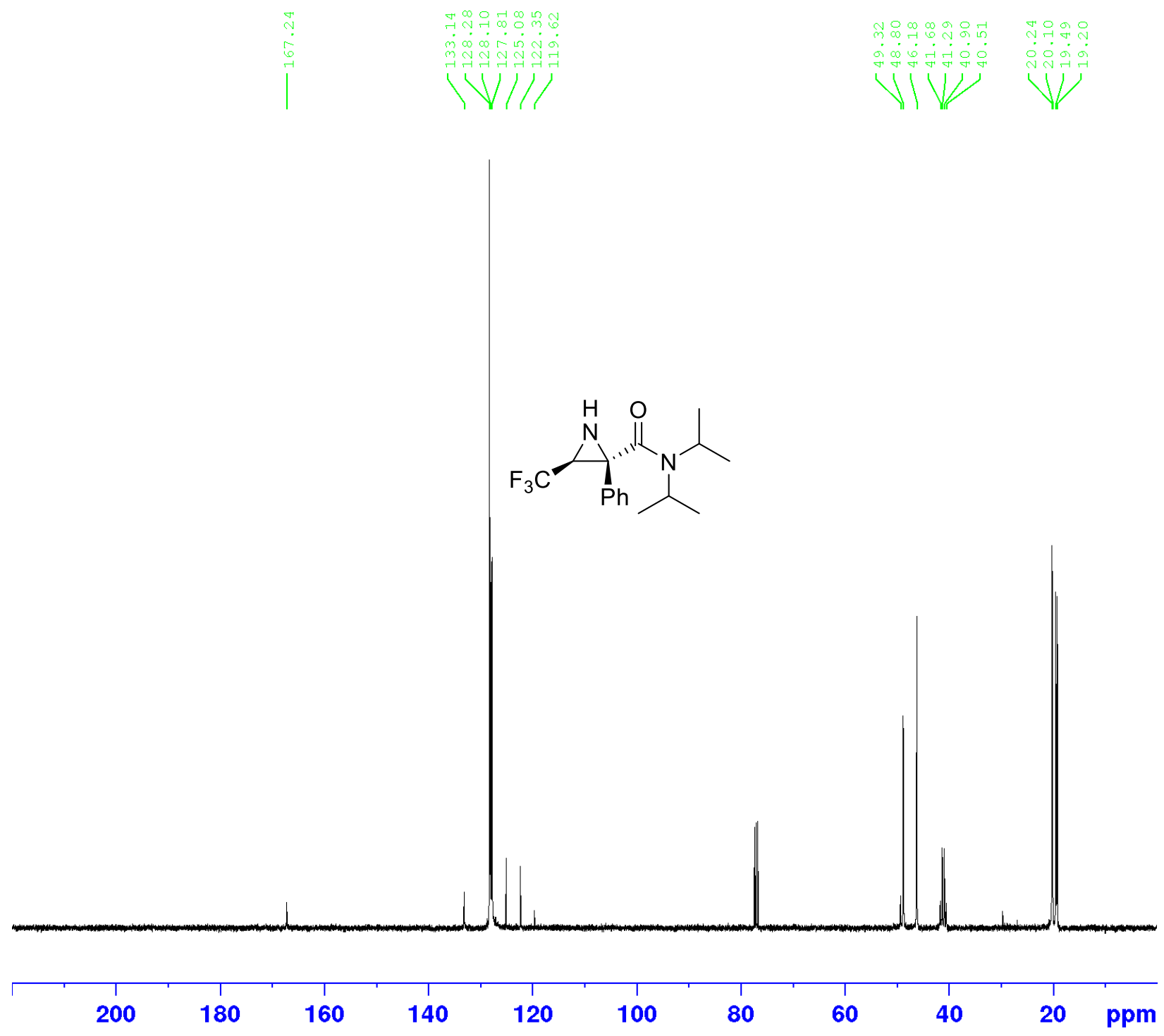


(33): ${ }^{1} \mathrm{H}$ NMR (400 MHz) in $\mathrm{CDCl}_{3}$

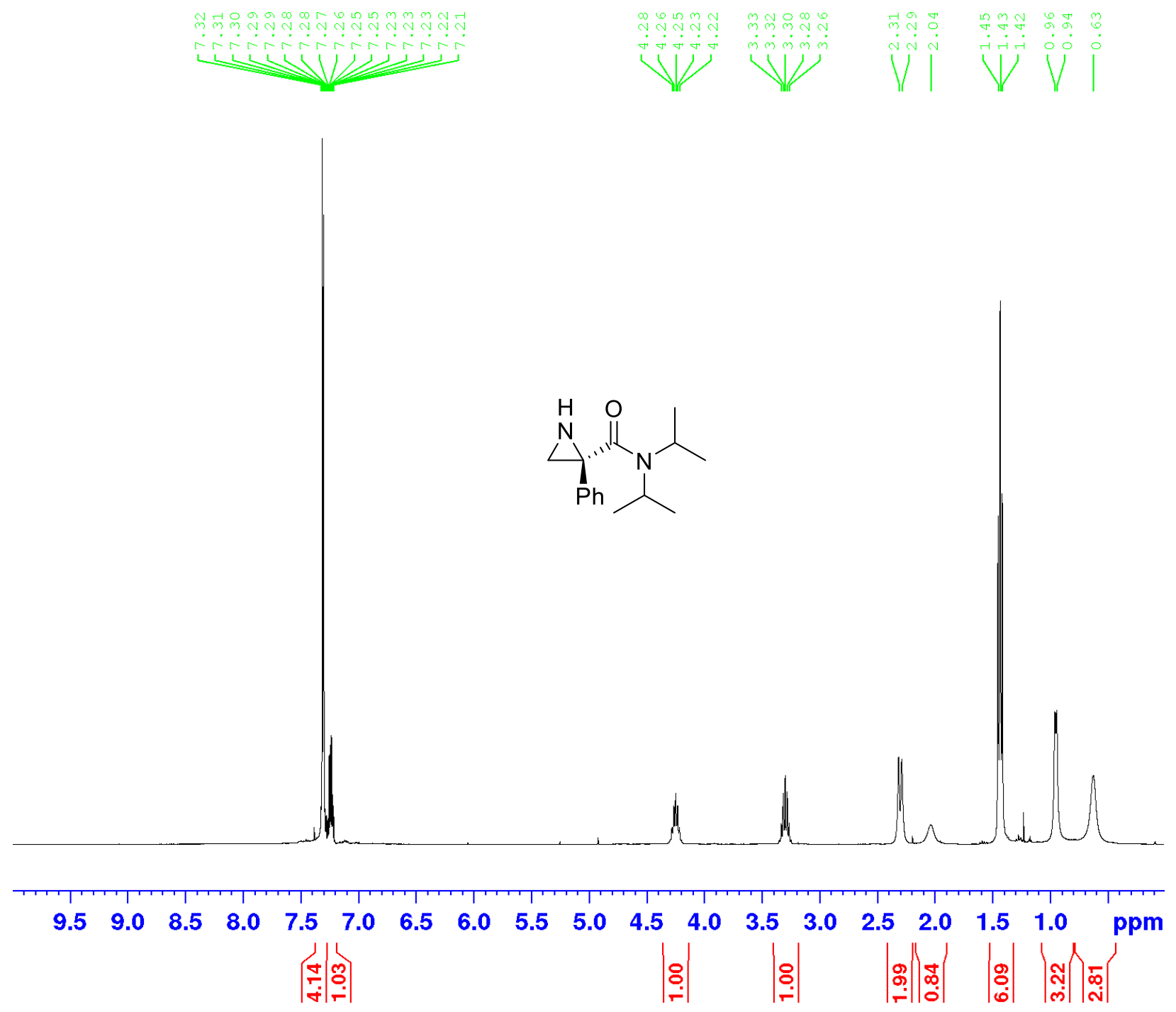


(33): ${ }^{13} \mathrm{C}$ NMR (100 MHz) in $\mathrm{CDCl}_{3}$

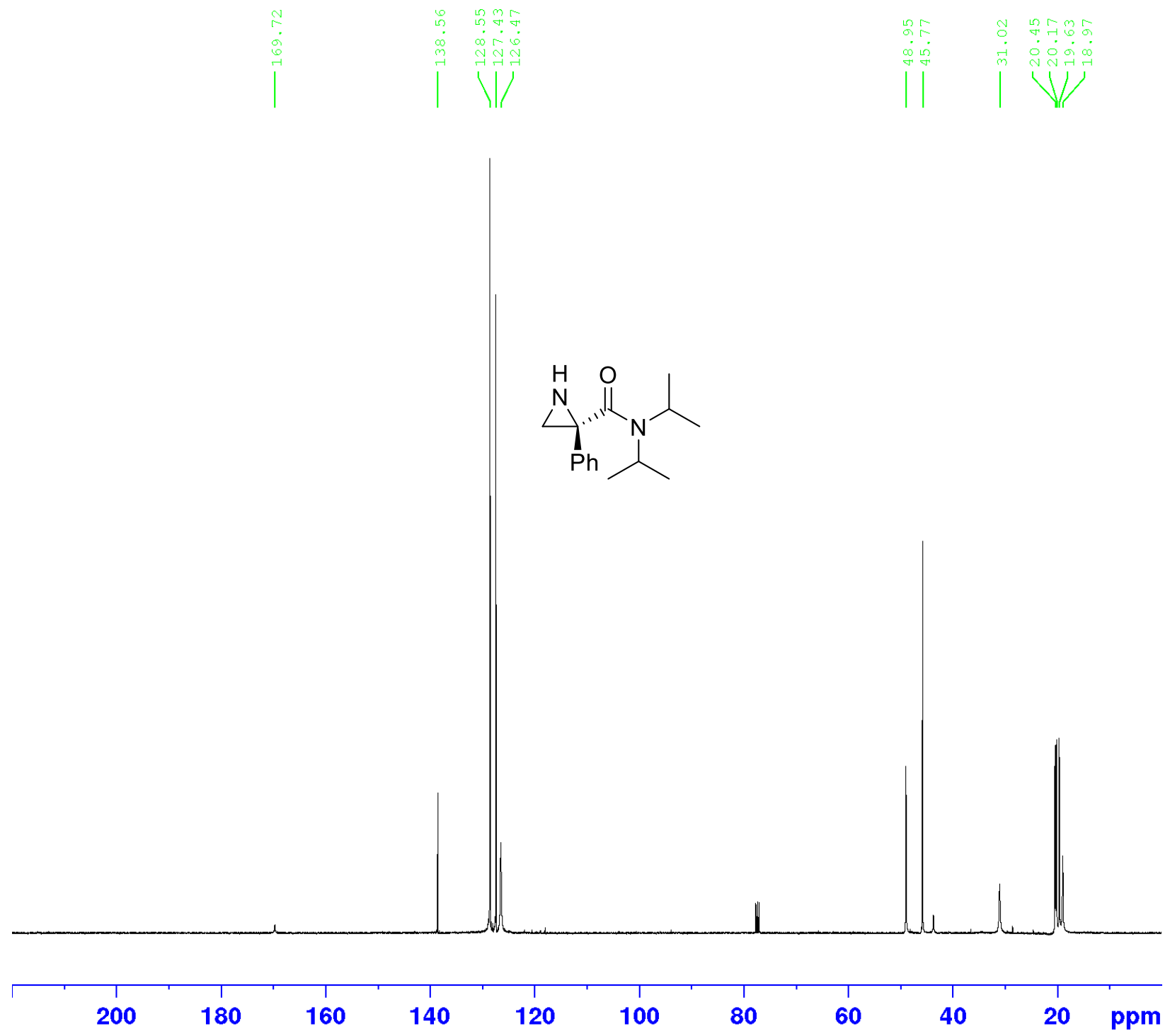


(35): ${ }^{1} \mathrm{H}$ NMR $(400 \mathrm{MHz})$ in $\mathrm{CDCl}_{3}$

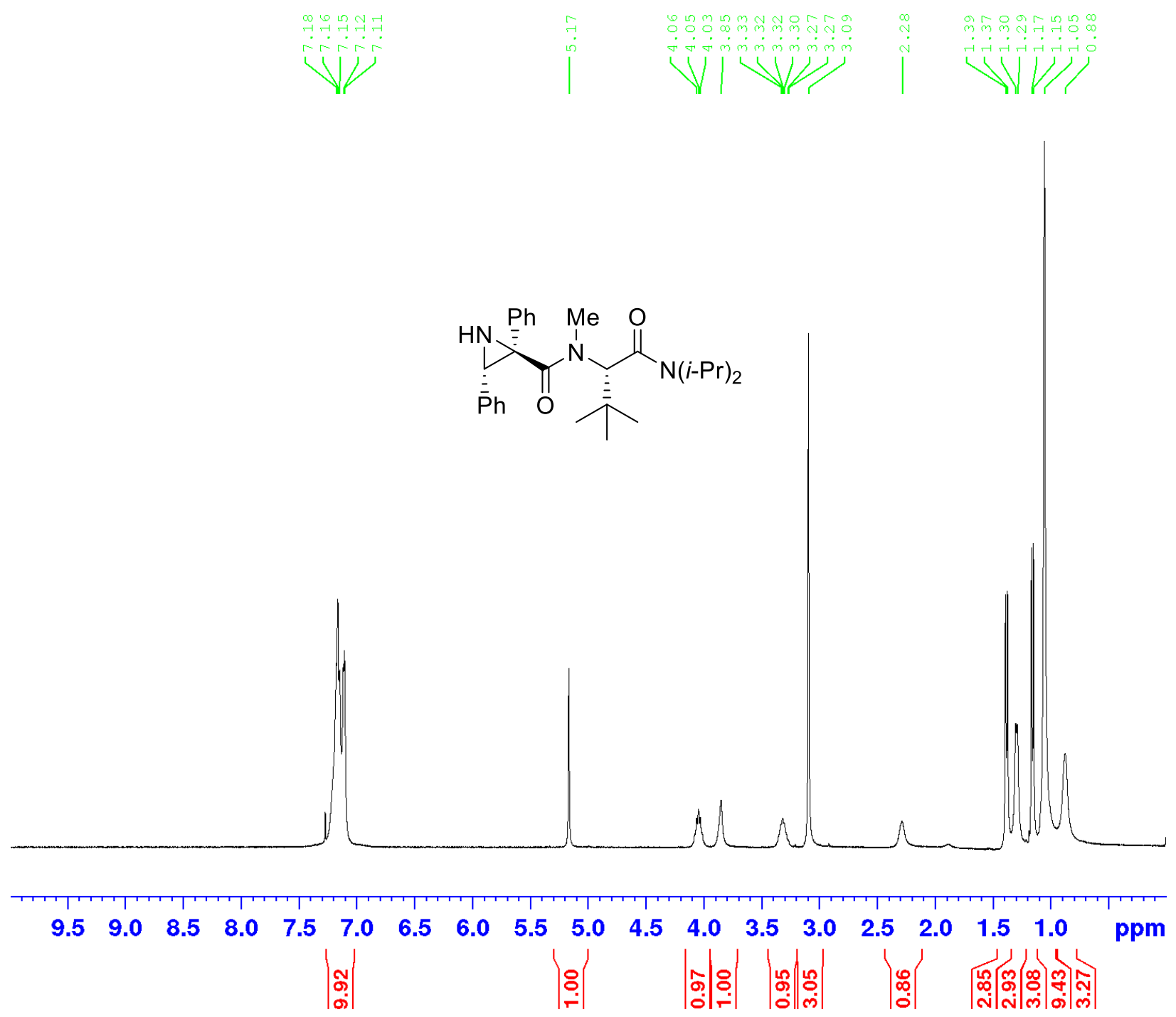


(35): ${ }^{13} \mathrm{C}$ NMR (100 MHz) in $\mathrm{CDCl}_{3}$

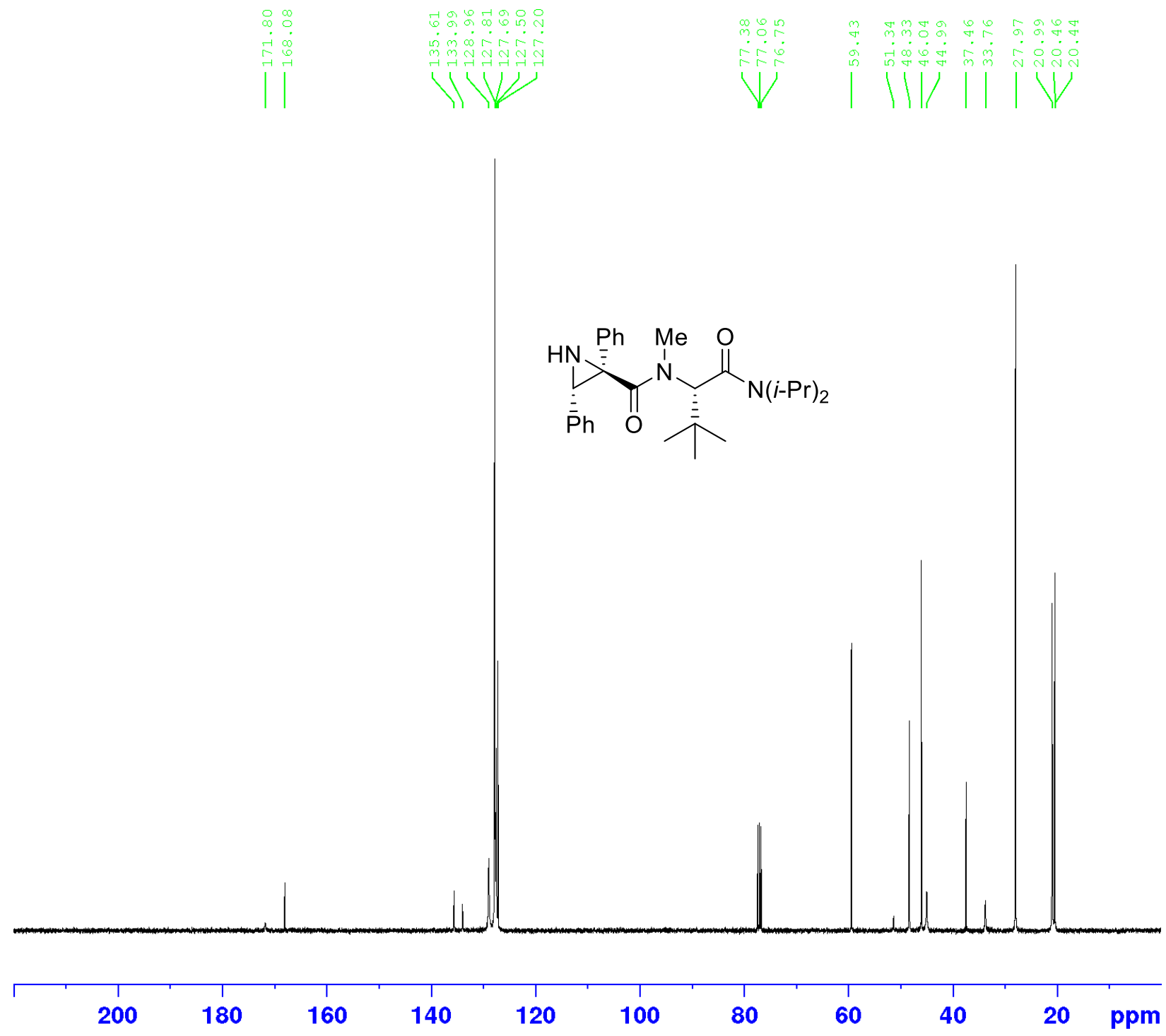


(36): ${ }^{1} \mathrm{H} \mathrm{NMR}(400 \mathrm{MHz})$ in $\mathrm{CDCl}_{3}$
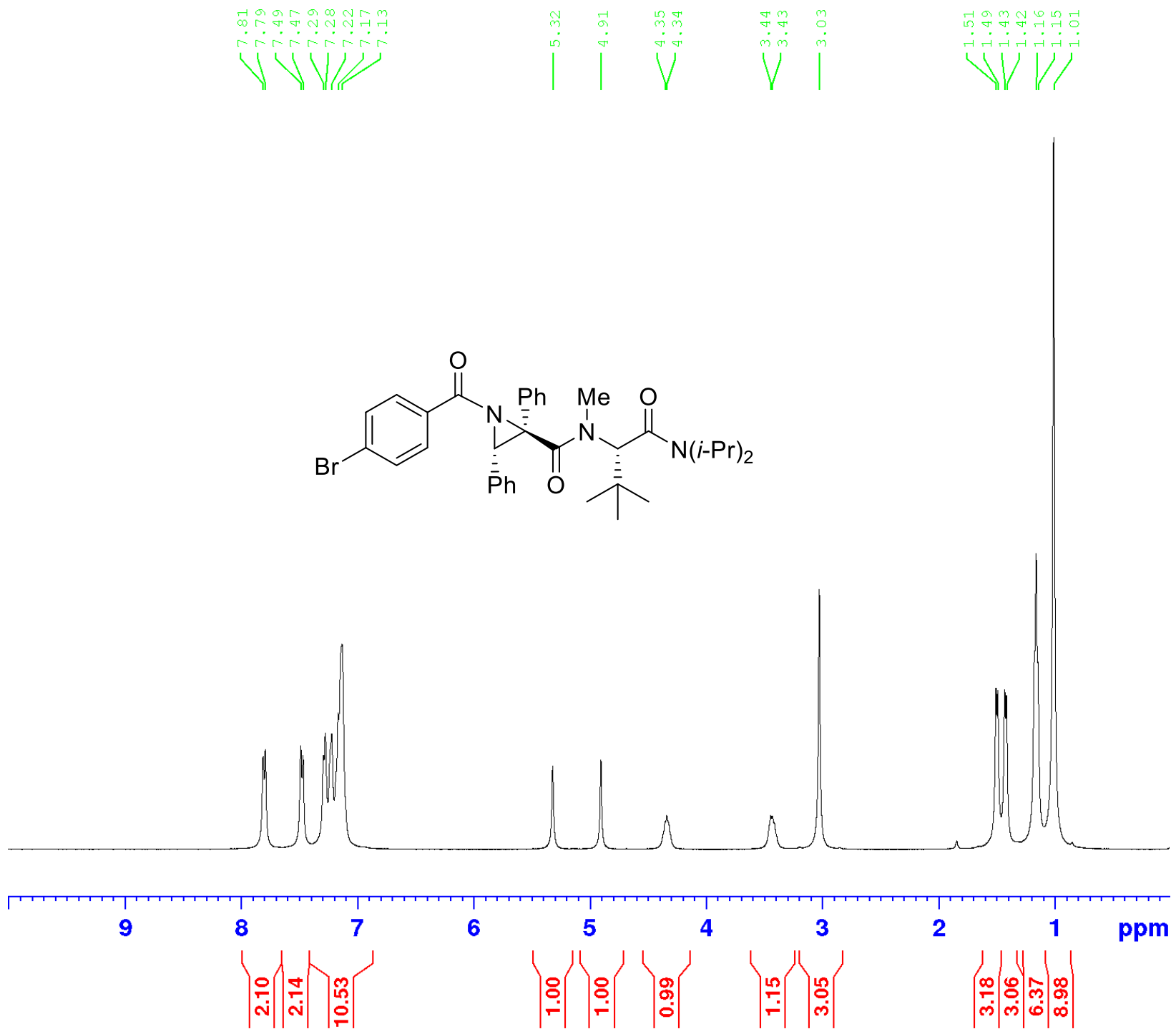
(36): ${ }^{13} \mathrm{C} \mathrm{NMR} \mathrm{(100} \mathrm{MHz)} \mathrm{in} \mathrm{CDCl}_{3}$

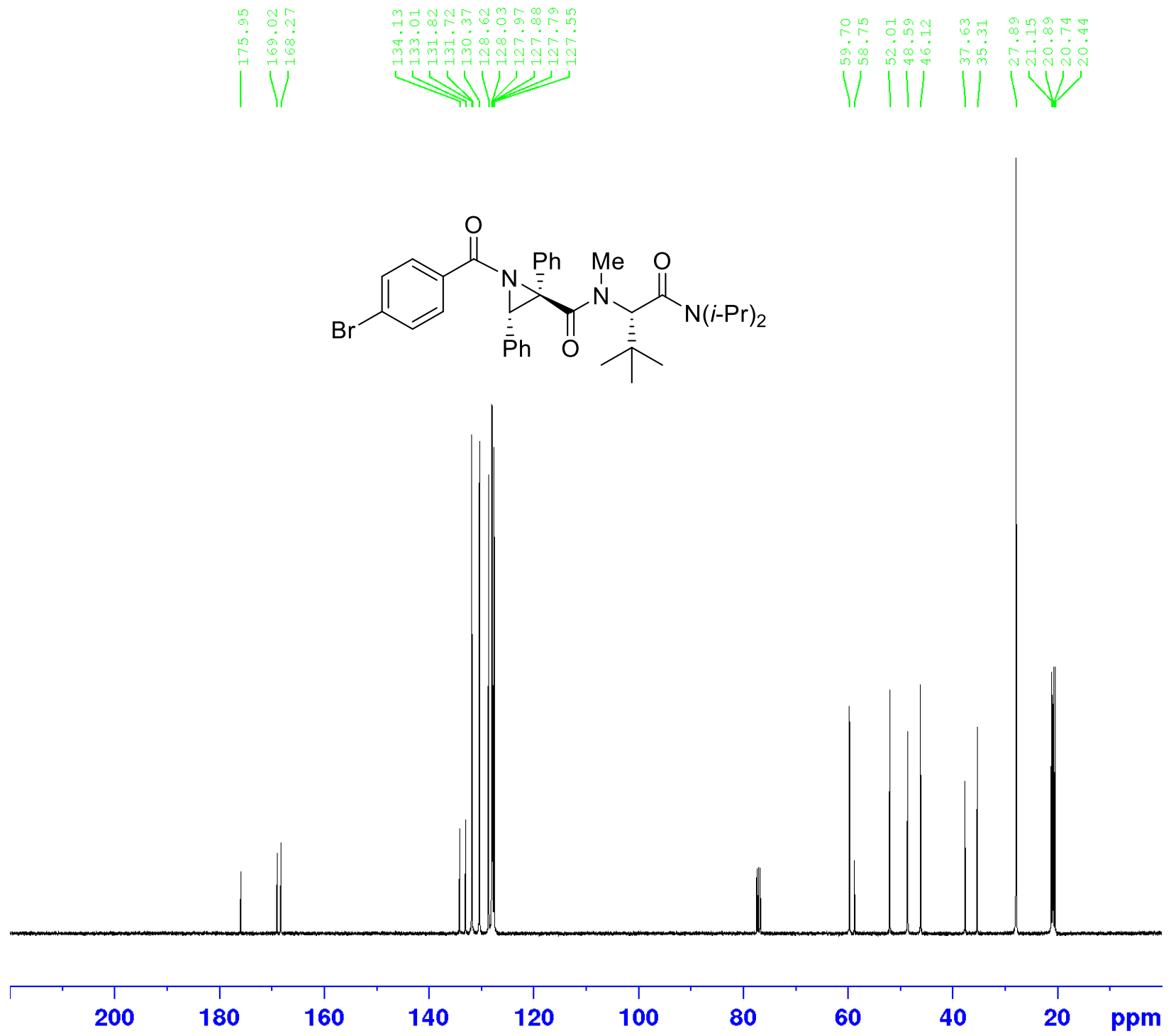

